UWS Academic Portal

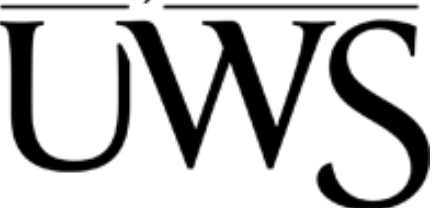

\title{
Developments of electric cars and fuel cell hydrogen electric cars
}

Awotwe, Tabbi Wilberforce; El-Hassan, Zaki; Khatib, F. N.; Al Makky, Ahmed; Baroutaji, Ahmad; Carton, James G.; Olabi, Abdul-Ghani

Published in:

International Journal of Hydrogen Energy

DOI:

10.1016/j.ijhydene.2017.07.054

Published: 05/10/2017

Document Version

Peer reviewed version

Link to publication on the UWS Academic Portal

Citation for published version (APA):

Awotwe, T. W., El-Hassan, Z., Khatib, F. N., Al Makky, A., Baroutaji, A., Carton, J. G., \& Olabi, A-G. (2017). Developments of electric cars and fuel cell hydrogen electric cars. International Journal of Hydrogen Energy, 42(40), 25695-25734. https://doi.org/10.1016/j.ijhydene.2017.07.054

\section{General rights}

Copyright and moral rights for the publications made accessible in the UWS Academic Portal are retained by the authors and/or other copyright owners and it is a condition of accessing publications that users recognise and abide by the legal requirements associated with these rights. 


\title{
Developments of Electric Cars And Fuel Cell Hydrogen Electric Cars
}

Tabbi Wilberforce ${ }^{1}$, Zaki El-Hassan ${ }^{1}$, F. N. Khatib ${ }^{1}$, Ahmed Al Makky ${ }^{1}$, Ahmad. Baroutaji ${ }^{2}$, James G. Carton $^{3}$,

Abdul G. Olabi ${ }^{1}$

1. Institute of Engineering and Energy Technologies, University of the West of Scotland, UK.

2. School of Engineering, Faculty of Science and Engineering, University of Wolverhampton, UK.

3. School of Mechanical \& Manufacturing Engineering, Dublin City University, Dublin, Ireland.

\begin{abstract}
The world continues to strive in the search for clean power sources to run the millions of different vehicles on the road on daily basis as they are the main contributors to toxic emissions releases from internal combustion engines to the atmosphere. These toxic emissions contribute to climate change and air pollution and impact negatively on people's health. Fuel cell devices are gradually replacing the internal combustion engines in the transport industry. Some notable challenges of the PEMFC technology are discussed in this paper. High costs, low durability and hydrogen storage problems are some of the major obstacles being examined in this investigation.

The paper explores the latest advances in electric cars technology and their design specifications. The study also compares the characteristics and the technologies of the three types of electric cars now available in the market.
\end{abstract}

Keywords: Electric Cars, PEM Fuel cell, Internal Combustion Engine, Hybrid Cars, Plug - In Hybrid cars, Battery Electric Vehicles

\section{Introduction}

A sustainable high quality of life is the basic driver for providing a clean, safe, reliable and secure energy supplies around the world. In order for human activities to co-exist with a sustainable environment, energy supply systems must provide some societal needs at affordable prices but at the same time they must not impact negatively on the environment. These systems need to mitigate the effects of climate change, reduce toxic pollutants and be in place to replace the diminishing reserves of oil. The implication of an energy system not being able to meet these requirements is an adverse effect on the environment, on the economy and on public health. 
Plans should be far advanced to promote more efficient use of energy and energy supply from a growing proportion of carbon free sources [1]. The impacts of climate change cannot be underestimated as they are irreversible. The world cannot take chances on this crucial decision, hence, the need for ideal emissions free future based on sustainable energy. One of the most promising ways to make this goal a reality is the usage of cleanly produced electricity from nonfossil fuels such hydrogen using fuel cells technology. Hydrogen is not considered a primary source of energy like coal and gas. It is a potential for clean energy but it is currently mainly produced using existing energy systems that are based on different conventional primary energy carriers and sources.

Renewable energy will be one of the most important sources for the future production of hydrogen, even more than in the present. Regenerative hydrogen and hydrogen produced from nuclear sources and fossil based energy conversion systems with capture and safe storage (sequestration) of $\mathrm{CO}_{2}$ emissions are almost completely carbon free energy pathways. Scientist all over the world are researching the use of renewable energy systems in the transport industry due to the continuing depletion of crude oil based energy resources and their impact on the environment which is accelerating climate change as a result of the continued burning of fossil fuels. Emissions from fuel cells are extremely low hence the increased interest in their use and increased efforts by scientists and researchers across the globe to improve their efficiency and reduce their costs.

Any electro-chemical device that transforms chemical energy of any fuel directly into electrical energy is called a fuel cell. One of the main characteristics of fuel cells is that the reactants are fed directly from external sources unlike batteries which store the reactants internally. The electrodes in fuel cells are also not consumed as often the case with batteries, irreversibly in a primary cell and reversibly in a secondary cell, and do not participate in the reaction. Fuel cells are already used to generate electricity in many applications including spacecraft and in stationary uses such as emergency power generators. Several research work in recent years has revealed that the transport industry is one of the main contributors to the emission of hazardous and toxic substances into the environment as they rely highly on fossil fuels and as explained earlier, they are the main reasons for the phenomena of global warming. This in effect has contributed massively to the sudden climatic changes around the globe and many of the released 
pollutants contribute to the depletion of the ozone layer. Due to the high demand for fossil fuel by the transport sector, there is continual diminution of fossil based resources of energy such as crude oil. The worlds total energy consumption is highly dominated by the transport industry which accounts for nearly 55\% of the world energy consumption and $30.9 \%$ of carbon dioxide gas emissions according to recent research studies [1]. It was also anticipated that if no proper action is collectively taken the situation will get worse and the negative impacts on the environment and world economies will further increase. Fig. 1 and Fig. 2 from Das et al [2] explain the levels of energy consumption by 2 sectors over the past few years. From Fig. 1 and Fig. 2 it is also possible to predict the likely events in the future if the situation is not carefully addressed. A possible solution to mitigate this challenge is the use of electric cars, a topic that is currently being investigated and explored as the alternative to the usage of fossil fuel. Electric cars are considered to be environmentally friendly and are predicted to aid in the process of reducing toxic emissions into the atmosphere. Most of the electric energy sources currently under consideration are from batteries, ultra-capacitors or fuel cells. Another advantage of using electric cars is the fact that they help in reducing operational cost compared to gas or oil powered vehicles.

\section{Energy consumption} (Survey and prediction)

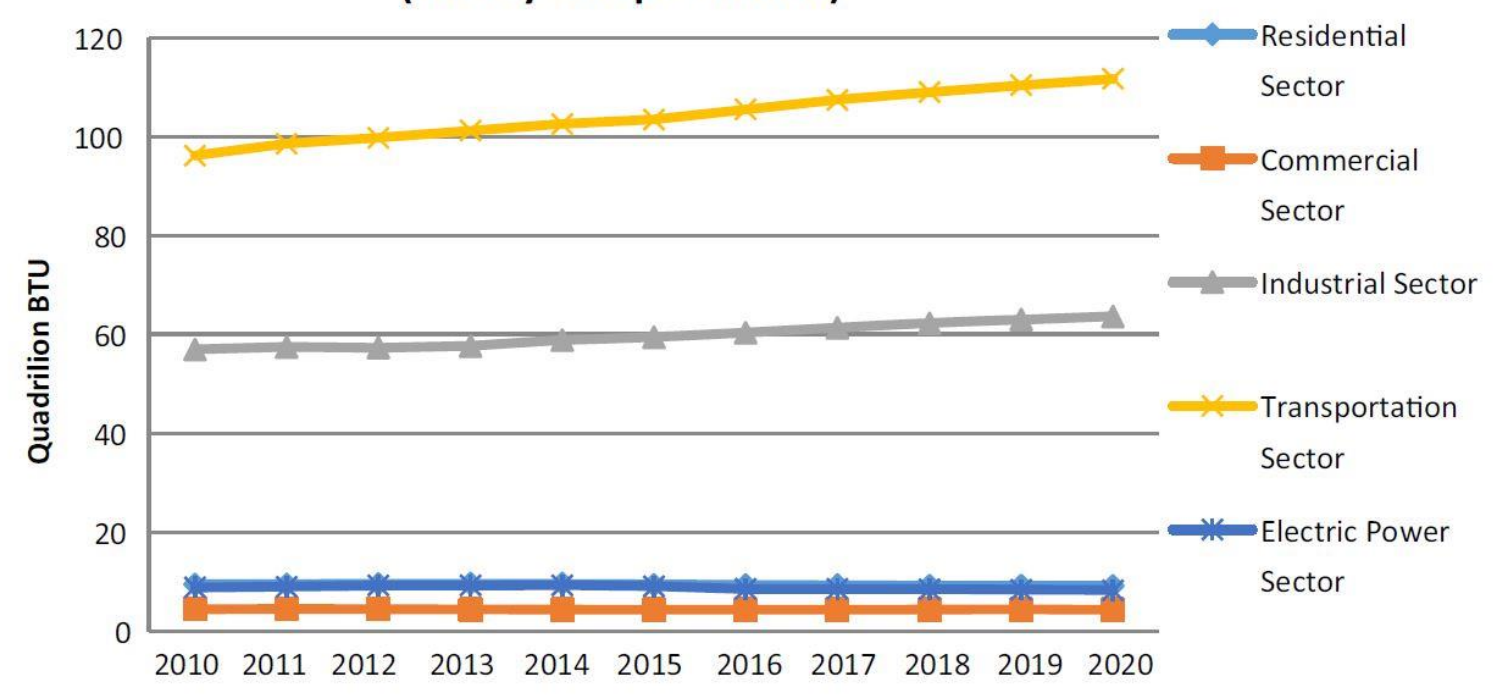

Fig. 1: Consumption of energy in different sectors [2] 


\section{Carbon Dioxide Emissions}

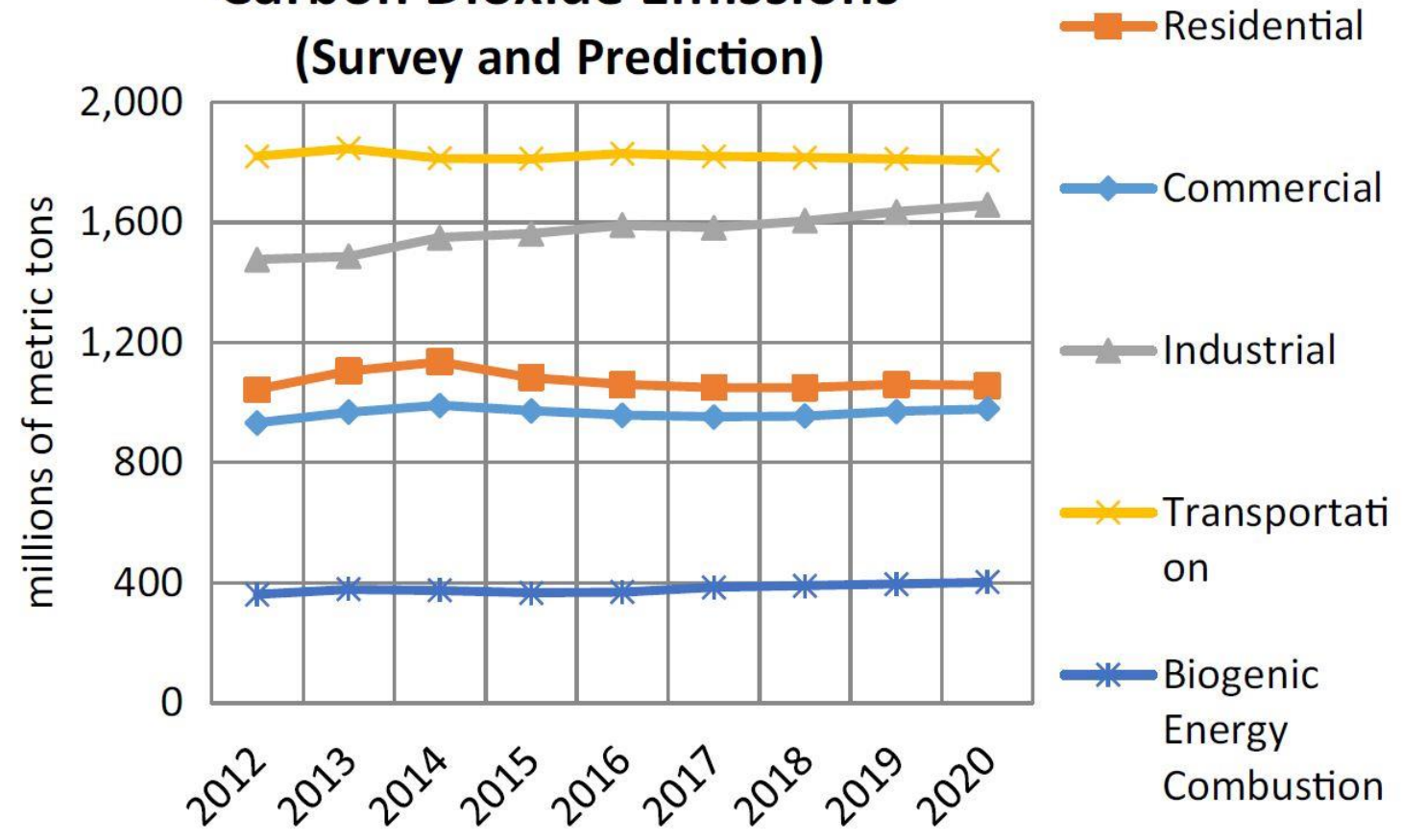

Fig. 2: Emission statistic of carbon dioxide statistics in different sectors [2]

It is estimated that electric vehicles cost nearly 2cents per mile while conventional petrol powered cars cost around 12 cents per mile indicating an extra 10 cent per mile needed in running a petrol powered vehicle. Recent studies have revealed that electric cars can operate within 4 - 8 miles per kWh energy with zero emission of greenhouse gases (GHG). The US Department of Energy also reported that internal combustion engines (ICE) vehicles normally use $15 \%$ of the total fuel energy to run the car while $75 \%$ of the energy is usefully utilized in electric vehicles [3, 4]. Most electric vehicles are quite expensive due to the cost of their source of energy that accounts for almost one third of the entire cost of the car. A number of energy storage mediums in electric cars are currently being considered with the express purpose of reducing the cost relating to energy storage and utilisation.

Electric cars are classified under three main categories. These include battery electric vehicles (BEVs), Fuel cell electric vehicles (FCHEVs) and hybrid electric vehicles (HEVs). Extensive research work has been carried out to analyse energy consumption and compare fuel types including alternative fuel cell systems which are shown to yield positive results [5]. This in effect will reduce the demand for oil consumption in the transport industry [6]. Vehicle emission 
problems can be solved using two approaches. The first method is to change the fuel type used which can be addressed by either enhancing the quality of conventional fuel or by using alternative fuel systems. The second alternative has to do with the engine technology which involves the reduction of in-use vehicles emissions and the new vehicles emissions standards. In parallel with these developments; the transport sector can have a positive effect on a viable ecodriving strategy and reduction of excess fuel consumption [7-9]. A representative tool was developed by Achour et al [10] for a local authority to help them identify the air quality issues caused by traffic emissions. Most of the outcomes of these investigations were applied in developed countries as the transport sector is going through some challenges. The concept of a fuel cell was developed by Sir William Groove in England in 1800s but the actual utilization of the concept only occurred in the 1950s when Nasa conducted extensive research work in the agency search for methods for generating power for space vehicles.

Fuel cells are often categorized according to the type of the electrolyte being used [11]. The proton exchange membrane fuel cell is the common type of fuel cells in use today. It is often made of a solid polymer as its electrolyte and a porous carbon electrodes containing platinum as its catalyst. The catalyst could also be an alloy. Hydrogen is supplied from an external source, kept in a tank or a reformer is used as its continuous fuel source. The membrane is made in such a way as to be only permeable to protons but not to electrons. There are instances where electrons could pass through the membrane leading to irreversibility and ohmic potential loss. The usual setup is for the electrons to pass through an external circuit. The cathode side on the other hand is designed as the region where the protons and electrons combine with oxygen to produce water which is expelled as the cell only waste product. The oxygen is often supplied to the fuel cell from the air or in a purified form. PEM fuel cells are often preferred for transportation applications and other stationary applications. This is simply because they have low operating temperatures, high power density, fast start-up, system robustness, flexibility of fuel type (with reformer) and reduced sealing, corrosion, shielding or leakage concerns [12]. Most buses and cars today are being designed to use PEM Fuel cells.

According to Alaswad et al [6], a large portion of the fuels used in heat engines are emitted as heat due to exhaust gas and friction losses. 
The shipment of fuel cell systems saw an appreciable increase in 2012 compared to the previous years. The total shipments made in 2012 were estimated to be 45,700 units of which the majority was for the transportation industry. A huge number of fuel cell electric vehicles (FCEV) were produced during this period. The IX35 FCEV was produced by Hyundai while Toyota produced the Mirai. This paper seeks to explore the usage of fuel cells in the car industry and some recent modification made in the technology and compare this with battery powered cars.

\section{General Composition of a Proton Exchange Membrane Fuel Cell}

PEM fuel cell was invented by Thomas Grubb and Leonard Niedrach at General Electric in the early 1960s [14]. The first assignment was to develop a small fuel cell for the U.S. Navy's Bureau of Ships (Electronics Division) and the U.S. Army Signal Corps [15]. The fuel cell was fueled by hydrogen generated by mixing water and lithium hydride. It was compact but the platinum catalyst was expensive. The initial idea was for NASA to develop a PEM fuel cell for Project Gemini in the early U.S. space program. Batteries were used for the preceding project mercury missions, but Project Apollo required a power source that would last a longer period of time. There were some challenges encountered during the manufacturing of the first PEM fuel cell. There were some internal cell contamination and leakage of oxygen through the membrane. General electric modified the design and concept which worked perfectly for the rest of the Gemini flights. The designers of Project Apollo and the space shuttle ultimately chose to use alkali fuel cells. The work by General Electric on fuel cell continued till the 1970s and designed the PEM water electrolysis technology, which led to the U.S Navy oxygen generating plant. The British royal navy used PEM fuel cells in the early 1980s for their submarine fleet. The last decade has seen PEM fuel cells being researched extensively and made remarkable strides particularly in the transport industry.

The polymer electrolyte also called proton exchange membrane (PEM) fuel cell delivers high power density while providing low weight, cost and volume. It is made up of a negatively charged electrode (anode), a positively charged electrode (cathode) and an electrolyte membrane as shown in Fig. 3. Hydrogen is oxidized on the anode and a reduction of oxygen occurs at the cathode. Protons are then moved from the anode to the cathode through the electrolyte membrane and the electrons are carried over an external load circuit. On the cathode, oxygen reacts with protons and electrons forming water and producing heat [16]. In PEM fuel cells, 
transport from fuel flow channels to the electrodes takes place through an electrically conductive carbon paper, which covers the electrolyte on both sides. The porosity of this backing layer is often 0.3 to 0.8 and functions as the medium for transporting the reactants and products to and from the bipolar plates to the reaction site [17]. An electrochemical oxidation reaction occurs at the anode producing electrons that flow through the bipolar plate often made of a metal or graphite and interconnect to the external circuit while the ions pass through the electrolyte to the opposing electrode. The electrons finally return from the external circuit while the ions pass through the electrolyte to the opposing electrode. The electrons return from the external circuit to participate in the electrochemical reduction reaction at the cathode. The reactions are shown in Eqns. 1-3:

Anode:

$$
H_{2}(g) \rightarrow 2 H^{+}(a q)+2 e^{-}
$$

Cathode:

$$
\frac{1}{2} O_{2}(g)+2 H^{+}(a q)+2 e^{+} \rightarrow H_{2} O(l)
$$

Overall:

$$
H_{2}(g)+\frac{1}{2} O_{2}(g) \rightarrow H_{2} O(l)
$$




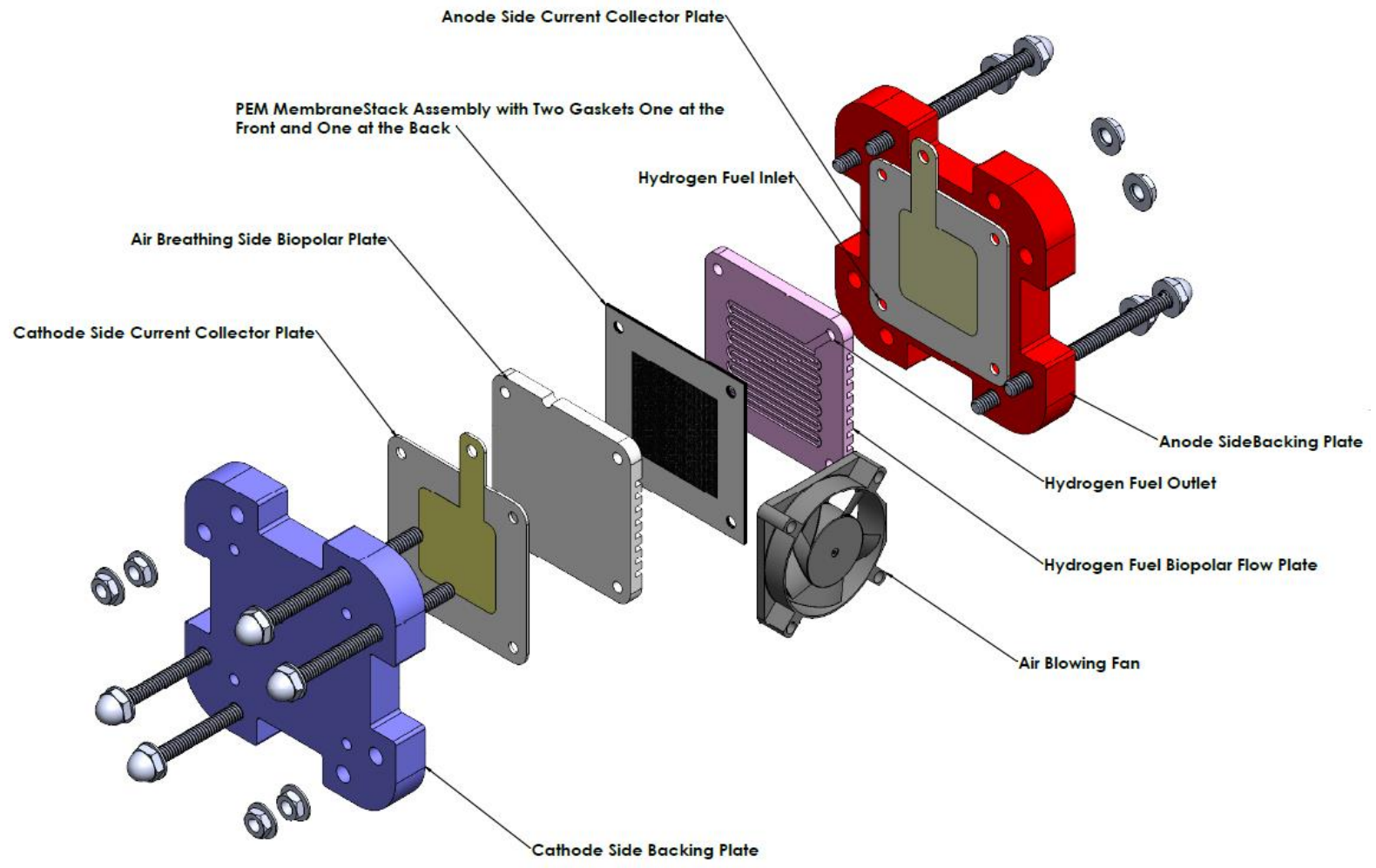

Fig. 3: The Polymer Electrolyte Membrane Fuel Cell (PEMFC)

Fluorinated Teflon based material manufactured by DuPont is the standard electrolyte material currently being used today in PEM fuel cells. It was produced for space applications in the 1960s. The DuPont electrolytes have the generic name Nafion and the types used most often are 1135, 115 and 117. The Nafion membranes are fully fluorinated polymers having high chemical and thermal stability. The electrodes are designed to be thin films bonded closely to the membrane. The electrodes with low platinum loading are believed to perform better than that with high platinum loading. A soluble form of the polymer is incorporated into the porosity of the carbon support structure to sometimes improve the utilization of the membrane. This increases the interface between the electro-catalyst and the solid polymer electrolyte [18-27]. 


\section{Fuel Cells in the Transport Industry}

One of the industries where fuel cell can play a critical role is the transport sector as explained earlier. This is simply because the transport sector accounts for $17 \%$ of the global greenhouse gas emissions yearly according to Cacciola et al [28]. There has to be serious adjustment made in this industry if the sector want to really meet the Kyoto protocol [29]. The industry intends to offer both significant reductions in harmful emissions as well as better energy conversion efficiencies. The world has seen a massive boost in the transport industry over the last few decades. There has been a surge in innovative, economic and environmentally friendly transport system worldwide. According to Dias et al [2], most vehicular systems are classified under three main categories: Internal combustion engine vehicles (ICEV), Hybrid electric cars and all electric cars. All electric cars utilize batteries, ultra-capacitors and fuel cells as their energy sources. The hybridization of ICEV and AEV gives rise to the hybrid system.

Fig. 4 shows the classification of cars while Eqn. 4 shows the hybridization factor which is the ratio of the electric motor $(\mathrm{EM})$ power to the total power $[30,31]$ :

$$
H_{F}=\frac{P_{E M}}{P_{E M}+P_{I C E}}
$$

Vehicles are classified into different types depending on the hybridization factor.

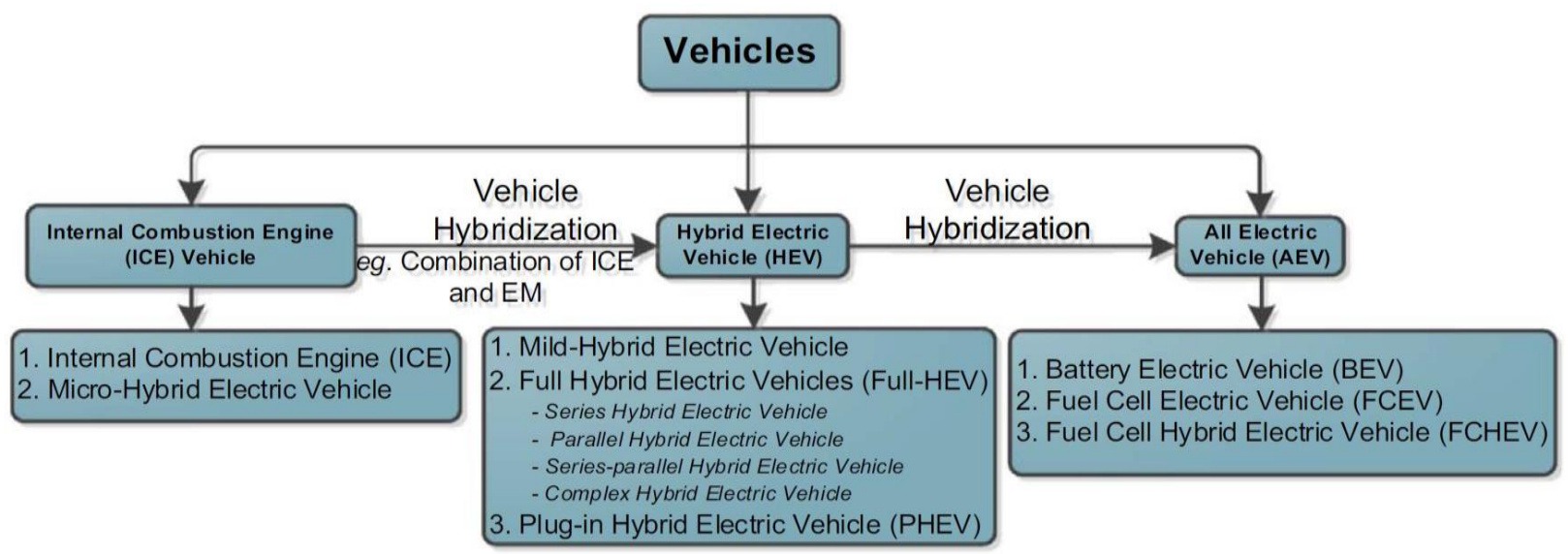

Fig. 4: Various classifications of a vehicle [2] 
$P_{E M}$ is the electric motor power and $P_{I C E}$ is the internal combustion engine power. Sharing the shaft for both the EM and ICE and also using a power split path are some ways hybridization of electric motor is done. Hybridization of vehicle results in improvements of fuel economy often expressed as mile per gallon (MPG) or miles per gallon gasoline equivalent (MPGe). MPGe is used for EV or PHEV where $33.7 \mathrm{kWh}$ electrical energy is same as the energy of one gallon of gasoline $[32,33]$. Internal combustion engine vehicle (ICEV) transforms chemical energy of fossil fuel into kinetic energy to run the car with the help of a combustion chamber. The byproduct of the reaction is heat which is released directly into the atmosphere. The world currently has two types of ICEV. These are conventional ICEV with no assisting electric motors and 2 micro HEV with low voltage EM incorporated with it. The conventional ICEV functions as stand-alone thus it has the lowest fuel economy but produces the most exhaust gas and heat that are toxic to the environment. The micro - HEVs uses electric motor of around $12-14 \mathrm{~V}$ providing power of around $5 \mathrm{~kW}$ with the ICE [34]. The internal combustion engine only uses the motor to start from cold start and does not play any active role in the car once it's in motion. This type of vehicle has the benefit of shutting down the ICE during coasting, braking or stopping which improves the fuel cell economy up to $5-15 \%$. The Citroen C3 is an example of micro - HEV produced by Citroen [35]. 


\section{Electric Vehicles}

It took over sixty years and six generations of gasoline engines for the Chevy Corvette to develop an electric car that can accelerate the speed to sixty mph within four seconds. The journey of developing electrical car engines from idea to market hasn't been an easy path. The poor performance of earlier electric cars developed led to the low patronage by users. Cost was also another determining factor that made people lose interest committing funds and resources in that venture. With the improvement of battery technology and automotive technology advancement over the last two decades, the new generation of high performance electric cars might soon become the latest choice of car for buyers around the globe. It is therefore clear that Electrical vehicles driven by energy stored in batteries or fuel cell units are the most likely option for reducing emissions from the transport sector. The world is generally coming up with lots of policies to encourage automobile industry manufacturers to shift their internal combustion engines to (EVs) [35]. This is because the world is doing everything possible to reduce emissions but boost regional economic development [36-39]. Hydrogen, Electric and Hybrid cars have been developed and demonstrated in several exhibitions. The future trends in green vehicle has been a subject of discussion in recent times. Major car makers have interest in developing future green vehicle markets. Green vehicles uses renewable energy sources as their main source of fuel. The current developments of green vehicles are listed in Table 1. These models were at developmental stages between 2009 and 2012. This publication seeks to explore the current technology status and potential developments of green vehicles are reviewed and the developments of the technology applications are thoroughly analysed to understand the move towards cleaner energy systems. 
Table 1: List of "green” vehicles released during 2009 - 2012 [40]

\begin{tabular}{|c|c|c|c|c|}
\hline Year & Battery Electric Vehicle & $\begin{array}{l}\text { Hybrid Electric } \\
\text { Vehicle }\end{array}$ & $\begin{array}{l}\text { Plug -in Hybrid } \\
\text { Vehicle }\end{array}$ & $\begin{array}{l}\text { Fuel Cell } \\
\text { Electric Vehicle }\end{array}$ \\
\hline \multirow[t]{4}{*}{2009} & Sabaru 4 seat & $\begin{array}{l}\text { Mercedes S400 } \\
\text { HEV }\end{array}$ & $\begin{array}{l}\text { Fisker Karma S } \\
\text { PHV }\end{array}$ & $\begin{array}{l}\text { Honda FCX } \\
\text { Clarity }\end{array}$ \\
\hline & Chrysler EV & & & $\begin{array}{l}\text { GM HydroGen3 } \\
\text { FCEV }\end{array}$ \\
\hline & Smart for Two EV & & & $\begin{array}{l}\text { Chevy Equimox } \\
\text { Fuel cell }\end{array}$ \\
\hline & ZENN city ZENN BEV & & & $\begin{array}{l}\text { Ford Fuel Cell } \\
\text { EV. }\end{array}$ \\
\hline \multirow[t]{7}{*}{2010} & $\begin{array}{l}\text { Chevy Volt Extended } \\
\text { Range BEV }\end{array}$ & $\begin{array}{l}\text { Ford Fusion } \\
\text { HEV }\end{array}$ & $\begin{array}{l}\text { Saturn VUE } \\
\text { PHV }\end{array}$ & \\
\hline & Chrysler EV & $\begin{array}{l}\text { Honda Insight } \\
\text { HEV }\end{array}$ & Toyota PHV & \\
\hline & Miles EV & $\begin{array}{l}\text { Hyndai-Kai } \\
\text { HEV }\end{array}$ & & \\
\hline & Mitsubishi iMiEV BEV & $\begin{array}{l}\text { Lexus HS 250h } \\
\mathrm{HEV}\end{array}$ & & \\
\hline & Nissan BEV & $\begin{array}{l}\text { Mercedes E } \\
\text { class HEV }\end{array}$ & & \\
\hline & $\begin{array}{l}\text { Ford Battery Electric } \\
\text { Van }\end{array}$ & $\begin{array}{l}\text { Porsche Caynne } \\
\text { S HEV }\end{array}$ & & \\
\hline & Tesla Roadster Sport EV & Prius HEV & & \\
\hline \multirow[t]{2}{*}{2011} & $\begin{array}{l}\text { BYD e6 Ford BEV } \\
\text { Small Car }\end{array}$ & & $\begin{array}{l}\text { BYD F3DM } \\
\text { PHV }\end{array}$ & \\
\hline & $\begin{array}{l}\text { Opel Ampera Extended } \\
\text { Range Battery Electric } \\
\text { Car }\end{array}$ & & Chevy Volt PHV & \\
\hline 2012 & Think Ox & & Ford PHV & \\
\hline
\end{tabular}


An alternative power source recently considered and still under intense investigation to replace or complement the internal combustion engine in recent times is Electricity. Hickman, 2009 [41] described the three types of electrically powered cars as pure -electrics (such as the Tesla): hybrids (the Prius) and plug - in hybrids (the Karma) [42]. Battery is often used by the pure electric to power the motor engine instead of petrol in the pure electrics. Pure electric cars that depend on battery as source of power have a range of 30-50 miles only. This clearly shows that it has some limitations in terms of range and lifetime though aid in the reduction of $\mathrm{CO}_{2}$ emissions. Hybrid vehicles are designed to use both an electric motor and an internal combustion engine. The battery often used in hybrid is small compared to that used in all - electrics. It also allows the vehicle to travel longer distance compared to the pure - electrics on one battery charge. Hybrids with plug in capabilities use a combination of grid electricity, regenerative energy from braking, and power from another on board source such as internal combustion engine or fuel cell. The engines can be designed to operate serially and applied to a variety of vehicles. The ideal scenario is to charge the plug in - hybrids electric vehicles at night during off peak grid use with power from renewable energies such as wind, solar and biomass. The Obama's administration stimulus Bill granted $\$ 14.4$ billion for plug - in hybrids. Electric cars are estimated to have about $35 \%$ of the car market by 2025 with $10 \%$ pure electric cars and $25 \%$ of hybrid cars according to Harrop and Das, 2009 [43].

In contrast to vehicles powered by a conventional fossil fuel or biofuel- based ICE, the energy storage system is of crucial importance for electric vehicles. As explained earlier using batteries to store electrical energy is one options for the manufacturing of electric cars. The other is the storage of energy in the form of hydrogen. The history of Electrical cars can be dated back years ago when Opel and General Motors first conceptualize the idea. General Motors first developed the world's first fuel cell EV called the GM Electrovan in 1966. The idea was revisited in the 1990s where the technology was revisited and reintroduced within the framework of a large scale development program. The work done during the development program led to the current HydroGen4 fuel cell car being manufactured. This is a mid - sized cross over vehicle based on the Chevrolet Equinox. The 1990s also experienced huge progress in the development of pure battery electric vehicles. These were mainly built to large scale project purposely for demonstrations. Example is the Opel Implus and the Rugen - Projekt [44]. It is also worth noting 
that mass - produced Electric Vehicles were designed and brought to the market on lease basis, namely the GM EV1.

The depletion of the fossil fuels resources and climatic change caused by anthropogenic $\mathrm{CO}_{2}$ emissions all contributed to the desire for electric cars to be commercialized. Most projects later carried out by Opel and GM in relation to this were actively supported by the GM Alternative Propulsion Centre Europe in Mainz-Kastel [45]

\section{Automotive Technology Development}

There are over 900 million vehicles worldwide on the road today. The fuel used for propulsion purposes for about $96 \%$ of these vehicles are produced from fossil fuel. It is estimated on record that this number of vehicles on the road is likely to increase appreciably to 1.1 billion vehicles by 2020 due to high economic expansion in China and India. This likely situation would have a detrimental effect on global crude oil demand and for the worldwide $\mathrm{CO} 2$ emissions. Since an increase in demand of oil and $\mathrm{CO} 2$ production proportional to the projected number of vehicles is not sustainable for financial, ecological and political reasons, every implementation strategy must aim at the replacement of fossil fuel as a source of energy for automotive applications. One strategy that was used by General Motors is the electrification of the automobile, the displacement of gasoline by alternative energy carriers as shown in Fig. 5. This will lead to a drastic reduction in fuel consumption, reduced emissions and also increased energy security through geographic diversification of the available energy sources. 


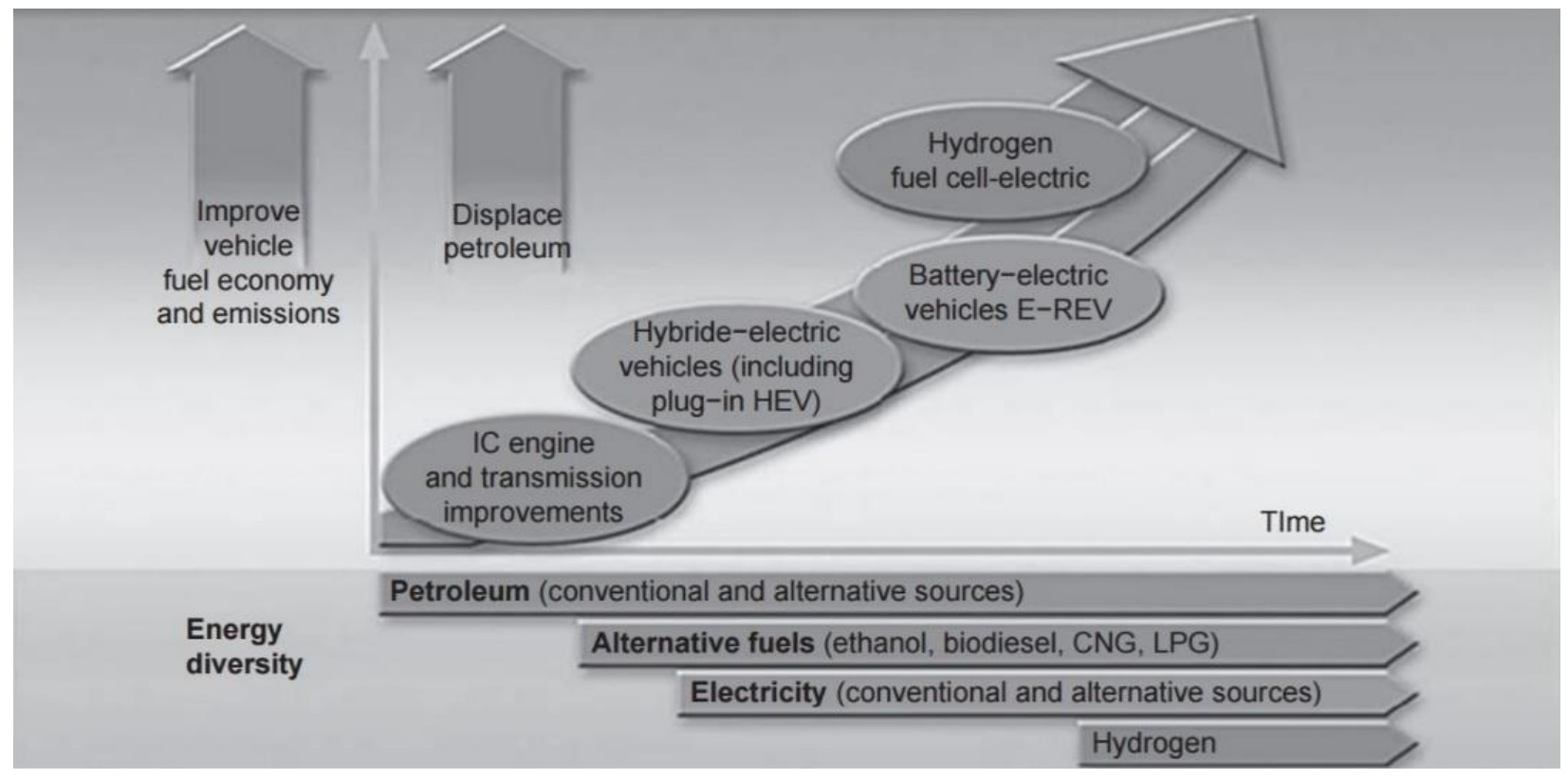

Fig. 5: GM's advance propulsion strategy [46]

This strategy was first established in 1996 during the development of the first electric vehicle GM EV1. This design was a pure battery electric vehicle (BEV) but failed to rise or compete on the market hence the need for its modification in the subsequent years. EV1 drivers coined the term range anxiety describing their omnipresent concern or the fear of becoming stranded with a discharged battery in a limited - range vehicle away from an electric infrastructure. These concerns remain one of the main challenges which still hinder the progress of the BEV on the market even till now. However, most of the EV - enabling electric components and systems have found utility in the meantime by adapting them for the usage in mild and fully hybrid electric vehicles (HEV's). These vehicles often do not provide power by exclusively using electric motor and therefore the power and energy level requirements for the system components are reduced in comparison with a conventional BEV. The conventional hybrid (both mild and full) improves vehicle efficiency thus reduces power generated from an onboard liquid medium. The onboard electrical engine and the storage system are only used to shift the operating point of the ICE to a more favourable point on the efficiency map and to enable recuperation. Thus, HEVs provide unfortunately not any additional pathways to utilize $\mathrm{CO}_{2}$-neutral renewable energy sources. Partially, these drawbacks may be resolved by introducing so-called extended-range electric vehicles (EREVs) that are discussed in the following sections. Zero-emission vehicles using an electric powertrain system based on hydrogen fuel cells or purely battery-electric systems that 
are fully competitive to conventional vehicles regarding performance and ease-of-use represent the ultimate target of the GM strategy as shown in Fig. 5. A further important step into this direction is the start of mass production of the Chevrolet Volt at the end of 2010, as well as the introduction of other vehicles like the Opel Ampera which are also based on the VOLTEC technology.

It is virtually impossible to discuss electric cars without considering the key role hydrogen might play in the whole process. As discussed in previous section, it is possible to use hydrogen as an on-board fuel for motive power either through internal combustion engine or fuel cell to generate electricity that can be used to power an electric traction motor. Hydrogen is often considered as $\mathrm{CO}_{2}$ - free energy if produced from renewable and nuclear energy. But with the latest technologies for hydrogen production, storage, transportation and distribution, as well as fuel cell emissions, if the hydrogen is from renewable energy sources, the hydrogen vehicle generates zero emission $\mathrm{CO}_{2}$, while plug-in hybrids are still not fully green since it is a hybrid model i.e. partially reducing emissions.

Within the public and also the automotive industry as well as the fuels community, very often the impression is created that an exclusive decision has to be made between FCE and BEV. This under normal circumstance shouldn't be a problem as the technological advancement plays different roles in the vehicle industry. This is due to the extremely different energy densities of the applied energy carriers as shown in Fig. 6. 


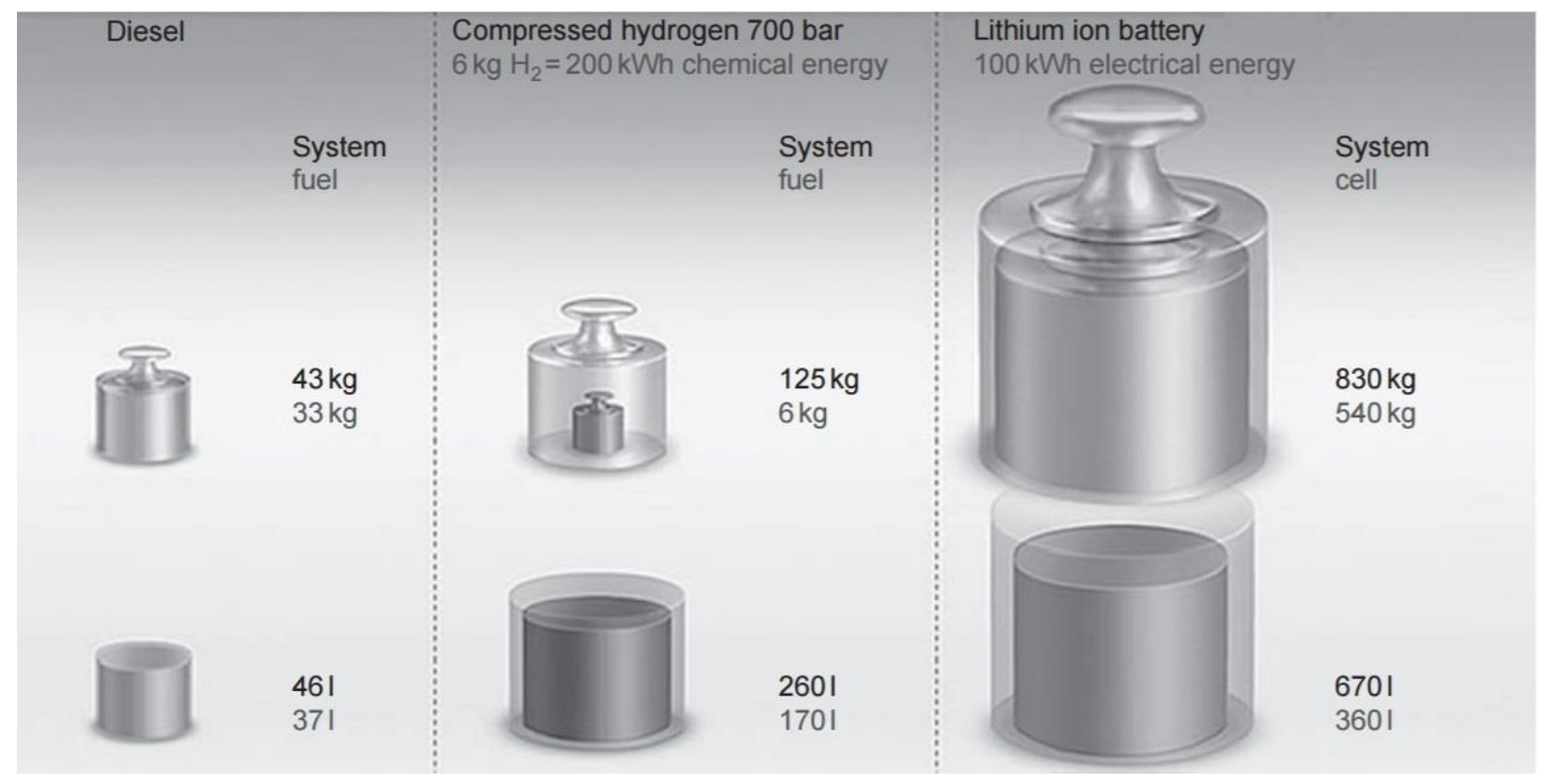

Fig. 6: Energy Storage System weight and volumes for various energy carriers [46].

According to Eberle and Rittmar [46], to realize a vehicle with a range of $500 \mathrm{~km}$, using today's technology, a tank system that weighs approximately $43 \mathrm{~kg}$ and requires a volume of just less than 50 litres is needed. They further explained that in order to build a zero emission vehicle depending on hydrogen as its fuel, the weight of the system to be built must be around $125 \mathrm{~kg}$ (based on a 700bar compressed gaseous hydrogen vessel). The energy storage gets even heavier if a future highly advanced lithium - ion (Li-ion) battery system (usable system energy density: $120 \mathrm{Wh} / \mathrm{kg}$, current technology is closer to $85 \mathrm{Wh} / \mathrm{kg}$ ) would be implemented as shown in Fig. 6. The weight of this energy system would be a little below a metric ton to provide a range of $500 \mathrm{~km}$. It is possible to refill a hydrogen tank within 3-5min, very similar to a conventional diesel tank. An example of a battery electric car is as shown in Fig. 7. In contrast, recharging a battery can take several hours depending on the battery size and infrastructure $(50 \mathrm{~kW}$ fast charging point) or even the whole day (Conventional 230V/16A electrical outlet). Some projections made indicate that a hydrogen tank system for a vehicle range of $500 \mathrm{~km}$ could be manufactured for approximately US\$ 3,000 at high volume production; on the other hand, a comparable $100 \mathrm{kWh}$ battery would cost approximately US\$50,000 [46]. 


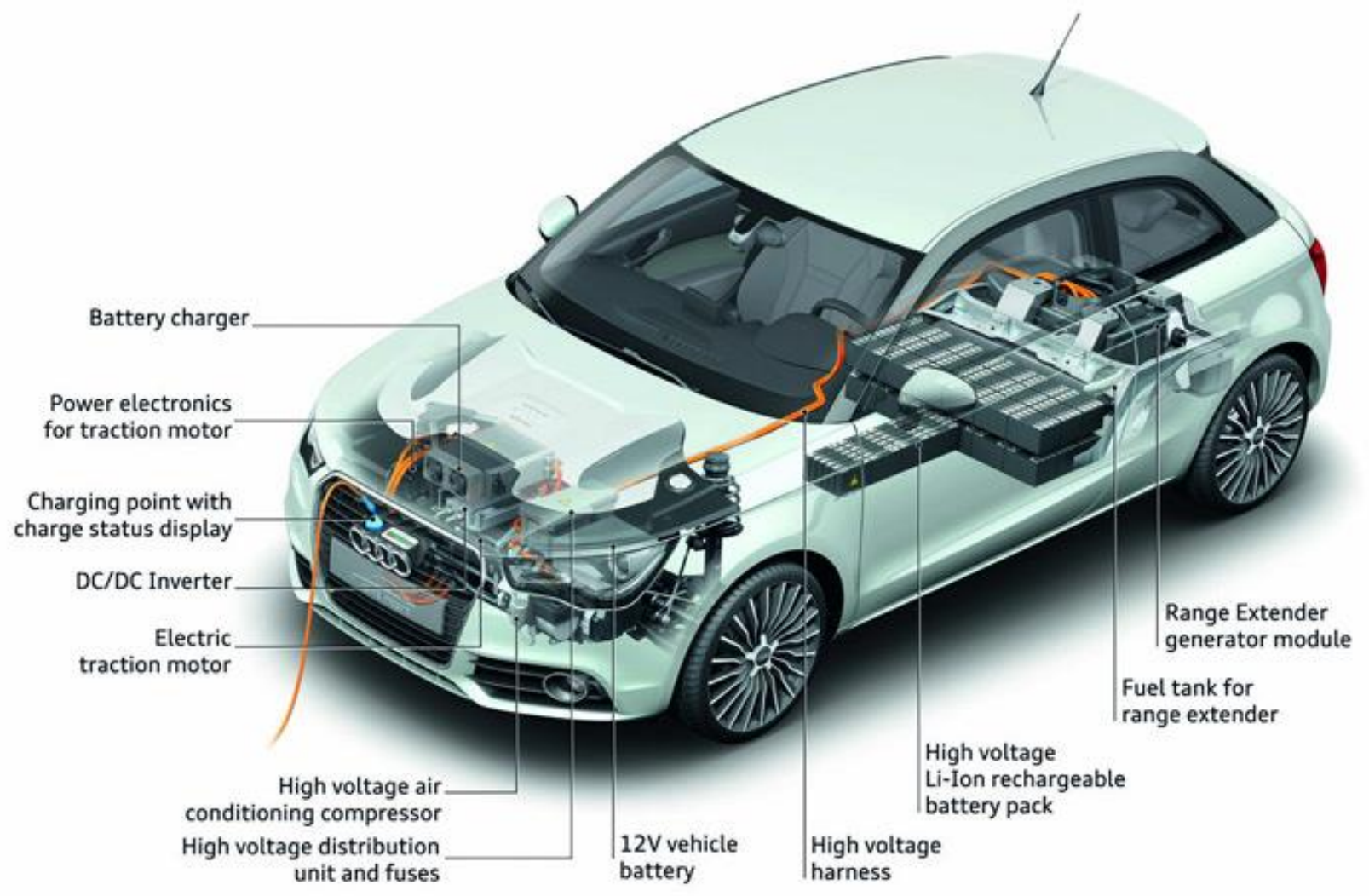

Fig. 7: Battery Charged Electric Cars [46].

The pure battery vehicle is best for urban use within ranges of up to $150 \mathrm{~km}$ as shown in Fig. 8 . The Chevrolet Volt and the Opel Ampera are best for customers who prefer smaller ranges not more than $500 \mathrm{~km}$. Some people may also prefer a small ICE for a small range a little beyond 60 $\mathrm{km}$ of pure EV operation. Hydrogen fuel cell vehicles having a high energy - density of $1600 \mathrm{Wh} / \mathrm{kg}$ of tank system weight makes them a suitable choice for the automobile industry. 


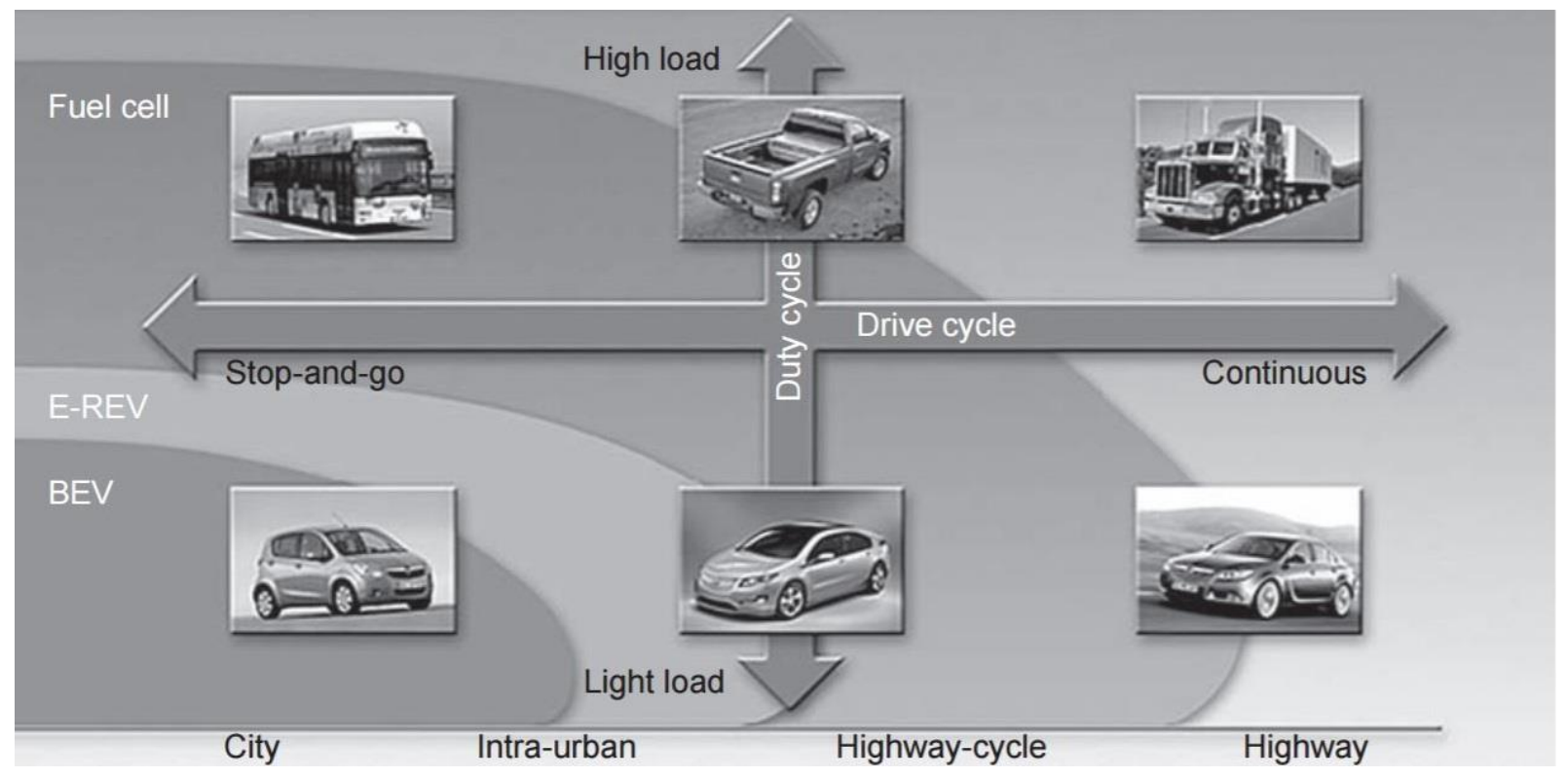

Fig. 8: Application map for various EV technologies [46]

\section{Battery Electric Vehicles (BEV) (all electric car)}

All electric cars are designed to use only battery to power the motor instead of petrol. They normally utilize electrical power for the vehicle propulsion. Six types of power transfer systems in all electric vehicles has been explained into details in literature [47]. They are classified into three sections: Battery Electric Vehicle (BEV), Fuel Cell Electric Vehicles (FCEV's) and Fuel cell hybrid electric vehicles (FCHEV's). There are similarities between the BEV and FCEV but FCHEV is different. The FCHEV involves hybridization of battery and fuel cell. The BEVs use energy storage systems while the FCEVs use fuel cells. The FCHEVs use both the fuel cell and energy storage system to power the vehicle. The battery electric vehicle is classified under the all-electric vehicles (AEV) which rely on battery as its primary energy source. The battery placed in the car gains its energy from the grid hence it is charged very often. The charging system is normally placed on board or off board. The mechanical drivetrain of this configuration is very low making it highly advantageous. This leads to the weight of the vehicle being very low hence loss from transforming energy from electrical to mechanical is very low. High torque traction motors for accelerating the vehicle is the main requirement for this type of configuration but also reduces the efficiency. High torque traction motors have high current flow in the armature winding, leading to heat loss in the motor [48 - 51]. Battery electric vehicles travel short distance and the speed is also limited making it conducive for stop and run driving 
situations. BEVs are best preferred for in-city driving due to their low mileage, low weight and low top speed. A modification of the vehicle power train is one approach to increase the vehicle driving range and top speed. An additional gear box in the vehicle is one effective way of getting this done. The function of the gear box is for the BEVs to run in both city and highway; however, this modification compromises the efficiency of the vehicle. BEVs without gear box (motor to wheel) has higher efficiency due to lower number of moving parts, has low rotational inertia and no energy loss in gear and differential mechanism [52]. The drivetrain schematic diagram of BEV is shown in Fig.9.

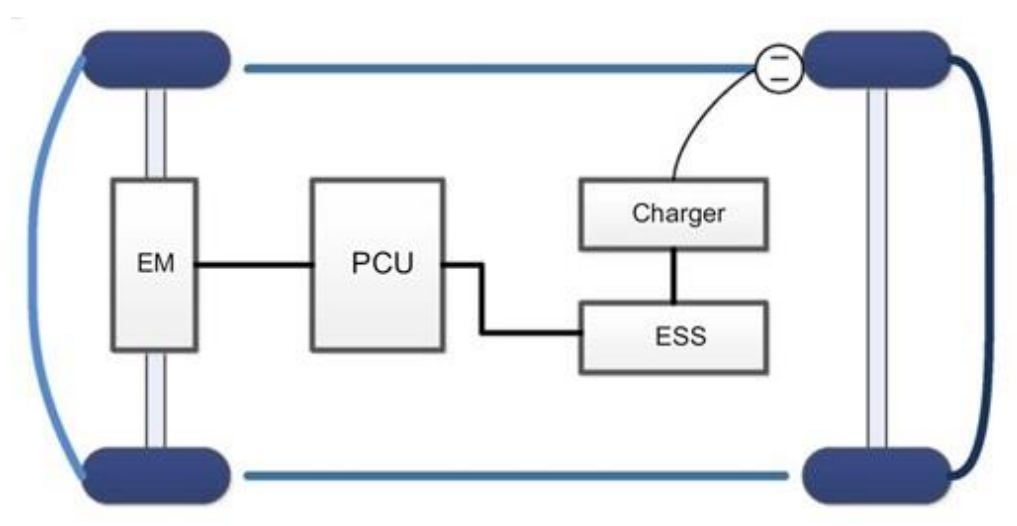

Fig. 9: Drive train schematic diagram of BEV's [2]

There are absolutely no tail-pipe emissions. They depend strictly only on batteries that are often recharged from the grid or by regenerative braking (utilizing brake energy as fuel). The old battery technology is less efficient compared to the recent lithium - ion batteries. Many car makers have applied this better battery technology in their electric powered cars. Tesla is the first powered lithium battery car. It is a pure electric roadster vehicle. This magnificent edifice was first unveiled to the public in 2006 but by 2009 a profit margin of nearly $5 \%$ was being made by the company [53]. The Tesla can travel a distance of 244 miles on lithium - cobalt battery pack and is able to accelerate to $60 \mathrm{mph}$ in 4 seconds. This explains how its performance is relatively high compared to other electric vehicles as shown in Fig. 10. 


\section{PLUG-IN ELECTRIC VEHICLES}

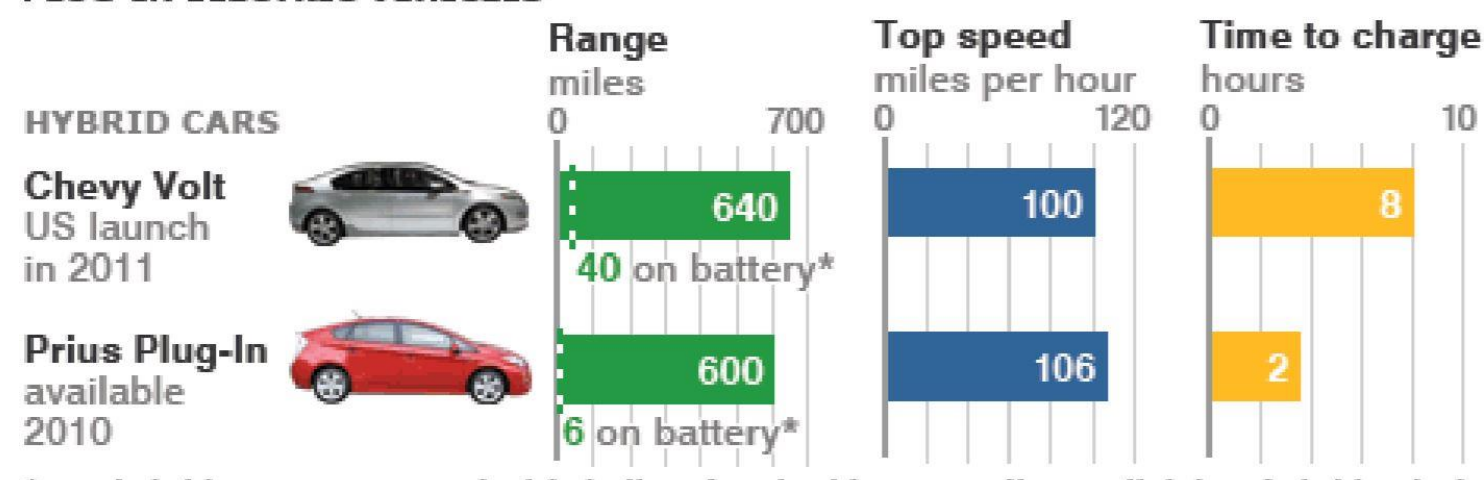

*new hybrid cars run on an electric battery for short journeys, then switch to a hybrid petrol mode for longer distances

\section{ELECTRIC CARS}

Tesla

Roadster

available

in US

Mini E

no launch

date

Th!nk City

available

in Norway

and Denmark

G-Wiz L-ion

available

in UK

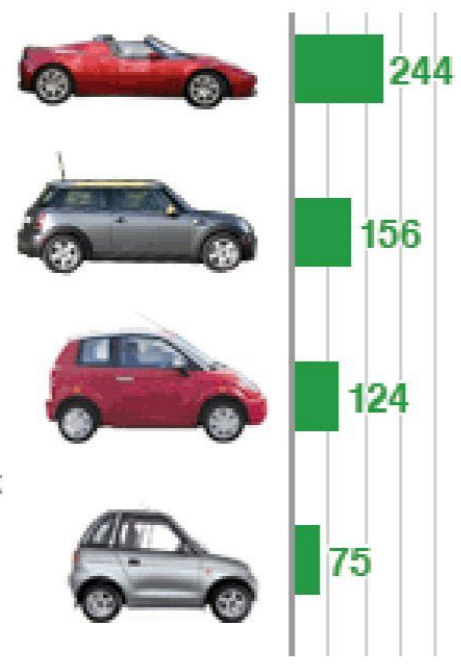

244

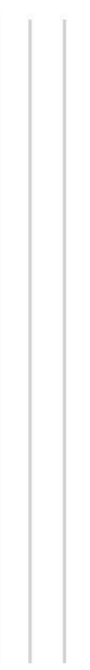

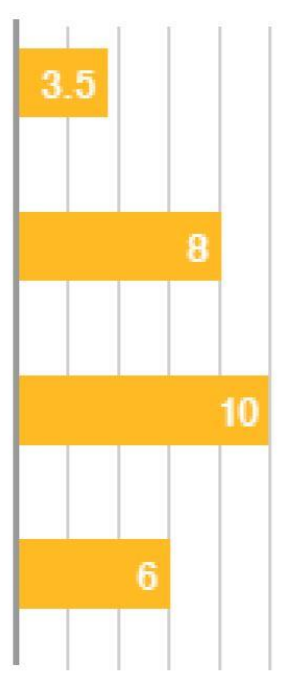

Fig. 10: Performance of some electric vehicles as of 2009 [54]

The high level of redundancy and multiple layers of battery protection in the Tesla roadster proved safe to be used in cars. The battery pack of the Tesla is 900 pounds in weight and there is a cooling system to constantly keep the lithium battery at optimum temperature. In 2011 , the group received a US government loan guarantees and huge collaborations with the German auto manufacturer Daimler to produce a pure electric Sedan. As of 2009 the Sedan model was nearly $\$ 49,000$ which was less than the Tesla roadster $(\$ 109,000)$ but very speedy. Tesla has made remarkable progress between 2009 and 2016. Today prices for Tesla cars vary between $\$ 80,000$ $-1,300,000$ depending on the size of the battery and the model. The company currently produces model $\mathrm{S}$ and model $\mathrm{X}$. The model $\mathrm{S}$ as shown in Fig. 11 and Fig. 12 is designed to accelerate 
from $0-60 \mathrm{mph}$ in as little as 2.5 seconds. It also comes with autopilot capabilities designed to make highway driving safer and stress free.

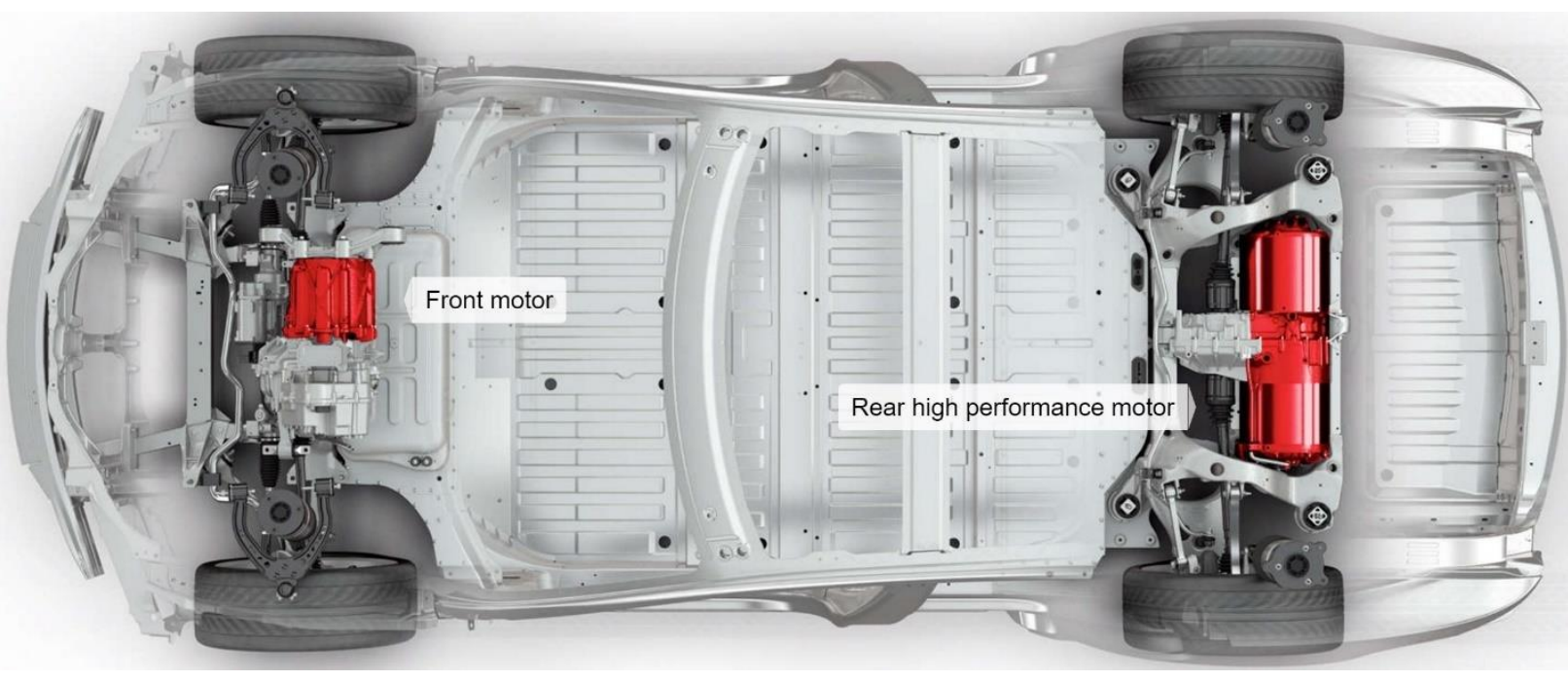

Fig. 11: Tesla newly designed car showing the chassis [55]

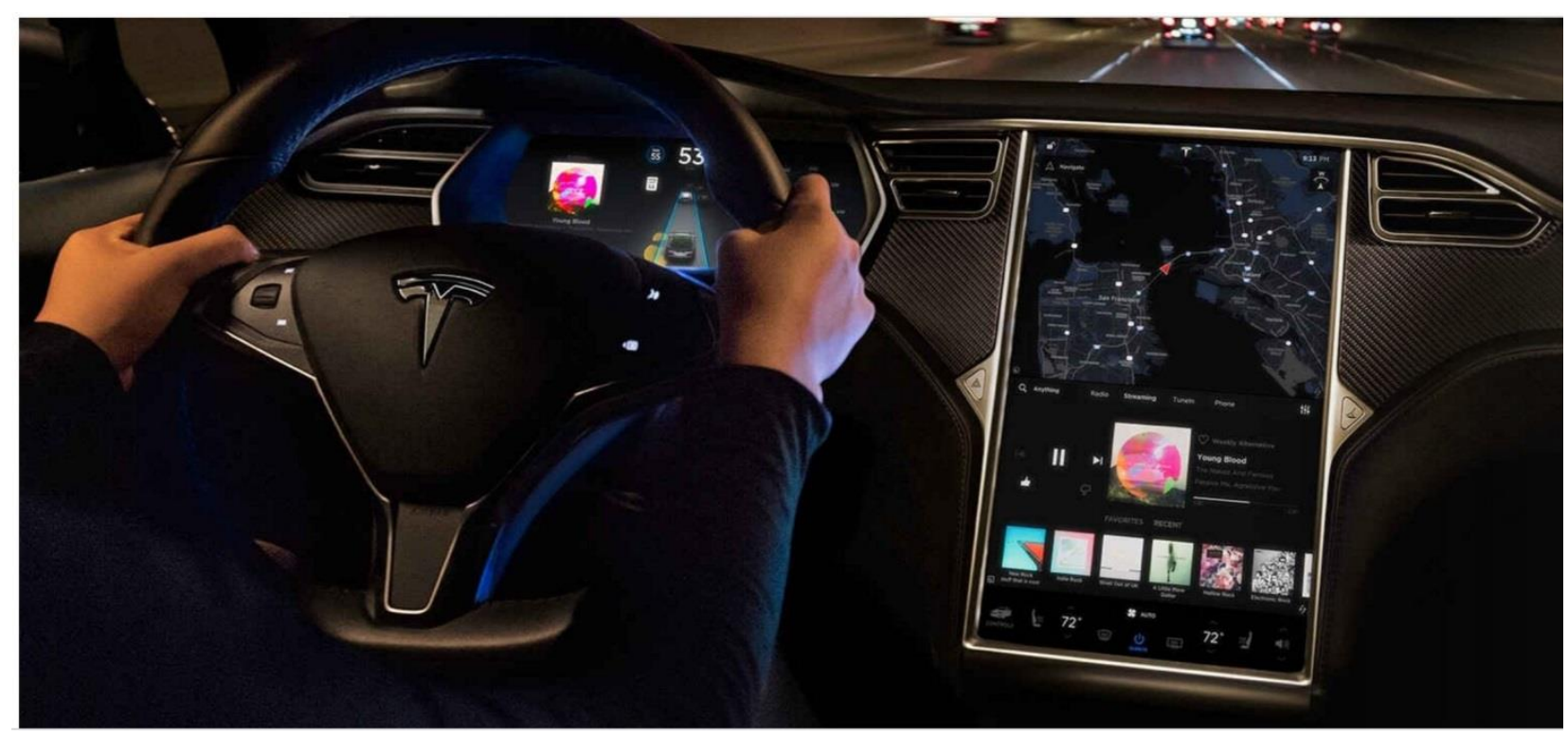

Fig. 12: Interior view of Tesla Model S [55].

It has $11 \mathrm{~kW}$ capable on - board charger ( 1 - phase $32 \mathrm{~A}, 3$ - Phase 16A). It can be upgraded and comes with a $7.4 \mathrm{~kW}$ cable blue industrial adapter $(230 \mathrm{~V}, 32 \mathrm{~A})$ and $2.3 \mathrm{~kW}$ capable 3 - pin domestic adapter [55]. 
While Tesla keeps upgrading their technology further, other automobile manufacturers like Coda Automotive has also been on the market since 2010. They first produced the all-electric Coda Sedan during that year. The vehicle features a $33.8 \mathrm{~K}, 333 \mathrm{~V}$ lithium ion battery pack with a warranty of 8 years and for 100,000 miles. The battery that was to be used was supplied by a Chinese company called Tianjin Lishen Battery. They are one of the largest producers of lithium batteries around the world. The Sedan produced by Coda Automotive took six hours to charge and delivered within a range of $90-120$ miles with a top speed of $80 \mathrm{mph}$. A target of 2,700 was set to enter the automobile industry by 2010 and 20,000 was anticipated to be on the market before the close of 2011 . The price was also fixed at $\$ 45,000$ before a federal tax incentive of $\$ 7,500$ and any other state incentives [56].

Lately in Europe, electric vehicles are making serious strides. Today there are several two seater $\mathrm{G}-\mathrm{Wiz}$ in the streets of London. G-Wiz electric cars are seen as an electronic quadricycle and use is encouraged with the exemption of parking fees and London city congestion charge. According to Moulson and Moore [61], Boris Johnson, the then Mayor for London seeing the importance of electric cars launched a plan to get 100,000 electric cars on the streets of London by 2015 and create 25,000 charging stations within that same period. This goal initially looked impossible but by 2015 there were more electric cars introduced in London with several charging centres scattered within one of the most industrial cities in the world, London. The Indians also designed their own type of the $\mathrm{G}$ - Wiz which was called the REVA produced by the REVA Electric Car Co. (RECC) for city car use. The company was based in Bangalore, India which is one of the world leading electric car companies. The work was actually a joint programme between California AEV and Maini Group in India. As far back 2006, the company received \$20 million from Global Environment fund and venture capitalist Draper Fisher Jurvetson. The company had sold nearly 1800 vehicles during 2009 but increased its production appreciably to over 30,000 units currently [56].

For a speed of $100 \mathrm{~km} / \mathrm{h}$ and a range of 120 miles, the "Th!nk City" was manufactured which is another fun loving electric vehicle. It is part of the two crash tested and highway certified cars in the world. The main manufacturer Think Global was formed in Pivco in 1991 in Oslo. The first practical prototype, PIV2 was built around a chassis made of aluminium and carrying a body of polyethylene thermoplastic. The battery technology is $\mathrm{Ni}-\mathrm{cd}$. Due to financial challenges in 
1999, the development of the production model was brought to a halt. Ford then took over the company to initialize the development of the Th!nk City but also sold the company in 2003 to KamKopr Microelectronics of Switzerland. The development model was again halted but due to some policies by the Norwegian government on the usage of electric cars, used Th!nk cars from the US and the UK were been re - exported to Norway to meet the high demand for electric cars. Some favourable policies initiated by the Norwegian government to support the usage of electric cars are: they are exempt from taxes, have free parking and free pass toll and even allowed to use bus lanes during rush hours to reduce traffic congestion. Inspire, a Norwegian Investment group acquired the company in 2006 and renamed it the Th!nk Global. With partnership with General Electric and Battery manufacturer A123 Systems, a new vehicle, the five seat, $130 \mathrm{~km} / \mathrm{h}$ Th!nk Ox model, was unveiled in 2008. According to Forbes.com, in 2009 a Finish Valmet Automotive company invested 3 million euros to commence the development of Th!nk electric cars. These cars are very commonly found in Norway, Denmark, Sweden, UK, Germany, Spain, Italy and Netherlands [56].

The Chinese company BYD CO in 2009 at the North American International Auto show (NAIAS) exhibited an electric car E6 which had a driving range of 250 miles got lots of attention from the media and the general public. The company was able to produce its own lithium-ion battery R\&D over 10 years. The main battery technology can be used in all the three types of electric vehicles. The battery was designed to have a life time of 10 years and can be charged to $50 \%$ of its capabilities within 10 minutes. 


\section{Hybrid Cars}

The problem with most electric cars is that their range is limited to no more than a few hundreds of miles with the most advanced Tesla Roadster. Batteries that are a bit efficient can only extend the range and reduce the charging times but the major problem is that these batteries have very limited life cycle. The solution to a hybrid car challenge as shown in Fig. 13 according to Harrop and Dros [43] is to direct the electric power from the generator to either the electric motor or the batteries depending on the state of charge of the battery and the power demand of the wheels. Toyota's hybrid car Prius still remain a popular car due to its high gas mileage. The car is powered by a battery for the first few miles. When the battery runs out, a conventional petrol engine takes over. Prius was anticipated to deliver up to 50 miles per gallon while Honda's Insight delivers $40-43$ miles per gallon at a cost about $\$ 3000$ less than the Prius.

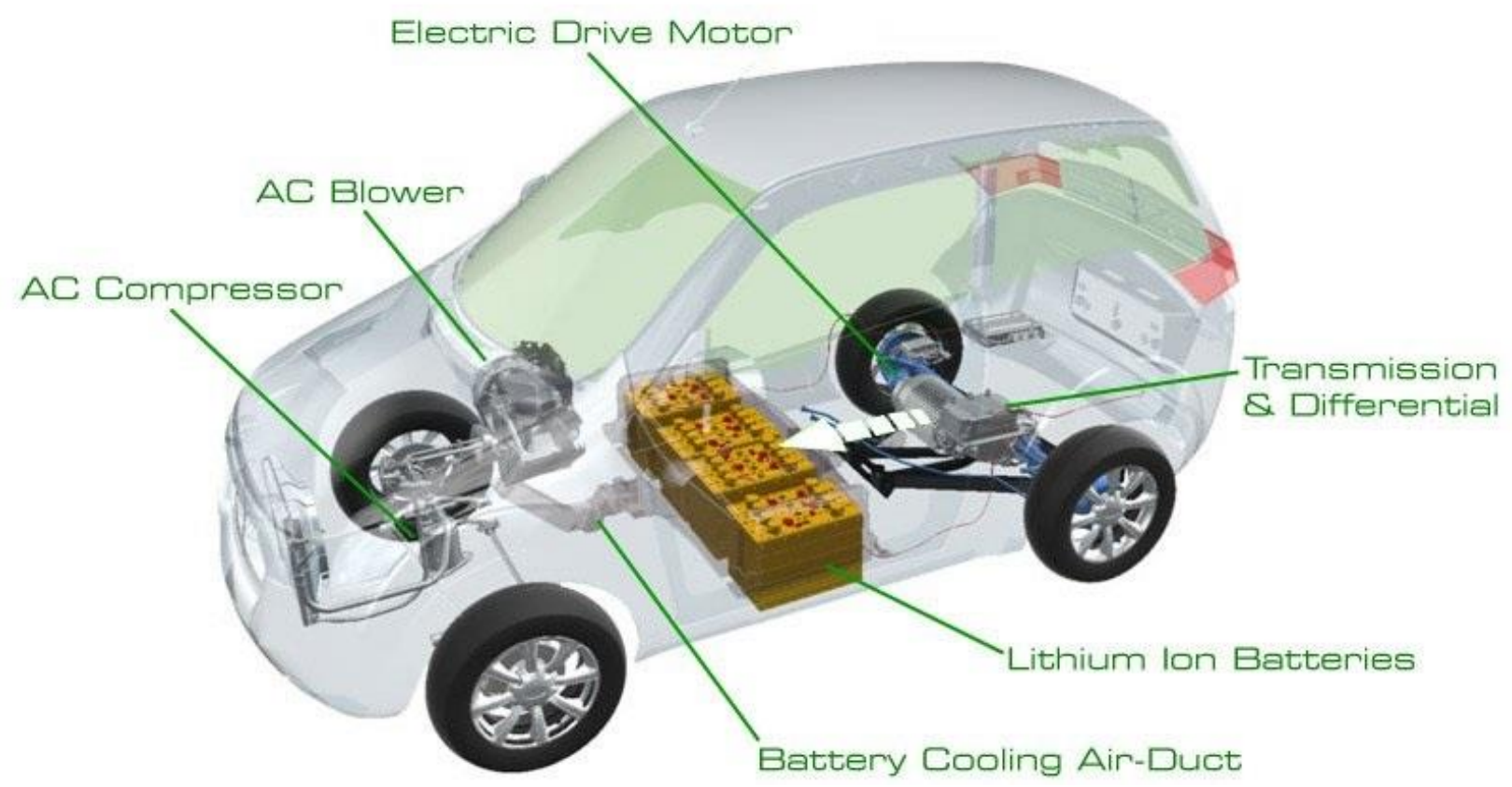

Fig. 13: Hybrid Electric car [43].

Today Toyota has developed a number of hybrid cars. Some of them are the Yaris Hybrid which has an engine of 1.5 litres hybrid e - CVT, fuel consumption of up to $85.6 \mathrm{mpg}, 5$ door hatch back, $\mathrm{CO}_{2}$ emissions of $75 \mathrm{~g} / \mathrm{km}$ and priced at 15,815 pounds. Others like the Auris hybrid also have an engine of 1.8 litres e - CVT, fuel consumption of $83.08 \mathrm{mpg}, 5$ door hatch-back, $\mathrm{CO}_{2}$ emissions of $79 \mathrm{~g} / \mathrm{km}$ and being sold for 20,895 pounds. There is also a RAV4Hybrid which has 
a 2.5 litre petrol hybrid e - CVT, fuel consumption combine up to $57.6 \mathrm{mpg}$, compact $\mathrm{SUV}, \mathrm{CO}_{2}$ emission of $115 \mathrm{~g} / \mathrm{km}$ and sold at 28,530 pounds. The initial hybrid car which is the Prius has also seen some modification. The latest design has an engine of 1.8 litre hybrid e - CVT, fuel consumption of up to $94.1 \mathrm{mpg}, 5$ door hatchback, $\mathrm{CO}_{2}$ emissions from $70 \mathrm{~g} / \mathrm{km}$ and equally priced at 24,100 pounds. There is also the Prius + which has an engine size of 1.8 litre hybrid e CVT. Fuel consumption of up to $74.33 \mathrm{mpg}, 5$ door hatchback, 7 seats, $\mathrm{CO}_{2}$ emissions from $96 \mathrm{~g} / \mathrm{km}$ and priced at 27,550 .

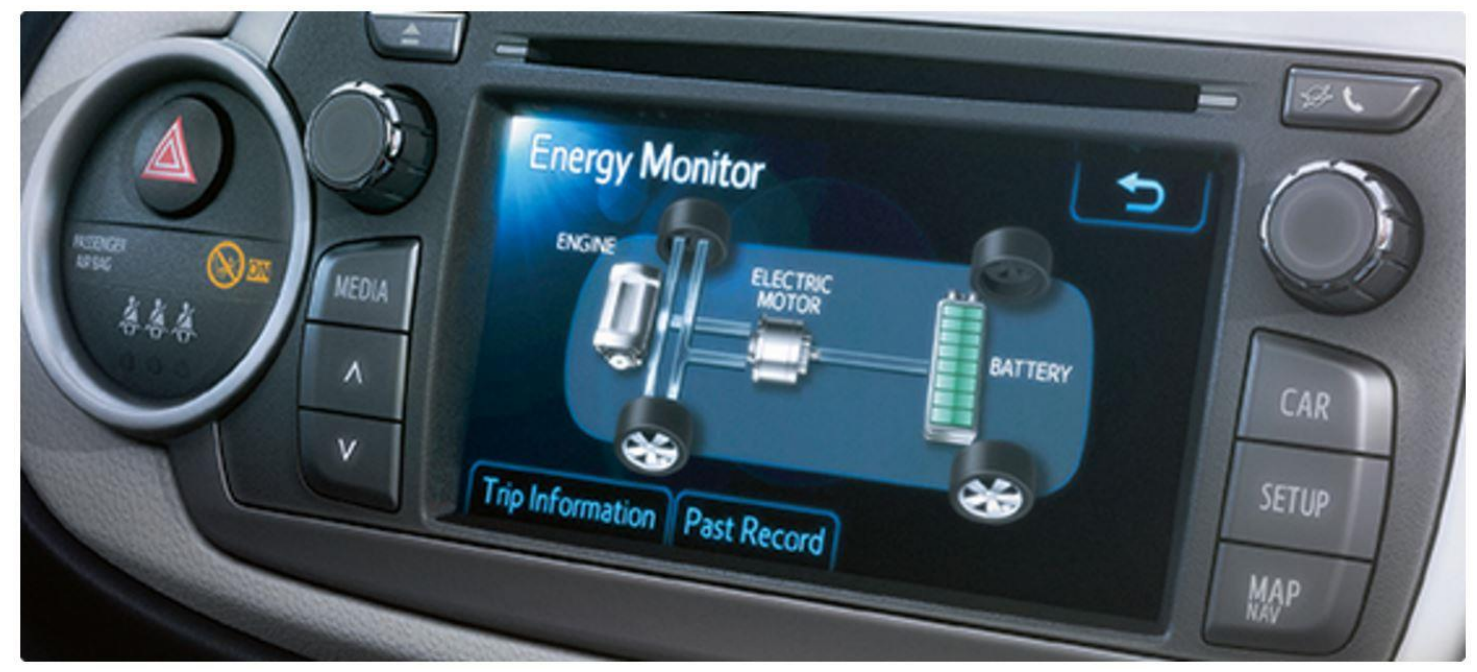

Fig. 14: Interior view of a hybrid Toyota Prius [46].

A little modification has been made by General Motors, where a small petrol engine recharges the battery whilst driving. A hybrid is designed to absorb energy that is often lost through braking and coasting to recharge the batteries. The regenerative braking in turn powers the electric motor without the need for plugging in. hydraulic hybrid vehicles (HHV) technology was developed to use in public buses by a Chinese private firm. The hydraulic device can absorb and deposit energy in the process of braking and releasing the energy when the vehicles restart or speed up. They can save more than 30 percent of fuel consumption and reduce $20-27$ percent of emission. This implies they are able to function as city buses with frequent braking and restarting. 50 HHVs were tested as pilot experiment in Beijing in 2006 and to be introduced in other cities in China if successful [57]. The hybrid electric cars involve two types of sources; internal combustion engine (ICE) and electric motors (EM). This helps the vehicle to be managed in a fuel efficient manner. Hybrid electric vehicles are also divided into three 
categories: mild - HEV, full - HEV, plug - in HEV. The merit of using mild - HEV is related to that of micro - HEV. The power of EM in mild - HEV is larger $(7-12 \mathrm{~kW} / 150 \mathrm{~V})$ than micro HEV. Again electric motors can operate together with ICE to propel the vehicle, leading to greater fuel economy of up to $30 \%$ [58]. The main demerit in using the electric motor is that it cannot function as standalone due to sharing the same shaft with ICE [59]. GM sierra 1500 pickup, Honda civic, Honda Accord and Satum Vue 2009 are some examples of commercial mid HEV's. In order to produce highly efficient cars with better fuel economy, most of the car manufacturers have adopted the approach of producing full - HEV's. This type of HEV is capable of using split power path for both ICE and EM so that they can run the vehicle independently or together. By utilizing this approach, fuel economy can be increased by $40 \%$ without compromising the performance. Full HEV's make use of large energy storage system (ESS) such as battery or ultra-capacitor. The EM of full HEV operates at around 50kW/330V. Full - HEV are also split into four (4) types. These are series full - HEV, parallel full - HEV, series - parallel full HEV and complex full - HEV. Series full - HEV's use EM as the propulsion power provider similar to the battery electric vehicles (BEV's). Series full - HEV's have very high power ICE generator for recharging the battery. The Chevrolet volt is an example of series full - HEV's. It is sometimes considered as extended range full - HEV (EREV) or series plug in HEV. The advantage of this topology is that the ESS size can be reduced depending on the generator power and fuel capacity. The vehicle is capable of using most of the regenerative braking energy to store the ESS but it must be reiterated that this approach reduces vehicle efficiency to around $25.7 \%$ which is the lowest of all types of full HEV's. However this is suitable for urban driving patterns where it only involves stop and run. On the other hand, the parallel full - HEV uses separate propulsion system for ICE and EM linked together by a mechanical coupler. The vehicle topology improves the efficiency of the fuel up to $43.4 \%$. However, the capacity of the battery is weak. Comparatively, parallel full - HEV is preferred compared to series full - HEV because it has higher efficiency and also smaller EM and ESS. The series - parallel full HEV vehicles use one mechanical and one electrical powered coupler for combining the ICE and EM. It uses both series and parallel full HEV's, although the configuration is complex and costly. The complex full HEV topology is similar to the series parallel full HEV, unless it has power converters connected to the motors generators. This design system is good in power handling, more controllable and reliable but very expensive and 
complex. The full - HEV configuration allow manufacturers use existing technology of motor and ESS which leads to cheaper vehicle cost $[48,49,50]$. Some common full hydrides are Toyota Prius, Lexus LS 600h and Nissan Tino inculpates series - parallel full HEV topology whereas Honda civic hybrid, Honda insight and Ford Escape use parallel full HEV approach. The other type of HEV is the plug in HEV. This supports the external charging of the ESS used in the vehicle. Apart from the power of ICE, the ESS is also often charged from the grid power. This design helps the vehicle to use larger ESS thus increases the range of the vehicle. Table 2 shows the summary of the latest improvements in the hybrid industry and Fig. 15 is a schematic of series parallel PHEV. 
Table 2: Summary of the different models of Hybrid Electric Vehicles (HEV's) [51]

\begin{tabular}{|c|c|c|c|c|}
\hline Vehicle model & Type & Energy source & Fuel economy MPGe (city/highway) & Annual fuel cost (per 15,000 miles) \\
\hline Honda Fit 2014 & $\mathrm{BEV}$ & Electric & $132 / 105$ & $\$ 500$ \\
\hline Nissan Leaf 2015 & BEV & Electric & $126 / 101$ & $\$ 550$ \\
\hline Ford Focus Electric 2016 & BEV & Electric & $110 / 99$ & $\$ 600$ \\
\hline Mitsubishi i-MiEV 2016 & BEV & Electric & $126 / 99$ & $\$ 550$ \\
\hline Honda Civic Hybrid 2015 & $\mathrm{HEV}$ & Gasoline & $44 / 47$ & $\$ 800$ \\
\hline BMW Active E 2011 & BEV & Electric & $107 / 96$ & $\$ 600$ \\
\hline BMW Active Hybrid3 2015 & HEV & Gasoline & $25 / 33$ & $\$ 1500$ \\
\hline Toyota Camry Hybrid LE 2015 & $\mathrm{HEV}$ & Gasoline & $43 / 39$ & $\$ 850$ \\
\hline Ford Fusion Hybrid FWD 2016 & $\mathrm{HEV}$ & Gasoline & $44 / 41$ & $\$ 850$ \\
\hline Honda Insight 2014 & HEV & Gasoline & $41 / 44$ & $\$ 850$ \\
\hline Lexus LS 600 h L 2015 & HEV & Gasoline & $19 / 23$ & $\$ 2050$ \\
\hline Toyota Prius 2015 & HEV & Gasoline & $51 / 48$ & $\$ 700$ \\
\hline Porsche Panamera S E-Hybrid 2016 & PHEV & Gasoline - Electric & 51 (combined) & $\$ 1450$ \\
\hline Chevrolet Volt 2015 & PHEV & Gasoline - Electric & $101 / 93$ & $\$ 800$ \\
\hline Toyota Prius 1.82015 & PHEV & Gasoline - Electric & $95 / 50$ & $\$ 650$ \\
\hline Audi A3 E-tron 2016 & PHEV & Gasoline - Electric & 83 (combined) & $\$ 950$ \\
\hline
\end{tabular}




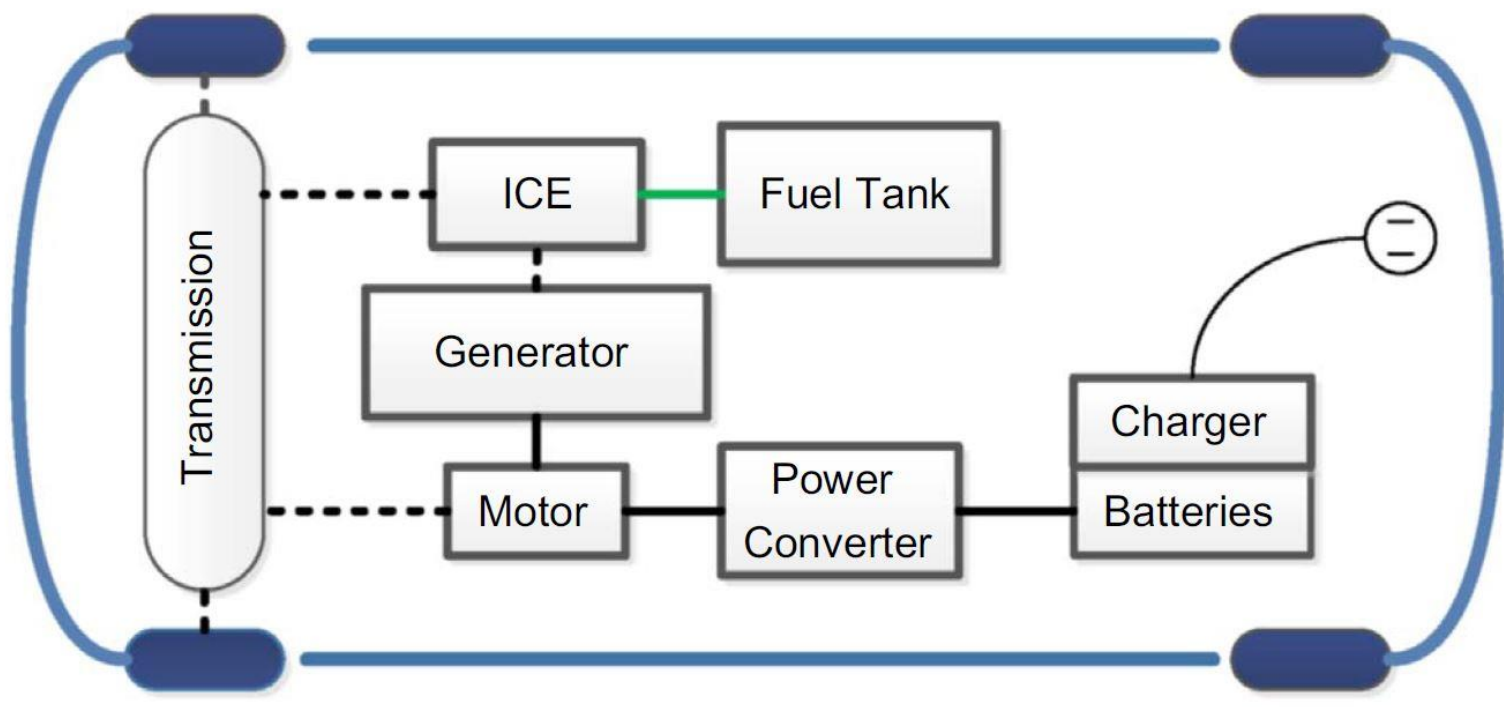

Fig. 15 Schematic drawing of series parallel PHEV [2]

\section{General Operation of Hybrid Cars}

The hybrid cars exposes the possibility of the engine and electric motors work together in different circumstances to give the best possible mileage from hybrid vehicle as shown in Fig 16.

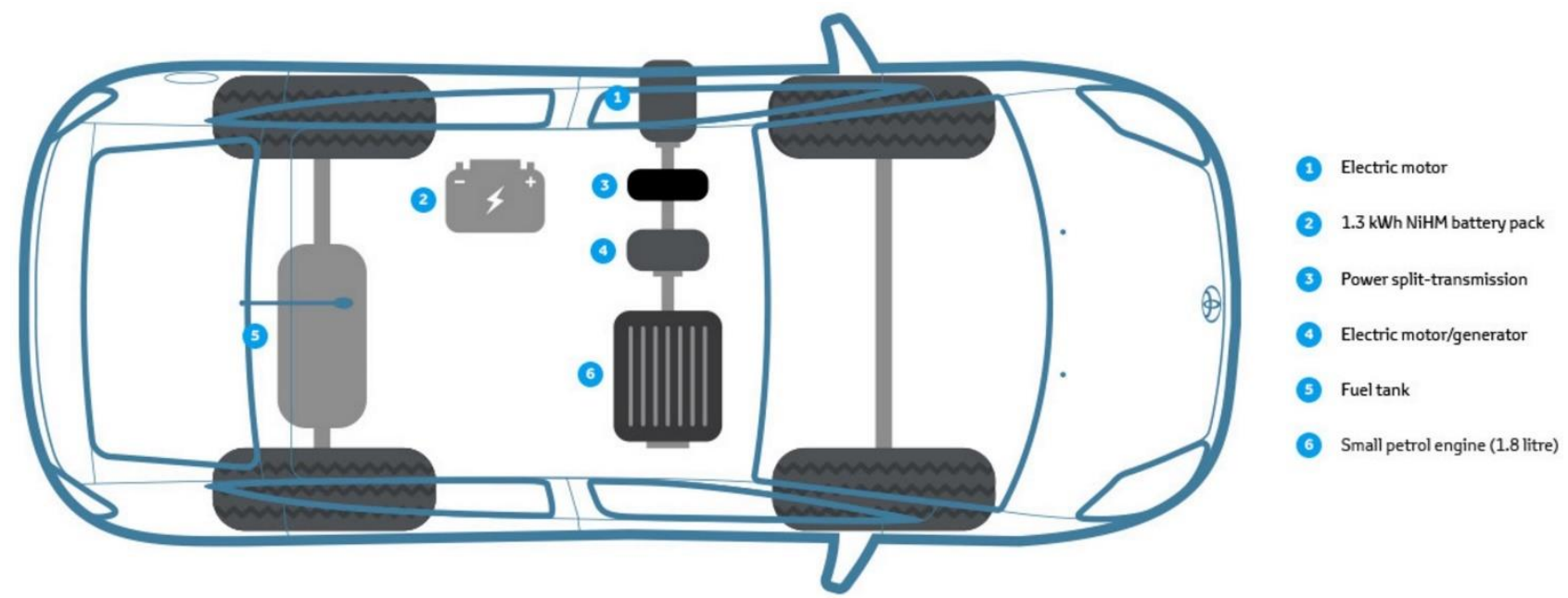

Fig. 16: General Operation of a Hybrid Car [46] 
From Fig. 17, the electric motors power the car, drawing on the battery for the power. Up to $15 \mathrm{mph}$, the vehicle often use only electrical motor for power as shown in Fig.17.

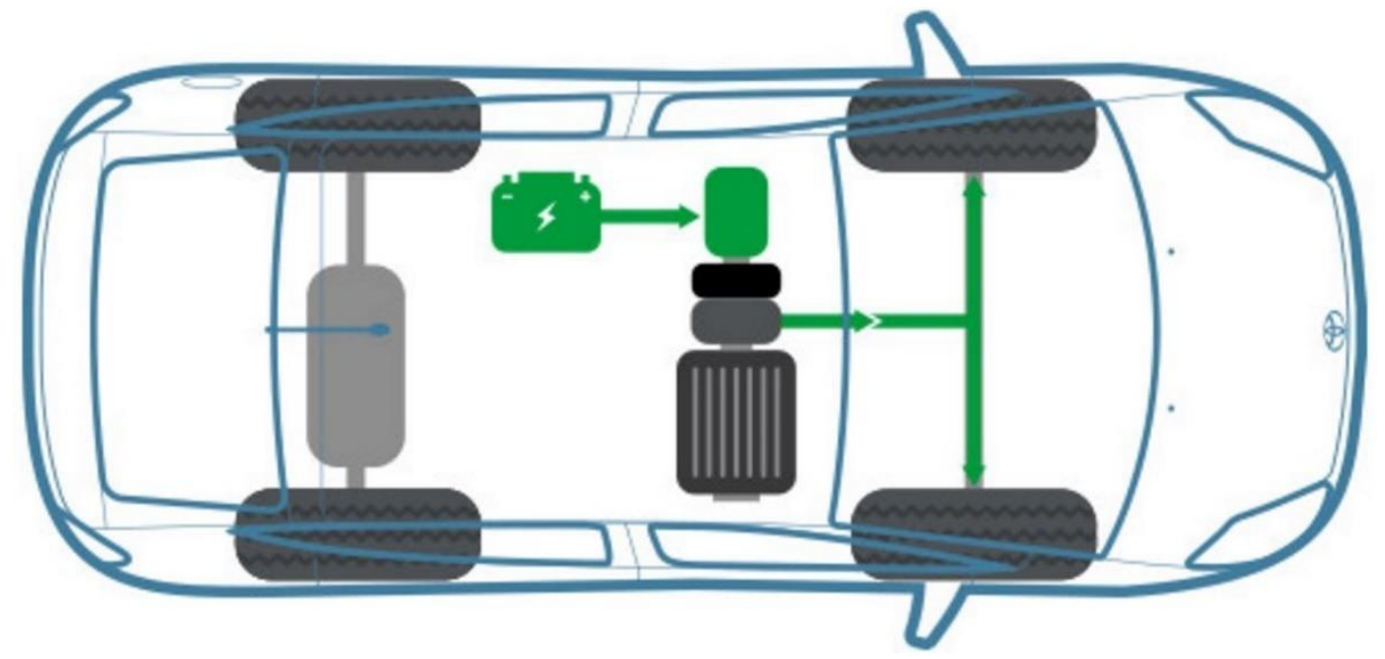

Fig. 17: Operation of a hybrid car when pulling away from a stop [46].

The petrol engine is used when cruising normally as it is most efficient. It is also possible for the engine to power the generator while cruising to produce electricity that can be stored in the battery for later use as shown in Fig 18.

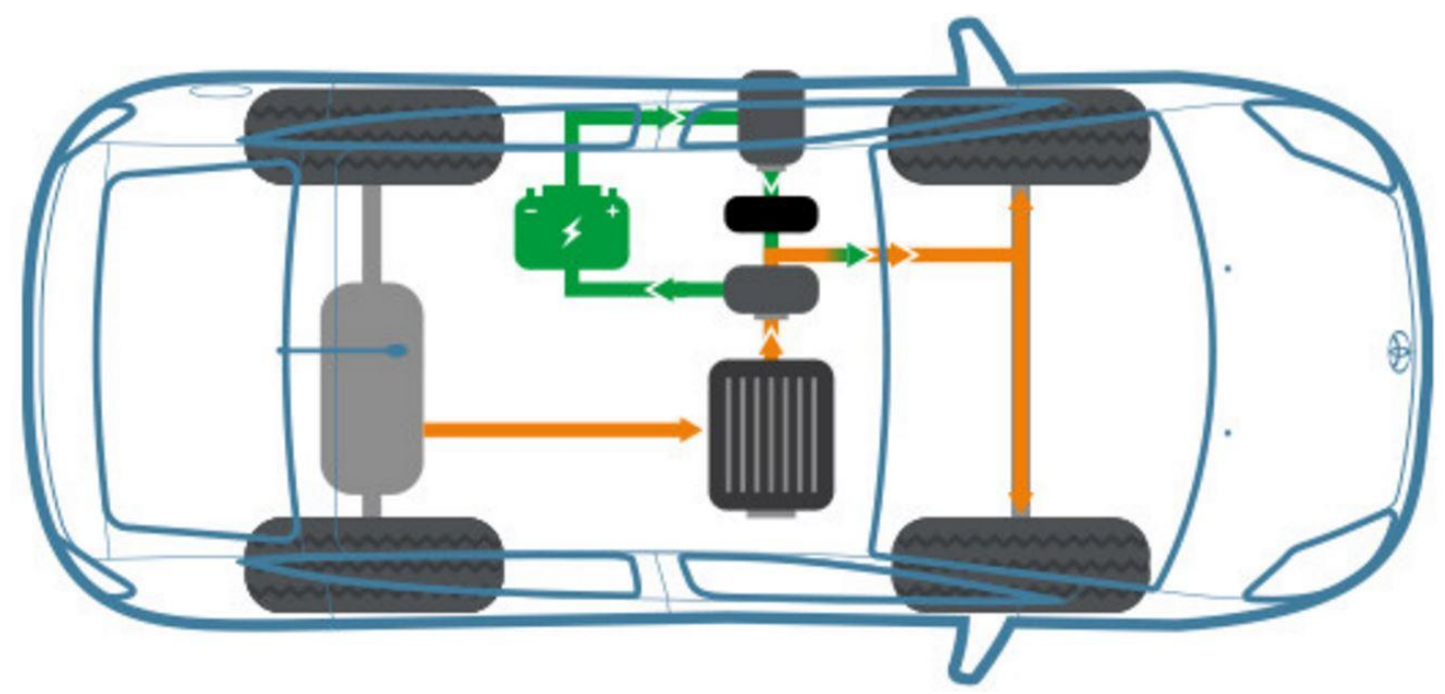

Fig.18: Operation of a hybrid car when in cruising mode [46]

During heavy acceleration, both the engine and electric motors work simultaneously to increase power to the wheels. The petrol engine also powers the generator while the electric motor uses electricity from the battery and generator as needed as shown in Fig. 19. 


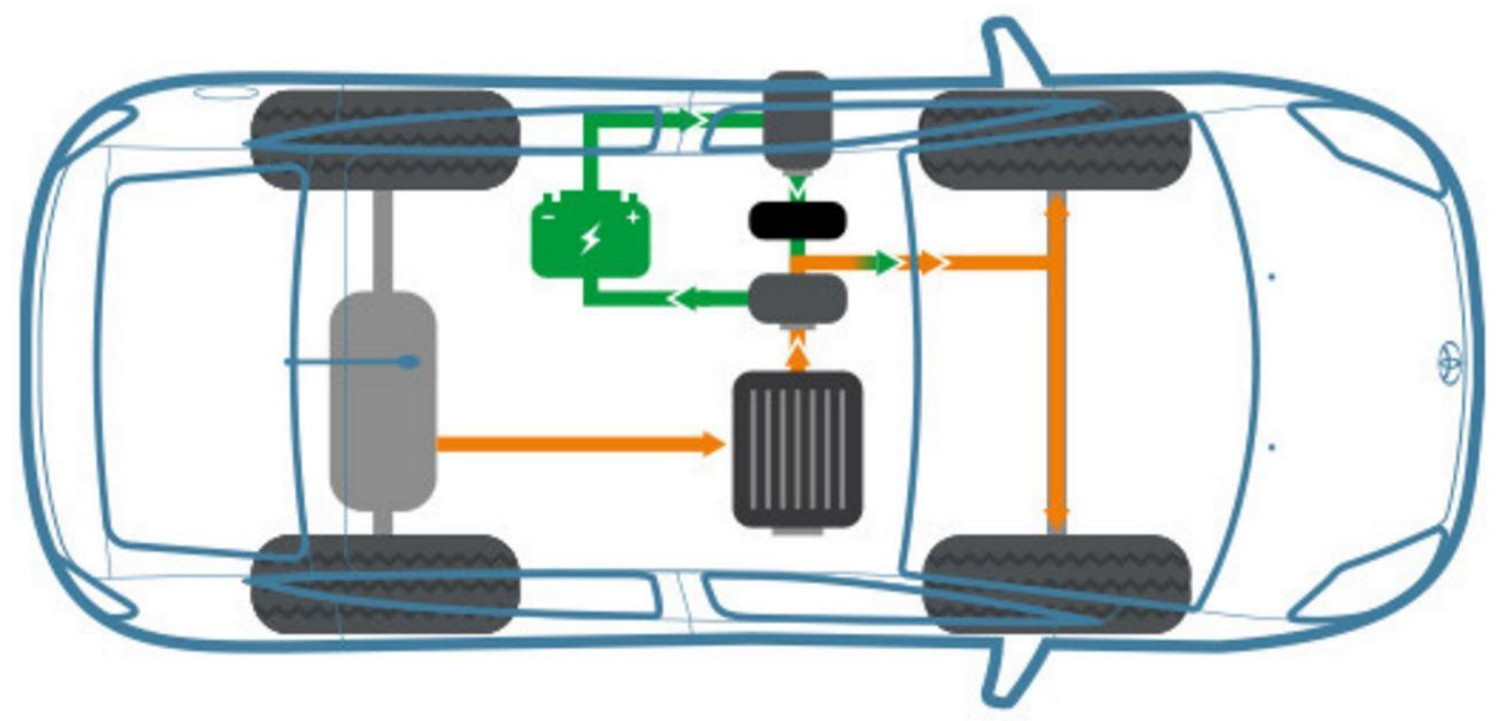

Fig. 19: Operation of a hybrid car during heavy acceleration [46]

When braking as shown in Fig. 20 or one takes the foot of the gas hybrid cars, especially those designed by Toyota, use a clever system called regenerative braking. As the car no longer needs to apply power to the wheels, it allows the spinning wheels to power the vehicles generator which produces electricity and stores it in the battery for later use.

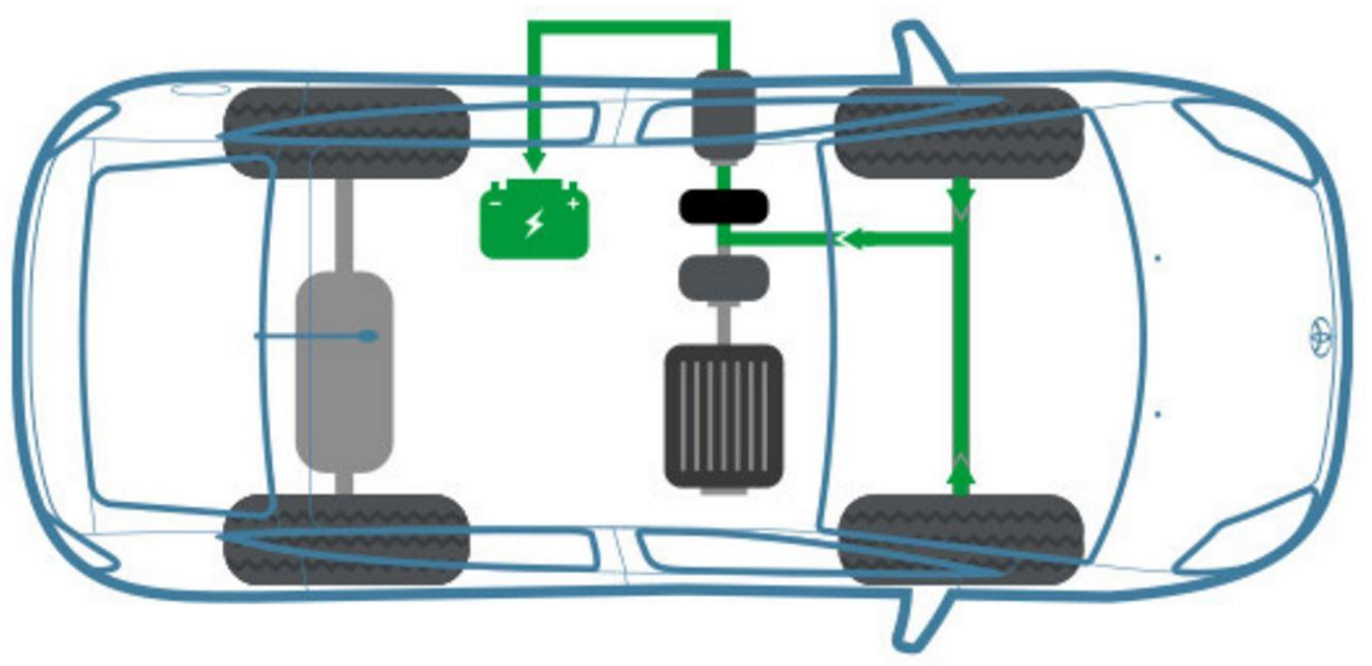

Fig. 20: Operation of a hybrid car during braking and cruising [46]

Both the conventional engine and electric motor turn off and the car switches to battery power to run everything it needs such as its radio, air conditioning, lights, etc. when it finally comes to a stop as shown in Fig. 21. 


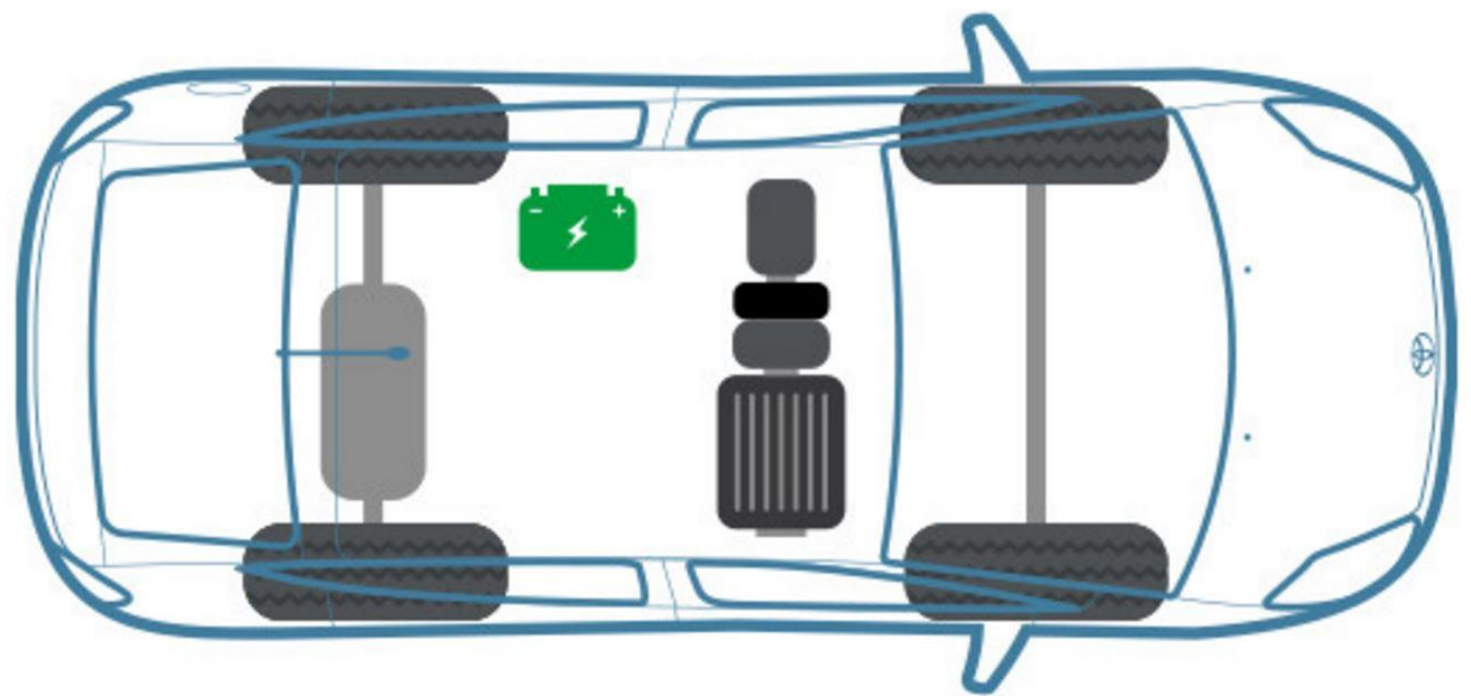

Fig. 21: Operation of a hybrid car when it comes to complete stop [46]. 


\section{Plug - in Hybrid Cars}

The plug - in electric vehicle as shown in Fig. 22 is a hybrid vehicle with batteries capable of being recharged by connecting a plug to an electric power source. Just like a hybrid car, it is also powered by an on-board engine and a battery/electric motor. It also comes with a plug for connecting to the electric grid. Morgan Stanley in 2008 made a tremendous research on Plug - in Hybrid Cars (PHEV).

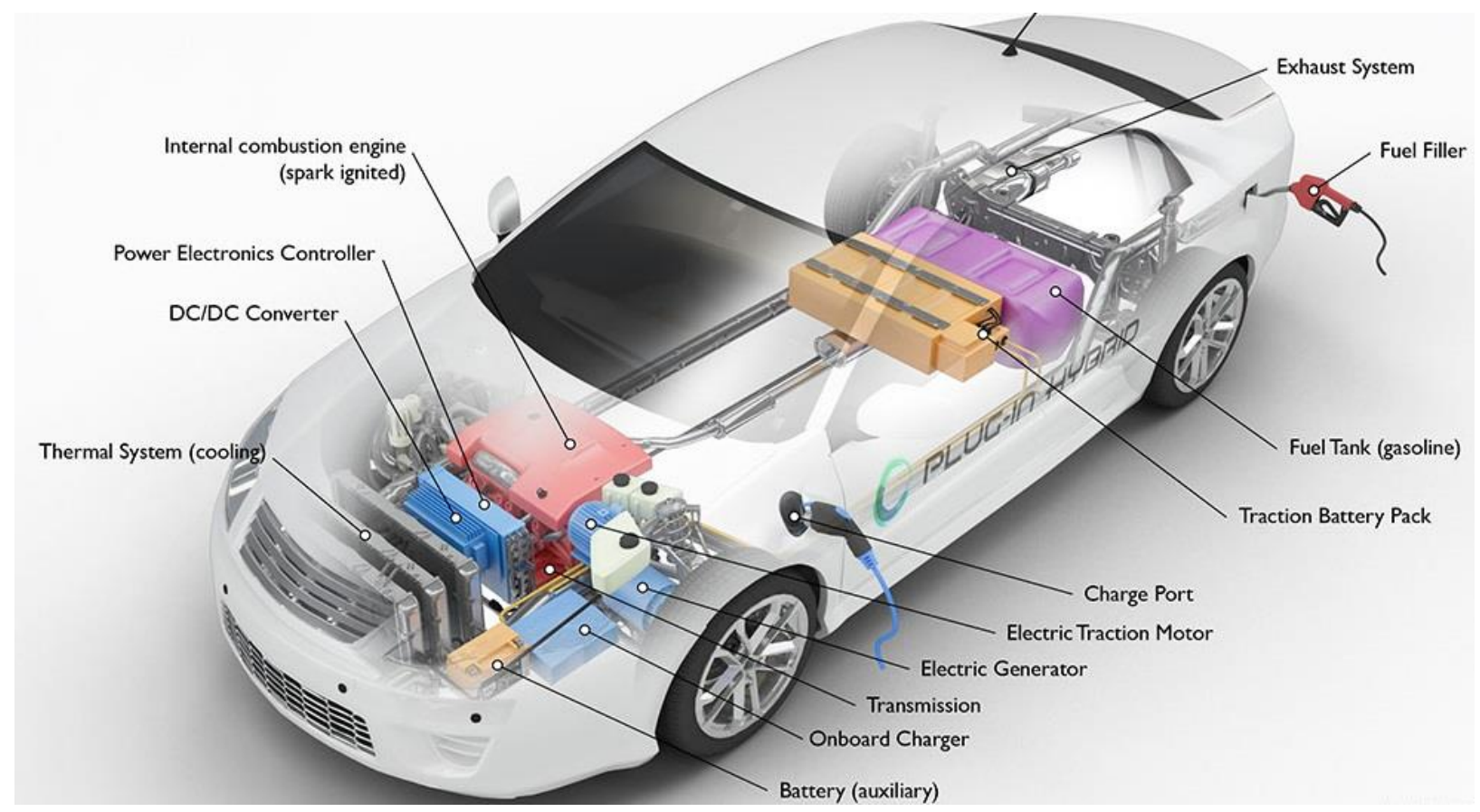

Fig. 22: Plug - in Hybrid Car [61].

They suggested that plug - in electric cars are capable to transform the automobile industry over the next couple of decades. Their argument about the progress of plug in electric cars was built on the basis that they could provide a cost - effective, practical solution to improve the automotive fuel economy and reduce emissions as well. The plug - in system gives PHEV an extended 20-40 miles all electric driving range vs. current hybrid vehicles and also the ability to drive long distances like a regular car. PHEVs combine the best electric and hybrid drive technologies. Their function could either be in electric or hybrid mode. The cost for electricity to power PHEV for all - electric operation is estimated at less than one quarter of the cost of gasoline [60]. General Motors in 2011 produced a plug in hybrid car which was the Chevrolet Volt. Having fully charged batteries, the Chevrolet Volt can travel up to 40 miles. A small 4 
cylinder ICE is used to provide a longer range. The Volt had a potential range of up to 640 miles on a single tank of fuel without external charging station needed. The battery can be fully charged by plugging the car into a residential electric socket [61]. In 2011 Volvo was also actively working with the Swedish energy company Vattenfall to build plug in hybrid vehicles with charging systems. The agreement was for Volvo to manufacture the cars and for Vattenfall to build the charging systems. The diesel hybrid car was to combine with a rear - wheel drive electric motor which is powered by a lithium ion battery pack and a front - wheel drive diesel engine. During that period, Magna International also worked extensively with Ford to develop a new Ford battery electric vehicle. Fisker Automotive Inc. also built PHEV in 2008 after going into agreement with Valmet Automotive to build Karma in Finland.

Today Ford has a number of electric vehicles but in 2017 the Fusion Energy Titanium and the Cmax Hybrid SE are the two latest model of PHEV designed by the company on the market. The fusion hybrid or Fusion Energy Plug-in Hybrid comes with a dual LCD, smart gauge with Eco Guide which provides real - time information to aid efficiency of the car as shown in Fig. 23.

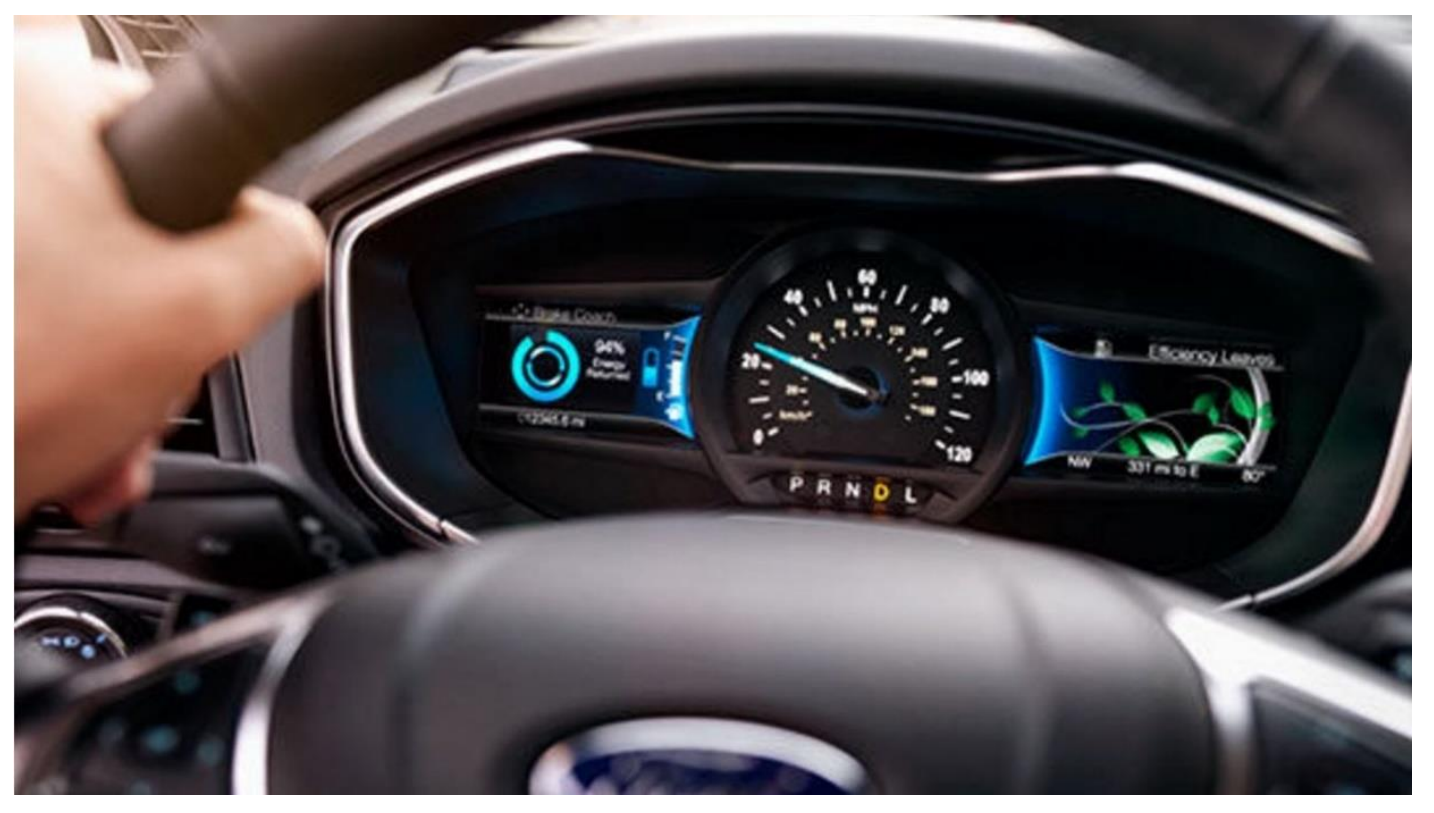

Fig. 23: Dash board of a Ford Fusion Energy PHEV [61]

It also comes with a configuration screens such as Brake coach which helps to maximize the vehicle efficiency. Left - side display screens include Engage and Empower modes. When in Engage, the separate gauges to engine power and lithium - ion battery power and EV is 
displayed when the vehicle is operating on battery only. The lithium battery shown in Fig. 24 comes with the Fusio Energi Plug which is $7.6 \mathrm{kWh}$ lithium ion battery. The fusion hybrid uses a $1.4 \mathrm{kWh}$ lithium ion battery.

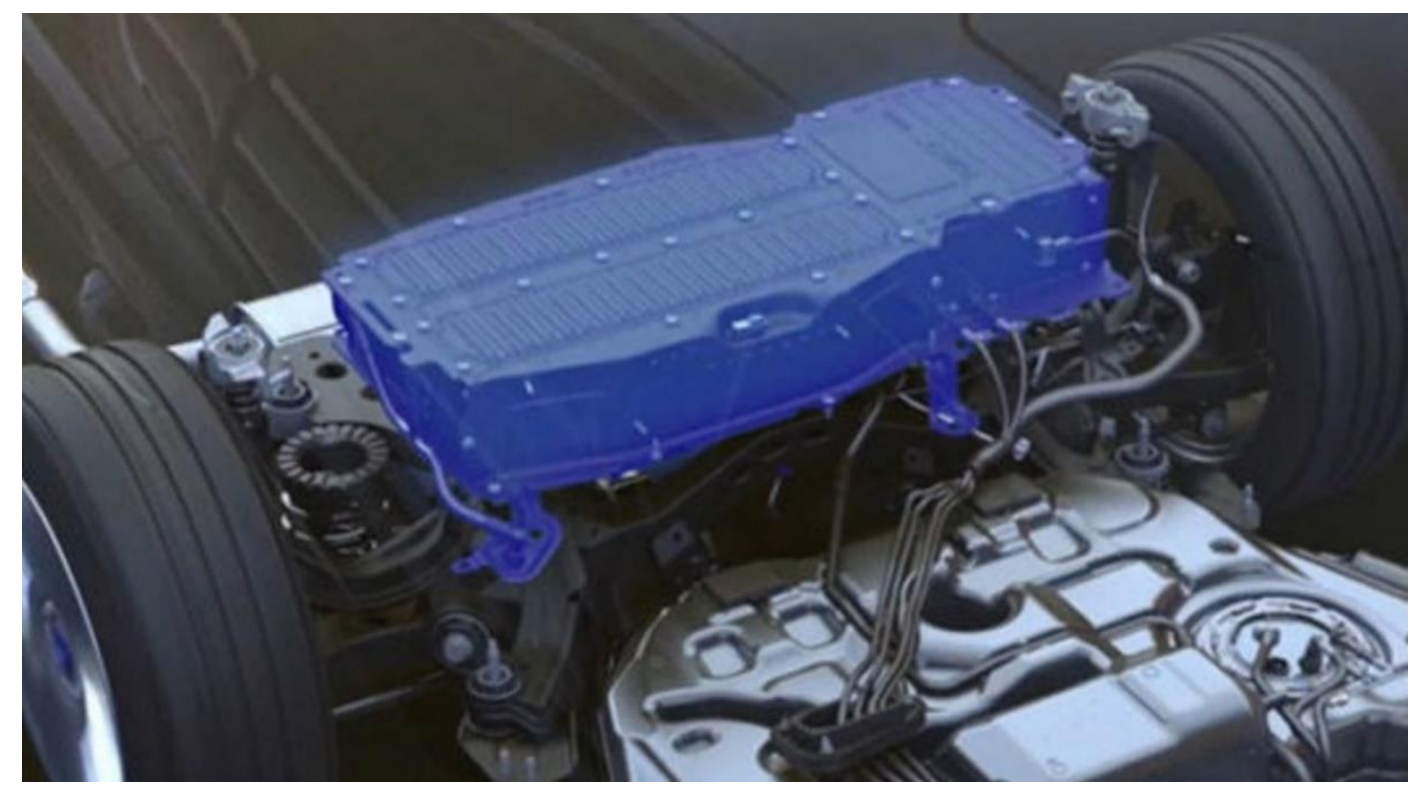

Fig. 24: Lithium battery for Fusion Energi PHEV [61]

It also comes with a hybrid 2.0L I-4 Atkinson cycle powertrain, coupled with an electronically controlled continuously variable transmission (eCVT) and a high - voltage electric motor.

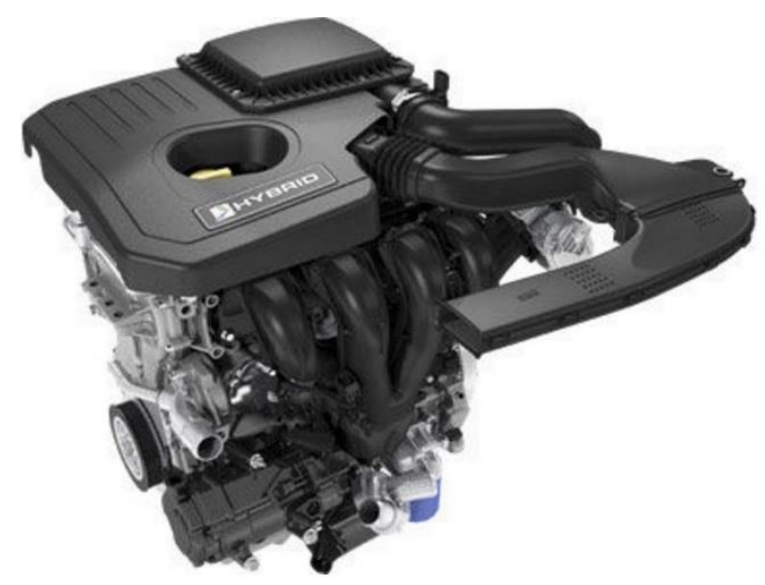

Fig. 25: 2.0 L IVCT Atkinston - cycle I - 4 Engine and Electric motor [61]

This clearly attests to the fact that the plug in hybrid electric vehicle (PHEV) technology has progressed considerably in the last decades and still continues to make massive strides in the automotive industry. 


\section{Plug - in Charge Station}

It is possible to charge a PHEV using an electrical socket at home or in any commercial area. The main infrastructure that is needed is a charging station where the PHEV will gain its power from either at home or any commercial location. The cost of establishing a charging area according to Madslien [54] was 2000 pounds. It is also being argued that the future of electric vehicles would be brighter if the electricity power can be supplied from nuclear power station or alternative renewable energy sources such as solar or wind. Electricity generated at night or offpeak time can be stored and used for electric car overnight charging. The promotion of PHEV will improve efficiency of electricity power supply. The power would primarily come from power plants such as wind or wave generation facilities that are kept operating even though the electricity is not used for more traditional needs. Thus the utilities cost to generate the power to charge electric vehicles at night or off-peak is low. Most electric cars produced lately are quite expensive than petrol cars though car makers are working around the clock to beat down the cost of these cars. Some challenges that this technology is often confronted with has to do with resale value, maintenance costs and available charging stations. A number of companies are doing everything to get the attention of customers in the automobile industry towards this fine technology. Leasing agreements such as mobile contract business model will give one solution to promote EVs. The business model for a better place is based on switchable batteries financed with a pay per mile service contract. This pay per mile contract will cover the initial purchase price, maintenance and charging infrastructure network. It is anticipated that Israel will stop depending on oil by 2020. This forecast was made in 2009; hence they started the installation of plug in charge stations at the headquarters of Teva Pharmaceuticals in Israel. Several companies supported this good initiative intended to boost the sale of electric cars on the automobile market [62].

\section{Fuel Cell Electric Vehicles (FCEV's)}

Fuel cell electric vehicles (FCEV's) also fall under the all-electric vehicle types hence has also similar powertrain like BEV but its energy source is a fuel cell stack. An FCEV is driven using hydrogen producing only water and heat hence there is no exhaust pollutant, thus it's recognized as zero emission vehicle. PEMFC is the mostly preferred fuel cell for vehicular purposes because it has high power density and lower operating temperature $\left(60^{\circ} \mathrm{C}-80^{\circ} \mathrm{C}\right)$ and also very low 
corrosion compared to the other type of fuel cell $[63,64]$. Direct hydrogen is used as the fuel which is stored in a tank mounted in the vehicle or the hydrogen obtained from fuel using a fuel processor. For a constant power supply, fuel cell is one of the best options but not appropriate for a sudden change in power demand. Fig. 26 shows a typical powertrain configuration for FCEV's having an optional processor.

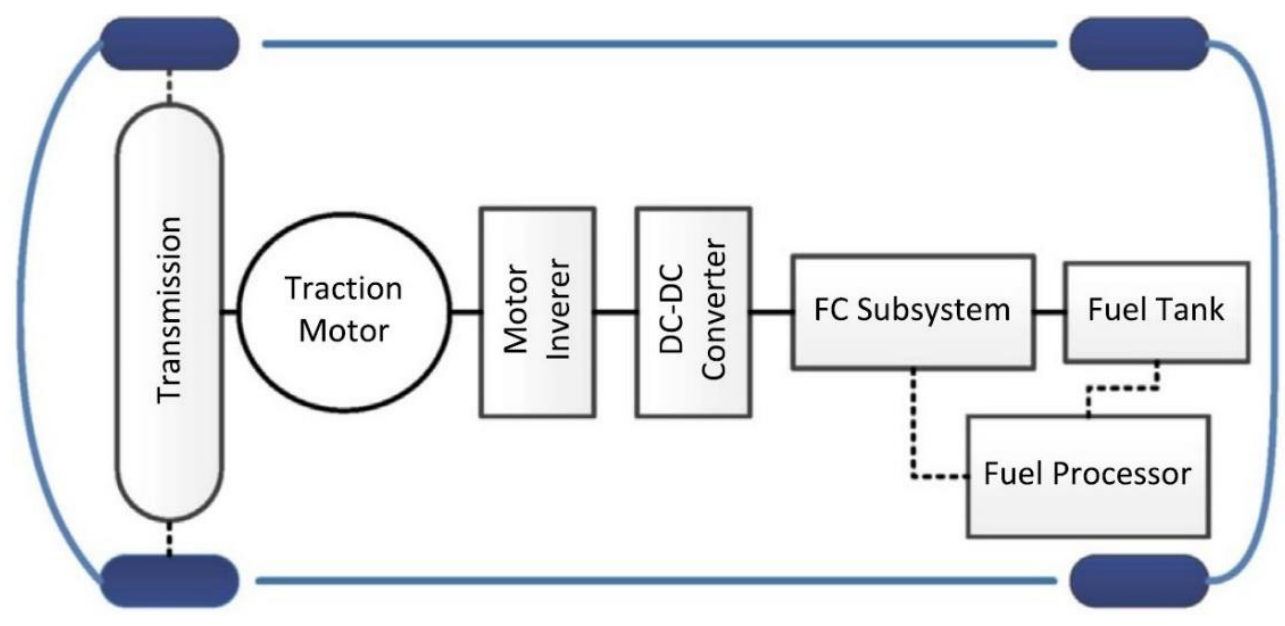

Fig. 26: Schematic diagram of the powertrain of FCEV [2]

Slow speed vehicles like trams, submarines, buses, forklifts and some material handling vehicles are suitable for FC application. Due to recent high technological advancement, fuel cells are now being used for high speed vehicles. Modification of the powertrain is first done in order for fuel cells used in high speed vehicles. Automobile manufacturers like Hyundai, Toyota and Honda are producing high performance fuel cells for their vehicles. Different energy management techniques are being adopted focusing on other aspects like fuel economy, energy losses and vehicle efficiency. The first fuel cell electric car, the Electrovan was manufactured by General Electric (GM) in 1966. The vehicle power source was made of an alkaline fuel cell (AFC) and two cryogenic tank vessels for liquid hydrogen and liquid oxygen [64]. The fuel cell stack served as the main component of the complete fuel cell power system. There is a wide range of fuel cells available including mild and high temperature fuel cells. However, the low temperature fuel cells working with a proton conducting polymer membrane (proton exchange membrane, PEM) are suitable for automotive applications. They combine a comparatively low operating temperature typically $60^{\circ} \mathrm{C}$ to $80^{\circ} \mathrm{C}$ with high power density, the option of conventional air 
operation and the potential of being manufactured at low cost. PEM fuel cell (Fig. 27) based power systems provide similar performance features as ICEs with which they are competing.

The stack for the fuel cell is built from hundreds of single cells and just like a battery transforms chemical energy into electrical energy; it also directly transforms the chemical energy into electrical energy. A separate system is built to function as a channel to transport the fuel to the electrode. If fuel and oxidant are supplied to the fuel cell at enough quantities, the generation of electrical energy is ensured. Removing the reaction waste as well as supplying all the single cells of the stack with fuel remains the main challenge of fuel cells. The product waste for PEM fuel cells is water hence not much of a hustle is often needed to get this waste out of the fuel cell.

After the technology transition from AFCs to PEM fuel cells, there have been several progresses made in the Electric Vehicle industry. Some of these generational transitions are from HydroGen1 to Hydrogen4. The integration of fuel cell system into vehicles can be done similarly like the integration of ICEs. It has been demonstrated that enough powerful and compact drivetrains could be realized. 
(A)

(1) Bipolar plate (cathode side)

(2) Diffusion medium (cathode side)

(3) Membrane electrode assembly

(4) Diffusion medium (anode side)

(5) Bipolar plate (anode side)

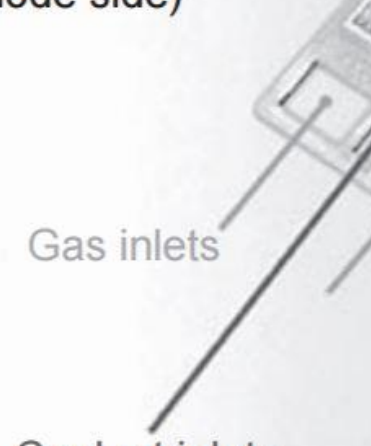

\section{Coolant inlets}

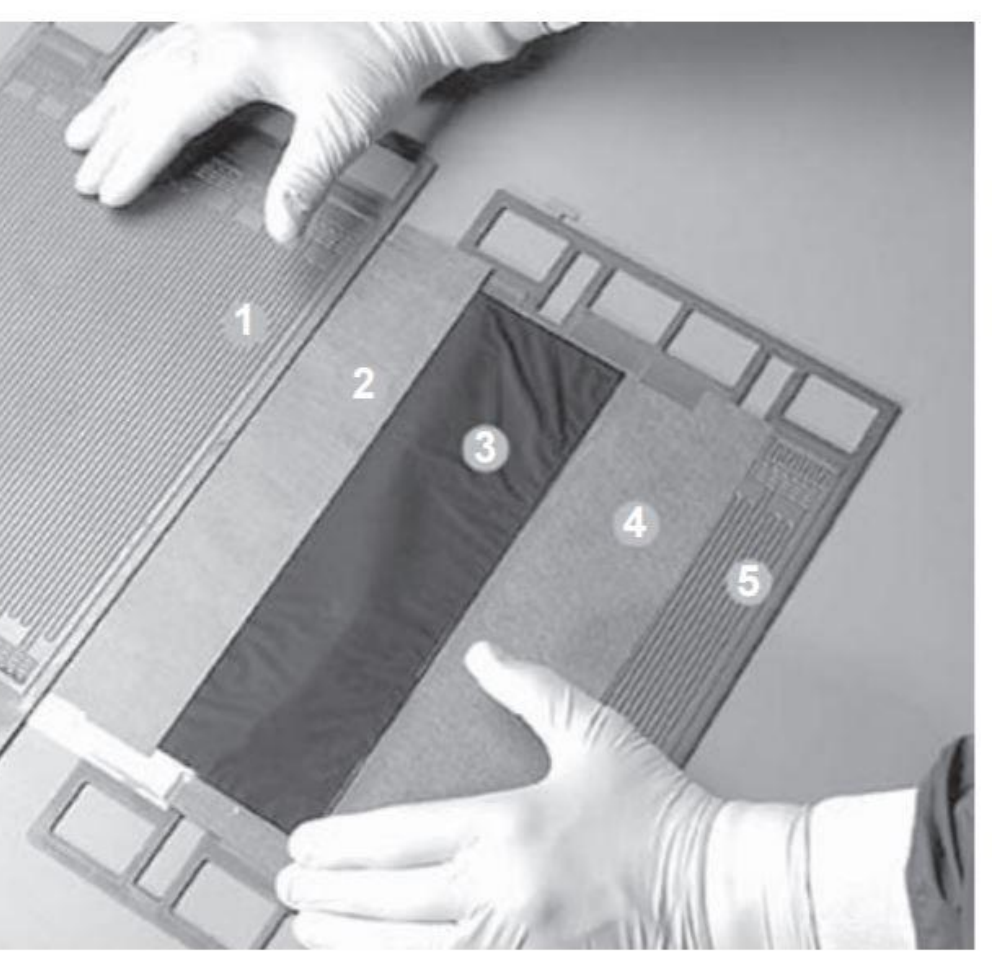

(B)

(a) Acidic electrolyte, e.g. in case of a PEMFC:

(b) Alkaline electrolyte, e.g.,

$$
\begin{aligned}
& \begin{array}{ll}
\mathrm{H}_{2} & \rightarrow 2 \mathrm{H}^{+}+2 \mathrm{e}^{-} \\
2 \mathrm{H}^{+}+2 \mathrm{e}^{-}+1 / 2 \mathrm{O}_{2} & \rightarrow \mathrm{H}_{2} \mathrm{O} \\
\mathrm{H}_{2}+1 / 2 \mathrm{O}_{2} & \rightarrow \mathrm{H}_{2} \mathrm{O}
\end{array} \\
& \text { anode reaction } \begin{array}{ll}
\mathrm{H}_{2}+2 \mathrm{OH}^{-} & \rightarrow 2 \mathrm{H}_{2} \mathrm{O}+2 \mathrm{e}^{-} \\
\text {cathode reaction } & \frac{1 / 2 \mathrm{O}_{2}+2 \mathrm{e}^{-}+\mathrm{H}_{2} \mathrm{O}}{\mathrm{H}_{2}+1 / 2 \mathrm{O}_{2}} \quad \rightarrow \mathrm{H}_{2} \mathrm{O}
\end{array}
\end{aligned}
$$

Fig. 27: (A) Setup of PEM fuel cell; (B) Chemical reactions at the electrodes [43]. 
The fuel cell system and the electric traction system of the GM HydroGen3 were packed in a way that they fitted into the same volume as an ICE propulsion module even the same mounts could be used. Such an integrated fuel cell module (population dress - up module, PDU) helps in the simple and cost effective vehicle assembly in existing facilities. The PDU are a probable technology scenario for the introduction of volume production on the basis of existing platforms. There is however no technical restrictions that would rule out completely different configuration of the fuel cell powertrain components on board the vehicle. The scalability of fuel cell systems also facilitates the adaptation of different vehicle sizes. One example is the fuel cell system that was initially developed for the GM hydroGen3 van and later was adapted to a small vehicle, the Suzuki MR Wagon FCV, using a shorter fuel cell stack with a reduced cell count. It was also finally adapted to a GMT800 truck by doubling the stack and some other components [45]. The birth of the GM HydroGen3 after a public presentation exposed a 70MPa $\mathrm{CGH}_{2}(\mathrm{Compressed}$ gaseous hydrogen) storage system which was the state of the art then. It was seen even in Fig. 6that this single vessel tank system could be used for the storage of $1600 \mathrm{Wh} / \mathrm{kg}$ of hydrogen. Typically about $4-7 \mathrm{~kg}$ of hydrogen has to be stored on board. This was a major challenge for the vehicle integration. Furthermore cylinder vessels were required for $\mathrm{CGH}_{2}$ fuel storage. In existing vehicles, without modifications, there is not enough space for hydrogen storage devices that could provide a range comparable to conventional vehicles.

Hence rear body modifications are necessary to integrate the hydrogen storage vessels. Fig. 28 shows the design of the Chevrolet Sequel by GM providing enough space for three large 70MPa $\mathrm{CGH}_{2}$ vessels (Total fuel capacity: $8 \mathrm{~kg}$ of hydrogen). Through this approach, the FCEV operating range could increase tremendously by more than 300 miles as demonstrated on public roads between suburban Rochester and New York City in May 2007. The fuel cell system of the Sequel has been packaged into the vehicle underbody as well, offering flexibility for the interior design. 
(A)
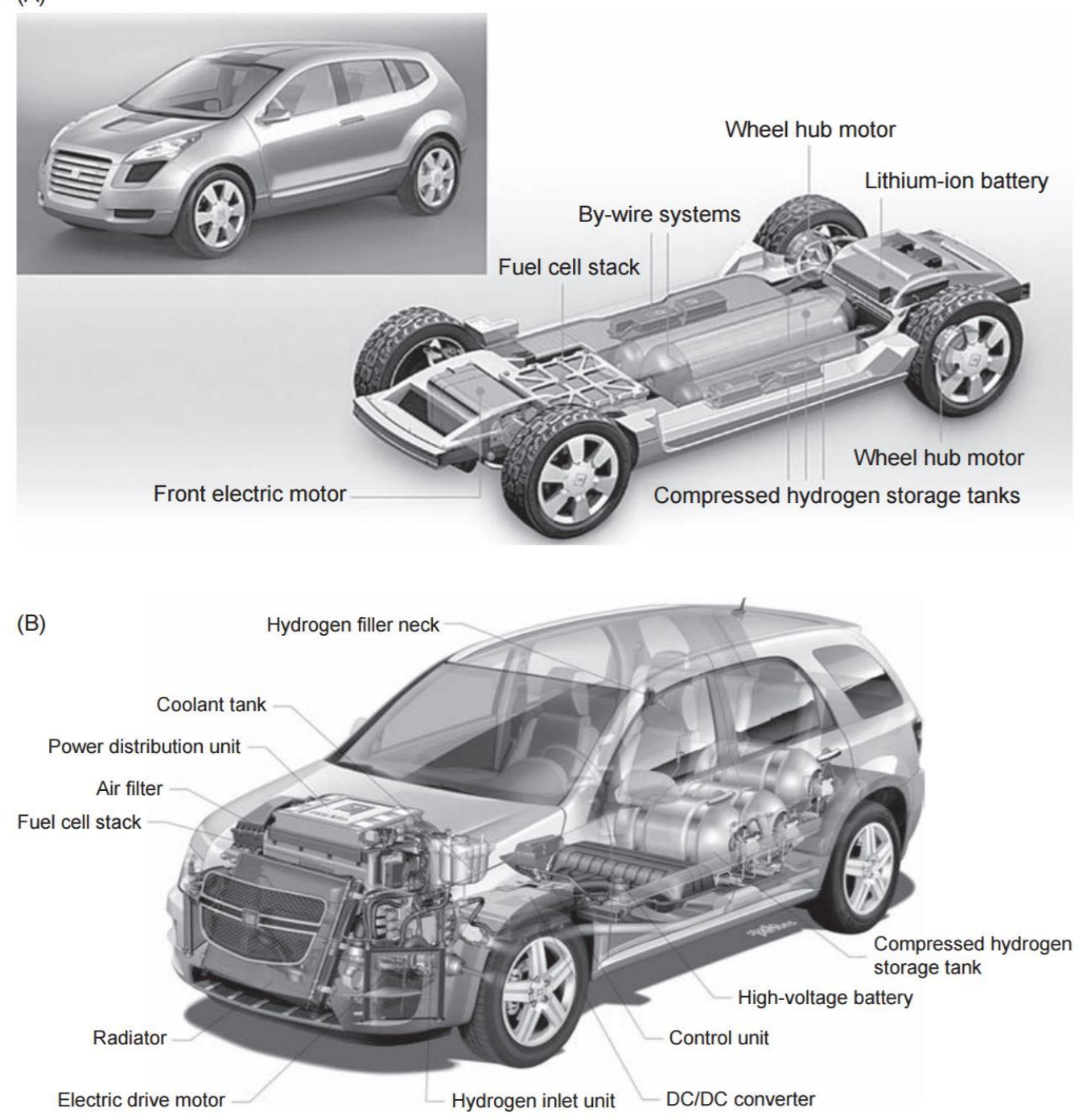

Fig. 28: (A) GM Sequel and the skateboard Chassis (b) GM HydroGen4 vehicle [43].

Although the Sequel is only a concept vehicle with no production intent then, it was anticipated the vehicle could be developed and optimized for the specific characteristics and opportunities that fuel cells and $\mathrm{H}_{2}$ can offer. Since autumn 2007, within the framework of Project Driveway, more than 100 cars of the generation HydroGen4 shown in Fig. 28(B) were developed and demonstrated in countries like Germany and the United states. From table 3 which happens to be the technical sheet for the GM HydroGen4, it is seen that this vehicle could offer a higher performance than other EVs. The car could be operated and started very low temperature down to $-25^{\circ} \mathrm{C}$. 
Table 3: Technical Specifications of the GM HydroGen4

\begin{tabular}{|l|l|}
\hline Vehicle type & $\begin{array}{l}\text { Five }- \text { door, crossover vehicle, front }- \text { wheel drive, based } \\
\text { on Chevrolet Equinox }\end{array}$ \\
\hline $\begin{array}{c}\text { Dimensions: } \\
\text { Length }\end{array}$ & $4,796 \mathrm{~mm}$ \\
Width & $1,814 \mathrm{~mm}$ \\
Height & $1,760 \mathrm{~mm}$ \\
\hline Wheelbase & $2,858 \mathrm{~mm}$ \\
\hline Trunk space & $906 \mathrm{Litre}$ \\
\hline Weight & $2,010 \mathrm{~kg}$ \\
\hline Payload & $340 \mathrm{~kg}$ \\
\hline Hydrogen Storage System: & 3 Type IV CGH 2 Vessels \\
Type & $70 \mathrm{MPa}$ \\
Operating Pressure & \\
\hline Fuel cell system: & $\mathrm{PEM}$ \\
Type & 440 \\
Cells & $93 \mathrm{~kW}$ \\
Power & $\mathrm{Ni}-\mathrm{MH}$ \\
\hline Battery system: & $35 \mathrm{~kW}$ \\
Type & $1.8 \mathrm{kWh}$ \\
Power & \\
Energy content & Three - phase, synchronous motor \\
\hline Electric propulsion system: & $73 \mathrm{~kW}$ \\
Type & $94 \mathrm{~kW}$ \\
Continuous power & $320 \mathrm{Nm}$ \\
Maximum Power & $160 \mathrm{~km} / \mathrm{h}$ \\
Maximum torque & $12 \mathrm{~s}$ \\
\hline Performance: & $320 \mathrm{~km}$ \\
Top speed & $-25^{\circ} \mathrm{C} \mathrm{to}+45^{\circ} \mathrm{C}$, Vehicle can be parked at ambient \\
Acceleration $(0-100 \mathrm{~km} / \mathrm{h})$ & temperature $<0^{\circ} \mathrm{C}$ (without external heating) \\
Range & \\
\hline Operating Temperature & \\
\hline
\end{tabular}


From the technical data sheets in table 3, the electrical propulsion provides a maximum torque of $320 \mathrm{Nm}$ at the motor and accelerates the Hydrogen 4 in less than $12 \mathrm{~s}$ from 0 to $100 \mathrm{~km} / \mathrm{h}$. the continuous power output of the electric motor of $73 \mathrm{~kW}$ is sufficient for a maximum speed of $160 \mathrm{~km} / \mathrm{h}$; the maximum performance from the table is $93 \mathrm{~kW}$. Three carbon-fibre tanks on-board store $4.2 \mathrm{~kg}$ of hydrogen and enable a range of $320 \mathrm{~km}$. The empty hydrogen storage system can be completely refilled within 3 minutes according to SAE (Society of Automotive Engineers) j2601 and SAE J2799. A nickel metal - hydride battery ( $\mathrm{Ni}-\mathrm{MH})$ with an energy content of $1.8 \mathrm{kWh}$ is also installed on-board to improve the agility of the vehicle and also to increase the efficiency [66].

\section{Fuel cell Hybrid electric vehicles (FCHEV)}

The automobile industry has made modification of FCEV powertrain leading to a new vehicle configuration called FCHEV. This vehicular system depends on another energy storage system (ESS) for supporting the fuel cell. Depending on the power demand and supply a battery or ultracapacitor can be used as the ESS which can be charged or discharged. To ensure smooth and efficient running of the vehicle, several factors must be considered in order to use fuel cell as the main energy source and battery or ultra-capacitor as ESS in a hybrid vehicle. An example of an FCHEV power train is shown in Fig. 29 [67]

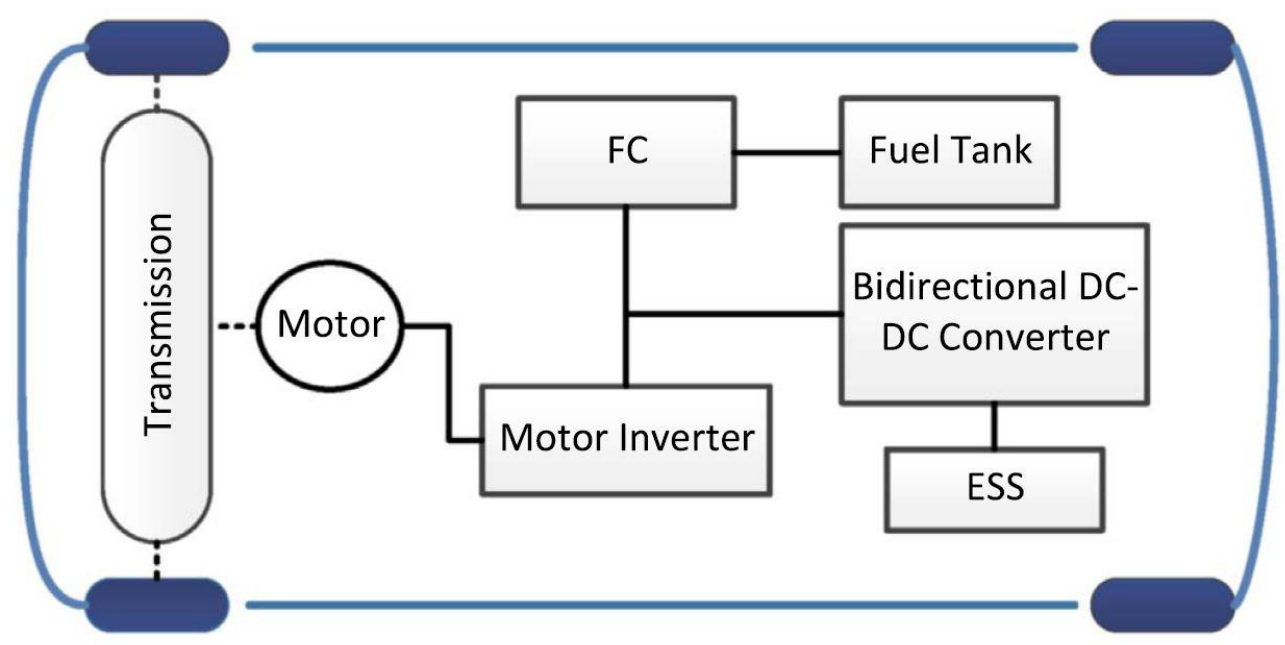

Fig. 29 Schematic diagram of powertrain of Fuel cell hybrid electric vehicle (FCHEV) [2] 
The main challenge here is the power converter size, weight and reliability. Again, the converter efficiency, electromagnetic interference (EMI) and output voltage and current ripples are some necessary factors considered. The recent positive strides in the FCHEV research have contributed to the successful patronage of fuel cell vehicles. Table 4 shows prototypes and commercialization of FCHEV vehicles in single fuelling and fuel economy in both city and high way driving conditions [67]. 
Table 4: Various types of electric cars [2]

\begin{tabular}{llll}
\hline Vehicle model & Type & Energy source & Fuel economy MPGe (city/highway) \\
\hline Honda FCX clarity 2014 & FCEV & Hydrogen & $58 / 60$ \\
Honda Clarity Fuel Cell 2017 & FCHEV & Hydrogen & -- \\
Toyota Mirai 2016 & FCEV & Hydrogen & $66 / 66$ \\
Hyundai Tucson Fuel Cell 2016 & FCEV & Hydrogen & $49 / 51$ \\
Hyundai ix35 2013 & FCHEV & Hydrogen & -- \\
Toyota FCHV-adv & FCHEV & Hydrogen & $39 / 43$ \\
Audi Sportback A7h-tron Quattro 2014 & FCHEV & Hydrogen & 62 (overall) \\
Honda FCV Concept 2014 & FCEV & Hydrogen & -- \\
Mercedes-Benz F800 2010 & FCEV & Hydrogen & -- \\
Nissan Terra FCEV SUV 2012 & FCEV & Hydrogen & - \\
Roewe 950 Fuel Cell 2014 & FCEV & Hydrogen & - \\
Volkswagen Golf Hymotion 2014 & FCEV & Hydrogen & -- \\
Kia Borrego FCEV & FCEV & Hydrogen & - \\
\hline
\end{tabular}

46 | P a g e 


\section{Sources of Energy for fuel cell hybrid electric vehicle (FCHEV)}

Flywheel, fuel cell, battery and ultra-capacitors (UC) are some well-known energy sources for FCHEV's. The basic power flow configuration determines the type of energy source for the FCHEV. This source also has very high supply of energy and is often referred to as main energy source (MES) and another one with high power capability and reversibility facility is also known as rechargeable energy storage system (RESS) [68]. There are instances where both sources have the reversibility and energy storage facility. For a steady or consistent power supply, MES is usually preferred but for transient power supply and regenerative braking RESS is the best option. The RESS helps in cold start of MES and quick demand of power during acceleration of the vehicle, an in-depth understanding of power density and energy density is needed in order to predict the MES and RESS accurately. Fig. 30 shows the types of energy sources.

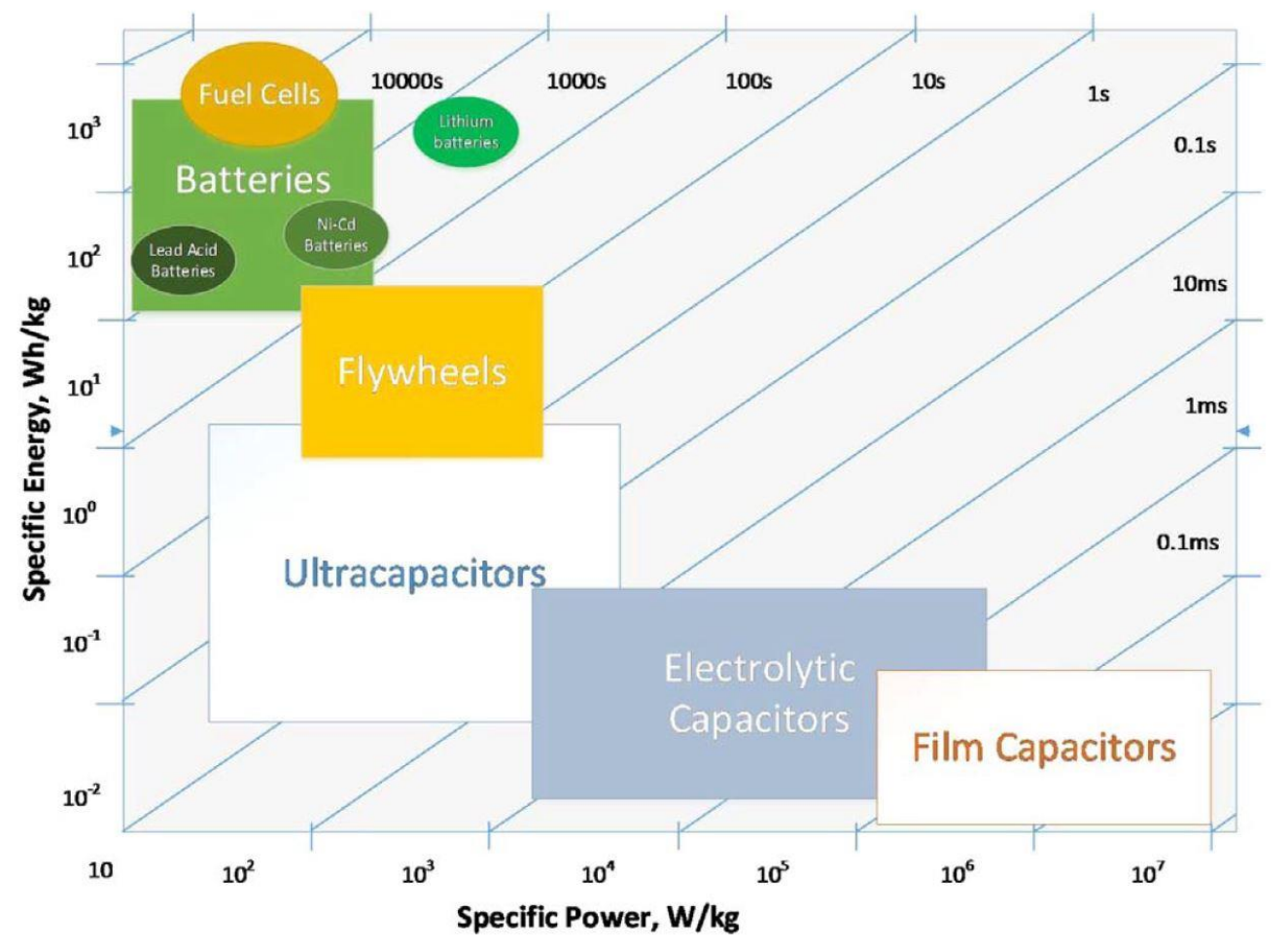

Fig. 30: Specific energy against specific power of ESS [2]

Fig. 30 above shows the specific energy, specific power and time constant. It can be noticed that the energy density of fuel cell and battery is very high but they have low power density. Batteries also have high time constant related to discharge rate. It therefore stipulates that fuel cells and 
batteries are suitable as MES. On the other hand, the different types of capacitors -i.e. ultracapacitor, electrolytic capacitor and thin film capacitors and flywheel- have low energy density (0.001-1 Wh/kg), high power density $(102-107 \mathrm{~W} / \mathrm{Kg})$ and also very high discharge rate. This means these sources can supply high power but the duration is very short. These features make them suitable to be used as RESS. This research explores some storage devices used in FCHEV's as well.

\section{Battery}

As explained earlier, fuel cells operate almost similarly to batteries as both are electrochemical devices for converting chemical energy into electrical energy but while the reactants for the fuel cell are connected externally, that of batteries are already embedded in it. This implies that once the reactants of batteries run out, they can no longer produce electricity but the fuel cell will keep generating electricity so longer as the reactant are constantly being supplied to it externally. Again the electrodes of batteries have the tendency of going into reaction even when the batteries are redundant hence reducing the life span of batteries in general compared to fuel cells. All these are some clear similarities and differences between a battery and fuel cells. A simple description of a battery is a storage device that store electrical energy as chemical energy. Batteries are classified as primary or secondary. The primary types are not rechargeable but the secondary batteries are rechargeable. The secondary types of batteries are preferred for multiple uses especially for vehicular applications. Fig. 31 shows the schematic diagram for a secondary battery. The capacity of batteries is measured in ampere - hour (Ah) and the energy in the batteries is measured in watt - hour (Wh) but the usable state of charge is expressed as a percentage. This explains the availability of charge in the battery. In order to prolong the battery life cycle, it should be kept in a specific state of charge (SOC). The battery capacity is proportional to the maximum discharge current represented by the index $\mathrm{C}$. It indicates that a higher $\mathrm{C}$ value means the fuel cell will deplete faster. The chemical reaction and the temperature of the battery also determine the maximum discharge current. 


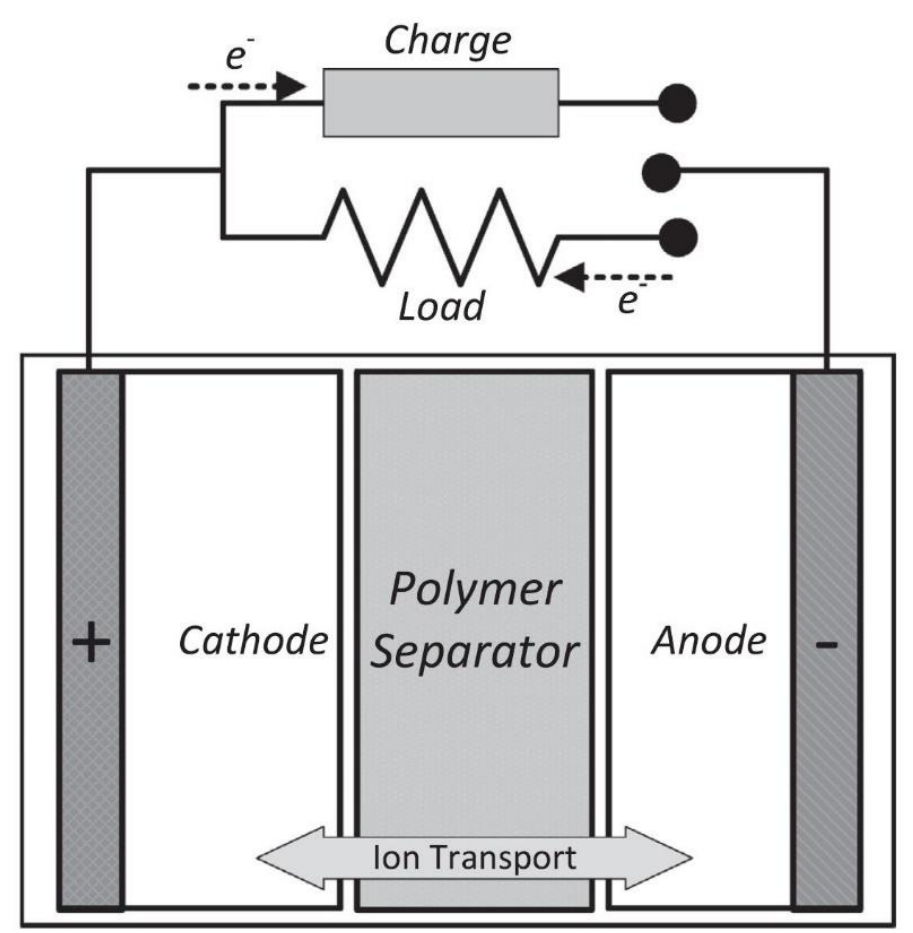

Fig. 31: Diagram of a secondary battery [2]

\section{General Classification and application of battery}

There are various types of batteries with different capacity and characteristics available due to the reliable energy source for long time [69, 70]. There are five main types of batteries for vehicular purposes such as lead acid batteries, nickel batteries, Zinc batteries, lithium batteries and metal air batteries. Table 5 shows the types of battery specifications and applications [71 74]. 
Table 5: Applications and different types of batteries [2]

\begin{tabular}{|c|c|c|c|c|c|c|c|}
\hline Energy storage type & $\begin{array}{l}\text { Specific } \\
\text { energy } \\
(\mathrm{Wh} / \mathrm{kg})\end{array}$ & $\begin{array}{l}\text { Energy } \\
\text { density } \\
(\mathrm{Wh} / \mathrm{L})\end{array}$ & $\begin{array}{l}\text { Specific } \\
\text { power }(W / \\
\text { kg) }\end{array}$ & Life cycle & $\begin{array}{l}\text { Energy } \\
\text { efficiency (\%) }\end{array}$ & $\begin{array}{l}\text { Production cost } \\
(\$ / \mathbf{k W h})\end{array}$ & Application \\
\hline Lead acid battery & & & & & & & \multirow{5}{*}{$\begin{array}{l}\text { Conventional automotive starting, lighting } \\
\text { and ignition, large power backup, grid } \\
\text { energy storage, BEVs, UPS. IC engine } \\
\text { startup. }\end{array}$} \\
\hline Lead acid & 35 & 100 & 180 & 1000 & $>80$ & 60 & \\
\hline Advance lead acid & 45 & - & 250 & 1500 & - & 200 & \\
\hline $\begin{array}{l}\text { Valve regulated lead acid } \\
\text { (VRLA) }\end{array}$ & 50 & - & $150+$ & $700+$ & - & 150 & \\
\hline Metal foil lead acid & 30 & - & 900 & $500+$ & - & - & \\
\hline Nickel battery & & & & & & & \multirow{5}{*}{$\begin{array}{l}\text { Ni-Cd - Two-way radios, emergency medical } \\
\text { equipment, professional video cameras and } \\
\text { power tools. NiMH- Powering portable low } \\
\text { powered devices. Ni-Fe- Off-grid power } \\
\text { system storage. }\end{array}$} \\
\hline Nickel-iron & $50-60$ & 60 & $100-150$ & 2000 & 75 & $150-200$ & \\
\hline Nickel-zinc & 75 & 140 & $170-260$ & 300 & 76 & $100-200$ & \\
\hline Nickel-cadmium (Ni-Cd) & $50-80$ & 300 & 200 & 2000 & 75 & $250-300$ & \\
\hline $\begin{array}{l}\text { Nickel-metal hydride(Ni- } \\
\text { MH) }\end{array}$ & $70-95$ & $180-220$ & $200-300$ & $<3000$ & 70 & $200-250$ & \\
\hline ZEBRA battery & & & & & & & \multirow{8}{*}{$\begin{array}{l}\text { Suitable for automobile applications: cars, } \\
\text { buses and transporters where low } \\
\text { maintenance is needed. } \\
\text { Lightweight and high energy density battery. } \\
\text { Can be used for EVs, portable devices like } \\
\text { laptop, torch, smartphone, camcorder, } \\
\text { digital camera, electronic cigarette, toys. }\end{array}$} \\
\hline Sodium-sulfur & $150-240$ & - & $150-230$ & $800+$ & 80 & $250-450$ & \\
\hline $\begin{array}{l}\text { Sodium-nickel chloride } \\
\text { Lithium battery }\end{array}$ & $90-120$ & 160 & 155 & $1200+$ & 80 & $230-345$ & \\
\hline $\begin{array}{l}\text { Lithium-iron } \\
\quad \text { sulphide(FeS) }\end{array}$ & 150 & - & 300 & $1000+$ & 80 & 110 & \\
\hline $\begin{array}{l}\text { Lithium-iron } \\
\text { phosphate(LiFePO4) }\end{array}$ & 120 & 220 & $2000-4500$ & 42000 & - & 350 & \\
\hline $\begin{array}{l}\text { Lithium-ion } \\
\quad \text { polymer(LiPo) }\end{array}$ & $130-225$ & $200-250$ & $260-450$ & $>1200$ & - & 150 & \\
\hline Lithium-ion & $118-250$ & $200-400$ & $200-430$ & 2000 & 495 & 150 & \\
\hline $\begin{array}{l}\text { Lithium-titanate (LiTiO/ } \\
\text { NiMnO2) }\end{array}$ & $80-100$ & - & 4000 & 18000 & - & 2000 & \\
\hline Metal-air battery & & & & & & & Vehicle propulsion, Grid storage. \\
\hline Aluminum-air & 220 & - & 60 & - & - & - & \\
\hline Zinc-air & 460 & 1400 & $80-140$ & 200 & 60 & $90-120$ & \\
\hline Zinc-refillable & 460 & - & - & - & - & - & \\
\hline Lithium-air & 1800 & - & - & - & - & - & \\
\hline
\end{tabular}




\section{Ultra-capacitors}

The ultra-capacitor is a derivative of conventional capacitor. It is a high density energy storage system. It can be described as a supercapacitor or electrochemical capacitor [75, 76]. Ultracapacitors capacity is measured in Farads (F) but the conventional capacitors are measured in the range of milli-Farads $(\mathrm{mF})$, microfarads $(\mu \mathrm{F})$ and picofarads $(\mathrm{pF})$ [77]. However, the power density of an ultra-capacitor is compromised to increase the energy density. For a conventional capacitor, the power density and energy density are at approximately $10^{12} \mathrm{~W} / \mathrm{m}^{3}$ and $50 \mathrm{Wh} / \mathrm{m}^{3}$ respectively while an ultra-capacitor holds a power density of $10^{6} \mathrm{~W} / \mathrm{m}^{3}$ and an energy density of $10^{4} \mathrm{Wh} / \mathrm{m}^{3}$ approximately [78]. A dielectric material separate two conducting electrode in a conventional capacitor but in an ultra-capacitor the electrodes are enclosed in an electrolyte and parted by a separator between them. The storage of electrostatic charges in the form of ions contributes to the reasons for using electrolytes in ultra-capacitors. Ultra-capacitors have their surface area of the electrode being higher than that of conventional battery or capacitor electrodes. The electrodes absorb the ions and provide much higher charge density than the available capacitors. Again the movement of ions in ultra-capacitors is slower than electrons resulting in higher charging and discharging time than electrolytic capacitors hence the capacity is increased through these means. For the usable energy stored (E) in an ultra-capacitor, Eqn. 5 is used [79]:

$$
E(W h)=\frac{1}{2} \frac{C V_{r}^{2}(3 / 4)}{3600}
$$

Here the $\mathrm{V}_{\mathrm{r}}$ is the rated voltage of the ultra-capacitor cell. Ultra-capacitors are today being preferred compared to batteries because they have high capacity, high efficiency $(>90 \%)$ and high range operating temperature. The first application of ultra-capacitor was in military projects for ignition of battle tank engines and submarines. Due to the advancement of nano-material technology and commercialized manufacturing, the costs of ultra-capacitors have decreased significantly and at the same time capacitance has increased. This has increased the availability of ultra-capacitors. Ultra-capacitors are currently used for diesel engines, locomotives, wind turbines for pitch control, actuators and memory back up. It is also used in regenerative braking applications due to their fast charging ability. 


\section{Characterization and classification of ultra-capacitors}

Ultra-capacitors are categorized under three main categories. These are the Electrochemical Double Layer Capacitor (EDLC), Pseudo-capacitors and Hybrid capacitors. Each class has their own characteristics and system to store charge. The mechanisms are classified as either nonFaradaic, Faradaic or a combination of both. There is transfer of charges between electrodes and electrolyte for Faradaic mechanism. An example of this process is oxidation and reduction reaction. The non - Faradaic process does not comprise any chemical reaction but rather charges are distributed on the surfaces by physical process that does not make or break the chemical bonds [80]. Fig. 32 shows the classification of ultra-capacitors. The chemical properties of different kinds of ultra-capacitors and their application area are given in Table 6 [81 - 83] 


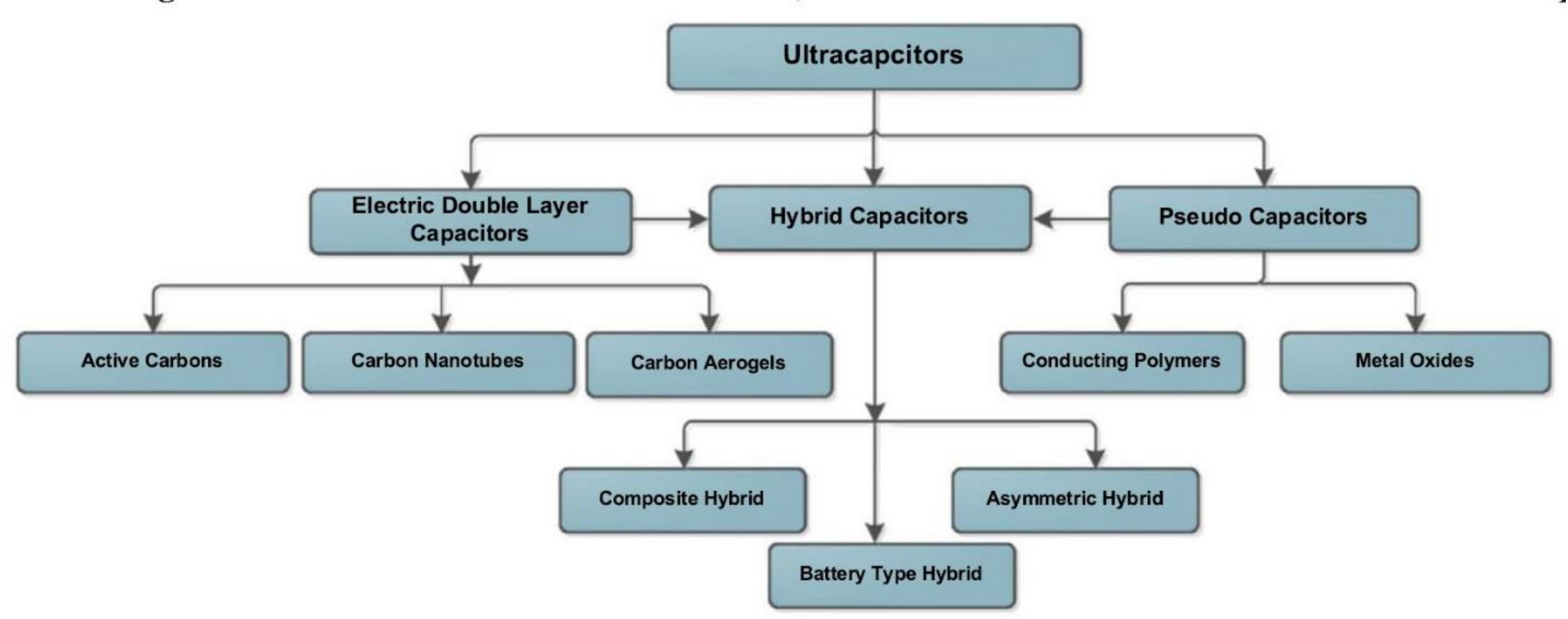

Fig. 32: The various classifications of ultra-capacitors [2] 
Table 6: Various Applications of Ultra-Capacitors [2]

\begin{tabular}{|c|c|c|c|c|c|c|c|c|}
\hline Technology type & $\begin{array}{l}\text { Electrode } \\
\text { materials }\end{array}$ & $\begin{array}{l}\text { Energy storage } \\
\text { mechanisms }\end{array}$ & $\begin{array}{l}\text { Cell } \\
\text { voltages }\end{array}$ & $\begin{array}{l}\text { Energy density } \\
(\mathrm{Wh} / \mathrm{kg})\end{array}$ & $\begin{array}{l}\text { Power density } \\
(\mathrm{W} / \mathrm{kg})\end{array}$ & $\begin{array}{l}\text { Life } \\
\text { cycle }\end{array}$ & $\begin{array}{l}\text { Energy } \\
\text { efficiency }(\%)\end{array}$ & Application \\
\hline Electric double-layer & Activated carbon & Charge separation & $2.5-3$ & $5-7$ & $1-3 \mathrm{M}$ & \multirow[t]{6}{*}{40 years } & \multirow[t]{6}{*}{$>95$} & \multirow{6}{*}{$\begin{array}{l}\text { Engine startup, Hybrid Vehicle power, UPS, powering Toys, GSM } \\
\text { applications, Elevators, cranes or pallet trucks, flashlights, Radars and } \\
\text { torpedoes, defibrillators and cardiac pacemakers, pulsed laser and } \\
\text { welding. } \\
\text { UPS, Low power applications } \\
\text { Satellite phones, digital wireless communication devices, Radars and } \\
\text { torpedoes, aircraft electronic appliances, Space shuttle. }\end{array}$} \\
\hline Advanced carbon & Graphite carbon & $\begin{array}{l}\text { Charge transfer or } \\
\text { intercalation }\end{array}$ & $3-3.5$ & $8-12$ & $1-2 \mathrm{M}$ & & & \\
\hline Advanced carbon & Nanotube forest & Charge separation & $2.5-3$ & - & - & & & \\
\hline Pseudo-capacitor & Metal oxides & Redox charge transfer & $2-3.5$ & $10-15$ & $1-2 \mathrm{M}$ & & & \\
\hline Hybrid Capacitor & $\begin{array}{l}\text { Carbon/metal } \\
\text { oxide }\end{array}$ & $\begin{array}{l}\text { Double-layer/charge } \\
\text { transfer }\end{array}$ & $2-3.3$ & $10-15$ & $1-2 \mathrm{M}$ & & & \\
\hline Hybrid Capacitor & Carbon/lead oxide & Double-layer/faradaic & $1.5-2.2$ & $10-12$ & $1-2 \mathrm{M}$ & & & \\
\hline
\end{tabular}


Due to the high power density EDCL ultra-capacitor is mostly preferred compared to the other types. It is currently being manufactured by most commercial companies. Ness, Asahi Glass, Panasonic, EPCOS, LS cable, Batscap, Power sys and Fuji are some companies manufacturing ultra -capacitors. The performance characteristics of commercial ultra-capacitors have been tested by A Burk [75, 79].

\section{Flywheels Energy Storage (FES)}

Another type of energy storage device is the flywheel energy storage (FES) which utilizes a rotating mechanical device to store or maintain the rotational energy. Energy storage and energy release are the operational mechanisms of flywheel. When torque is applied to a flywheel, energy is stored. The energy is also further released in the form of torque to the connected mechanical device [84]. The stored kinetic energy of a flywheel is given by Eqn. 6:

$$
E_{k}=\frac{1}{2} I \omega^{2}
$$

where $\mathrm{I}$ is the moment of inertia and $\omega$ is the angular velocity.

Flywheel energy storage uses two approaches; mechanical output and electrical output. The mechanical output approach has efficiency of almost double (around 70\%) the electrical output approach. This mechanical output efficiency of FES can be raised up to $97 \%$ and the round-trip efficiency up to $85 \%$ using frictionless magnetic and vacuum bearings [87]. The recent investigation has developed FES systems having $10-150 \mathrm{Wh} / \mathrm{Kg}$ energy and $2-10 \mathrm{~kW} / \mathrm{Kg}$ power density with a lifetime of around 15years [ref]. Lawrence Livermore National Laboratory (LLNL) has built a 100kW FES prototype capable of achieving 1kWh energy at 6000rpm. FES has a diameter of $20 \mathrm{~cm}$ and the length of $30 \mathrm{~cm}$. other research institutes like LLNL in United States, Ashman Tech, AVCON, Northrop Grummen, Power R\&D, Rocketdyne/Rockwell, Trinity Flywheels and UT Austin power Centre are working on to develop high speed FES system for electric vehicles. FES system has the advantage of having long lifetime, low maintenance, quick response, low recharge time and no temperature dependency, which make it suitable for electric vehicle applications [88, 89]. The obstacle faced by FES system for EV

applications are the gyroscopic force management and safety issues [90]. The application area of FES system includes powering road vehicles, rails, rail electrification, UPS, Aircraft launcher 
system, spacecraft energy storage, amusement rides, soft toys, motor sports, wind turbines and grid energy storage [91-93].

\section{Power Conversion topologies of FCHEV applications}

High efficiency and zero emissions always attract researchers to consider fuel cell in the automotive industry compared to other energy sources. The primary aim of most research in the automotive industry is to develop a fuel cell based vehicles that is a very environmentally friendly. The technology being used to integrate fuel cells in vehicles is very expensive but very efficient with quiet operation because it has less number of moving parts. Fig. 33 shows a fuel cell hybrid electric vehicle schematic.

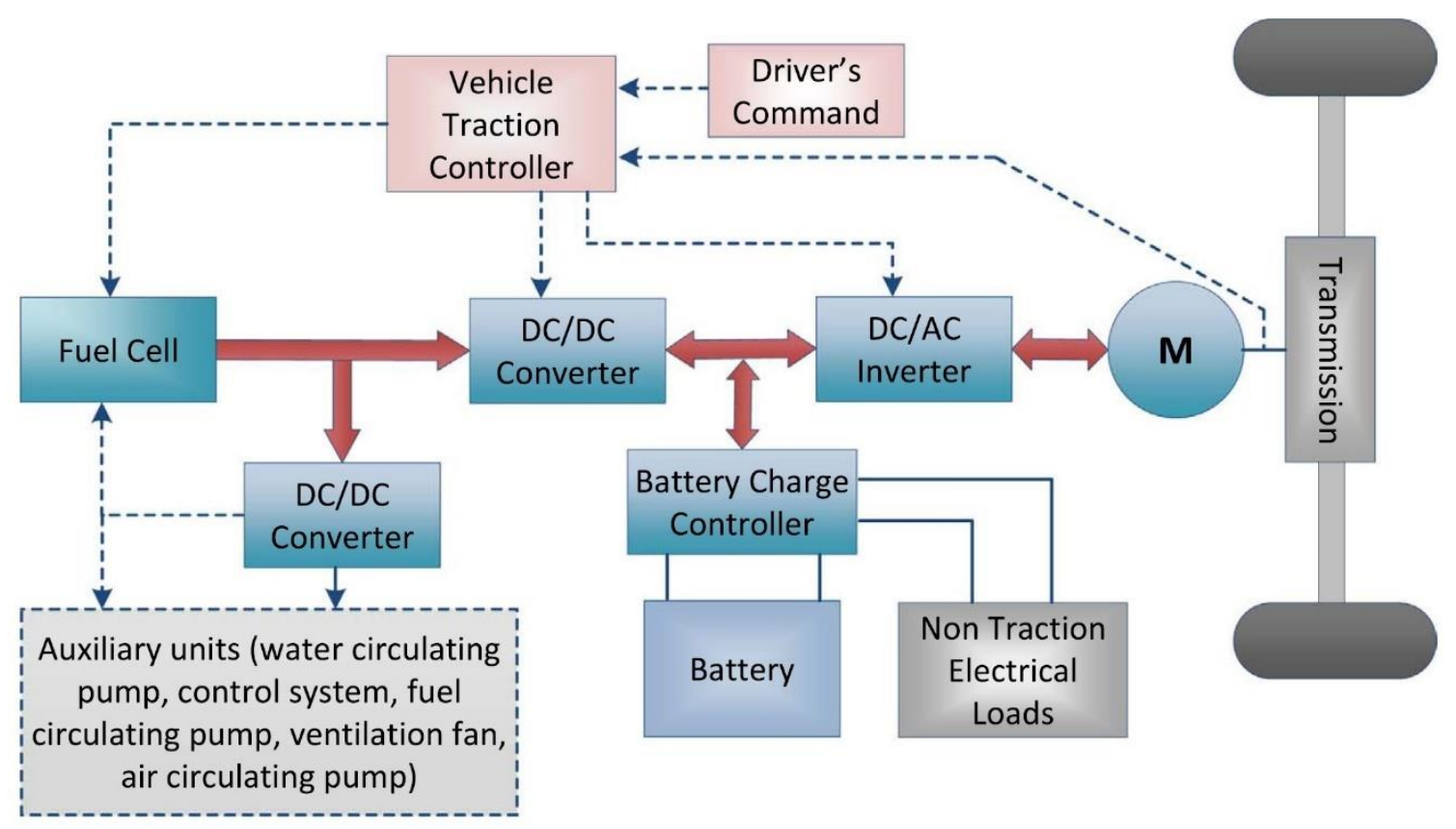

Fig. 33: Fuel cell hybrid electric vehicle [94]

The energy sources from Fig. 33 above are the fuel cell and battery. The fuel cell generates low voltage, which is made usable by two DC/DC converters. One converter sends power to the auxiliary loads such as water, fuel and air pumps, ventilation and control systems while the other converter transfers power to the input DC bus of the traction motor inverter. A bidirectional converter is interfaced to the DC bus by the battery system. The traction motor inverter generates $\mathrm{AC}$ from the DC power supplied by FC and battery and the traction motor uses the AC power in 
producing mechanical output used to move the wheels of the vehicle. The type of arrangement for this system is hybrid utilizing the regenerative braking power of the traction motor. The battery equally functions as the power source during the start-up of the fuel cell initially. When the fuel cell is well heated up, the battery supply is turned off and the system operates on the fuel cell alone. For this type of system ultra-capacitor is not utilized, however, FCHEVs utilize a combination of FC, UC and battery. Depending on the power conversion stages of fuel cell vehicle propulsion system, the configuration can be sub - categorized into two types: multiple stage power conversion and single stage power conversion.

\section{Multiple Stage Power Conversion}

Hybrid vehicles have two stages in their power conversion: the first is the DC-DC conversion and DC-AC conversion. Low voltage DC power from the sources is transformed into high voltage $\mathrm{DC}$ in the first stage and then the high voltage $\mathrm{DC}$ is transformed into AC by inversion. Fig. 34 shows the topographical classification of the multiple stage power conversion [95].

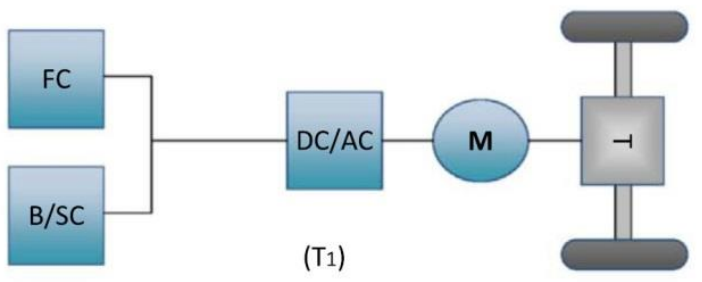

$(\mathrm{T} 1)$

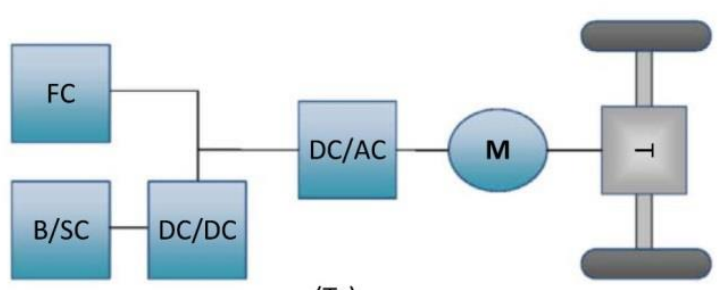

(T3)

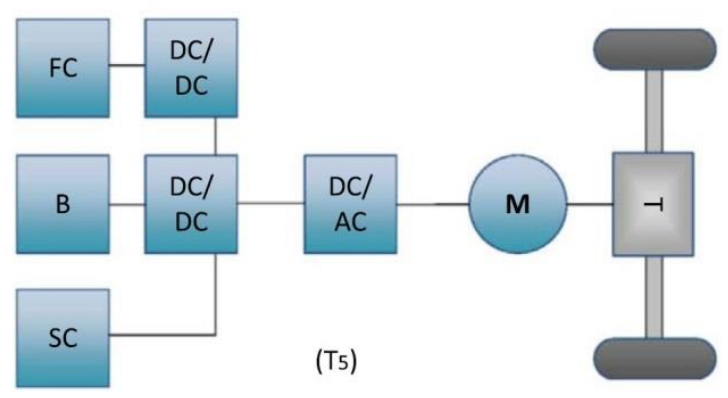

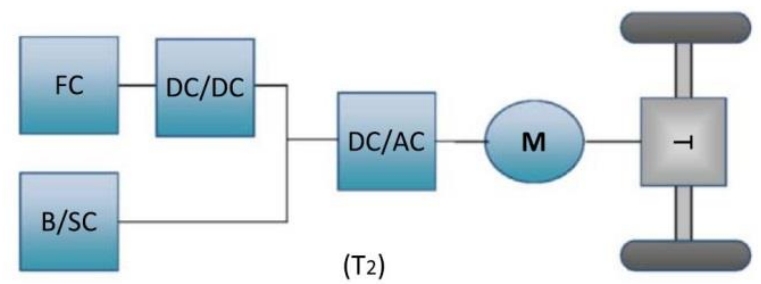

(T2)

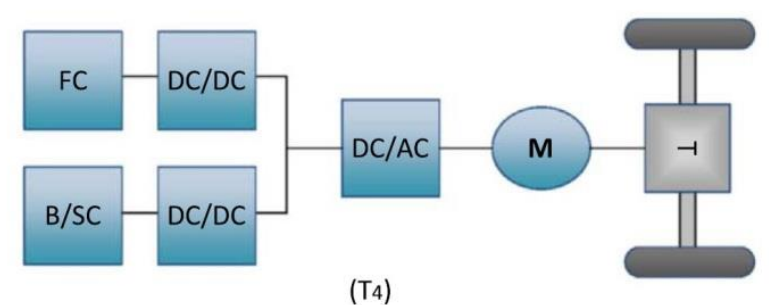

(T4)

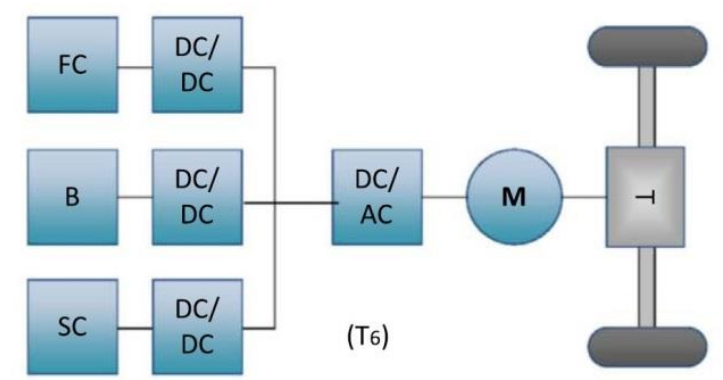


Fig. 34 Topologies of FCHEV (T1) floating DC bus, (T2) Controlled FC with floating battery/ultra-capacitor, (T3) Floating FC with controlled battery/ultra-capacitor (T4) Controlled DC bus with Controlled FC, battery/ultra-capacitor, (T5) Controlled FC with controlled battery and floating ultra-capacitor, (T6) Controlled FC with controlled battery and ultra-capacitor [95].

$\mathrm{T} 1$ is the first topology and it's also the simplest. There is no converter connected to the fuel cell but rather the FC is connected directly with its storage and the combined DC bus is connected to the motor inverter. According to Azib et al [96] finding a reference for this topology is very difficult because it is useful for single stage power conversion. They also proposed this design with a control strategy for FCHEV. Using decoupling strategy and using a Ballard proton exchange membrane fuel cell, Azib et al [96] were able to propose a control strategy. The SC unit has a charger controller and connected directly to the DC bus. With the next topology, FC is connected through a DC/DC converter. The storage system is connected directly to the DC bus and the motor is interfaced through inverter. This type of configuration is accepted in the automotive industry because it helps the power split control over the FC and battery/ultracapacitor. Q. Li et al used a fuzzy controller for energy management of the vehicles [97, 98]. Differently, Tazelaar et al [99] considered a medium size truck as test subject and used equivalent consumption minimization strategy based analytical solution for energy management. From Fig 34, the third topology shows that the storage system is interfaced through a DC/DC converter while the fuel cell is directly connected to the DC bus. The losses in this type of topology are higher compared to T2 because the power through the DC/DC converter is bidirectional here. This means the power electronic loss is higher in this topology. The converter and control strategy of this topology is quite complex. Some models have been recommended in literature [100,101]. An optimal hybrid energy storage system for fuel cell vehicles were proposed by L. Wang et al and their design was made up of a fuel cell, battery and ultracapacitors [100]. The converter control was designed as a one sided asymmetrical phase as well as a duty cycle controller. A maximum fuel economy control strategy was applied for power management [100].

The topology T4 is the commonly preferred option by researchers around the world. It is possible to control both the fuel cell and storage power flow because it is flexible. Tight control of both sources is needed due to the fact that the power of the sources must meet the demanded power 
and the voltage level of the DC bus should be stable. Adding a capacitor in the DC bus will result in the $5^{\text {th }}$ topology.

The $5^{\text {th }}$ topology gives a stable voltage level on DC bus and restricts large voltage swings hence the inverter requirement is flexible. A number of works have been reported in literature on the power control [100-105]. Kisacikoglu et al suggested that load sharing strategy for FC/UC vehicle should use fuzzy logic [102]. The researchers proposed a novel fuzzy logic control algorithm for incorporation into the power conditioning unit of the system. The main focus of the system was to keep the DC bus voltage level stable around the nominal value by determining the fuel cell power demand for propulsion power supply. It also used the braking energy of the motors. Hegazy et al also proposed a fuel cell hybrid control system but the control strategy used particle swarm optimization [103,104]. The model presented by Zheng et al focuses on fuel economy in fuel cell hybrid vehicles $[105,106]$. The strategy used for energy management was equivalent consumption minimization system (ECMS) which would sense the state of charge of the battery system. A rule based control system was also applied to the system, and then the results in terms of fuel consumption were compared with the optimal control system result.

The 5th configuration shows a propulsion system having a battery and ultra-capacitor with fuel cell. A major merit of this propulsion system is that it has both the ultra-capacitor and battery having high power and high energy density. The complexity of this design is its setback. Gao et al researched on a hybrid fuel cell bus made up of a battery and ultra-capacitor with a fuel cell [107]. In order to control the system, fuzzy logic controller is utilized which factors the battery state of charge and ultra-capacitor state of charge into consideration, as well as the required vehicle power as input and gives decision about the power supplied by battery, ultra-capacitor and fuel cell. This topology supports regenerative breaking.

A topology proposed by Li et at [97] was almost the same as fuzzy controlled hybrid architecture type. The battery is also connected with the DC bus directly and the ultra-capacitor also connected through a bidirectional DC-DC converter. Odeim et al applied this topology but made some modification slightly [108]. The FC and UC were interfaced through DC-DC converters and the battery was connected directly to the DC bus in the experiment conducted by Odeim and co-workers. The controller used in the system was proportional integral (PI).

From Fig. 34 the topology (T6) is also made up of fuel cell, ultra-capacitors and battery; all are interfaced through DC-DC converters. This configuration supports the DC bus voltage than the 
other types of topologies. It helps the supercapacitor to handle power and battery to store energy more efficiently in comparison to the $3^{\text {rd }}, 4^{\text {th }}$ and $5^{\text {th }}$ topologies. It enables the supercapacitor to handle power and battery to store energy more efficiently, in comparison to topologies 3 and 5 . A model of energy management system based on wavelet and fuzzy logic was presented by Erdinc et al [109]. The sources of the topology are interfaced through DC-DC converters as shown in topology 6. All the sources of the topology are interfaced through DC-DC converters as shown in topology 6 in Fig. 34. Merlo Perez et al also suggested almost the same configuration based on fuzzy logic control. This was made up of multiple input DC-DC converters instead of three different converters $[110,111]$. Another system was equally proposed by $\mathrm{Yu}$ et al having a global optimization controller also using the same topology [ref]. Table 7 shows some of these topologies 
Table 7: Fuel cell topology summary [2]

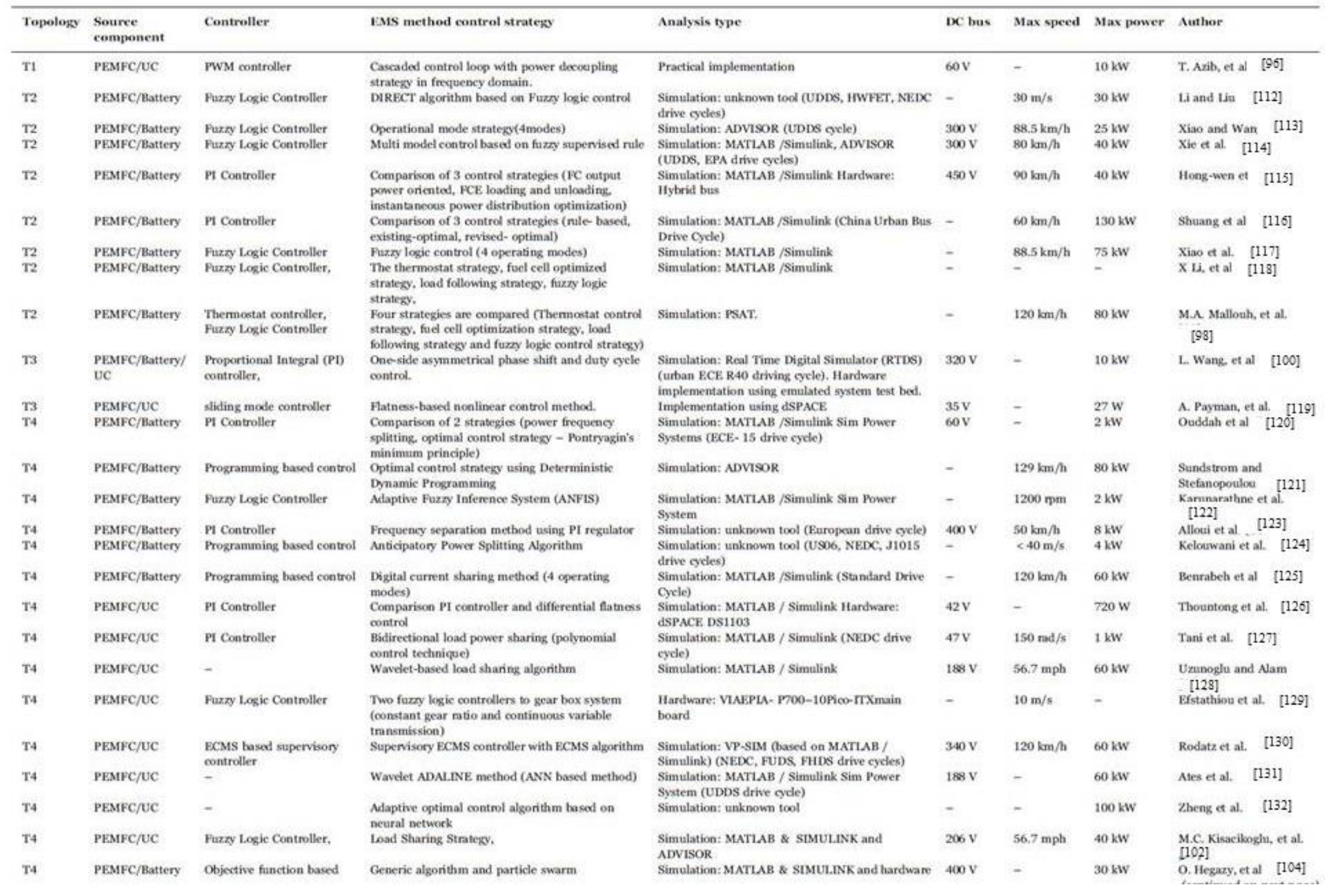

61 | P a g e 


\begin{tabular}{|c|c|c|c|c|c|c|c|c|}
\hline Topology & $\begin{array}{l}\text { Source } \\
\text { component }\end{array}$ & Controller & EMS method control strategy & Analysis type & DC bes & Max speed & Max power & Author \\
\hline & & $\begin{array}{l}\text { eptimization, Rule based } \\
\text { control }\end{array}$ & optimiration, Equivalent fued cossesmption, & implementation using DSP bound & & & & \\
\hline $\mathrm{TA}_{4}$ & PEMFC/Rattery & $\begin{array}{l}\text { PMP based supervisocy } \\
\text { control }\end{array}$ & $\begin{array}{l}\text { Pontrasgin's Minimum Prisciple (PMP) based } \\
\text { algocilhm is compared watb dynamic programming } \\
\text { approsch. }\end{array}$ & $\begin{array}{l}\text { Simulation: MATIAB \& SIMUUNK (drining } \\
\text { cyde: FTP72 urban, NEEC 2000, and Japan 1015) }\end{array}$ & - & - & $62 \mathrm{~kW}$ & $\begin{array}{l}\text { C.ll. Zheng ef al. } \\
\text { [104.105] }\end{array}$ \\
\hline Ts & $\begin{array}{l}\text { PEMFC/Battery' } \\
\text { UC }\end{array}$ & Fuxxy Legic Controlker & Type- 1 fuxxy logic controller & $\begin{array}{l}\text { Hardware: ECCF vehiche (electrial chain } \\
\text { cumpooent exaluatioa) }\end{array}$ & $560 \mathrm{~V}$ & $20 \mathrm{~km} / \mathrm{h}$ & $40 \mathrm{KW}$ & Martinez ef al [133] \\
\hline T5 & $\begin{array}{l}\text { PEMFC/Battery/ } \\
\text { UC }\end{array}$ & Fuxxy Logic Controller & $\begin{array}{l}\text { Comparison of fuxxy logic in fued oell-battery (FC- } \\
\text { B) and fuel cell-battery-supertaparitor(FC-B-SC) } \\
\text { HEV }\end{array}$ & $\begin{array}{l}\text { Simulation: MATLAB /Simulink, ADVISOR } \\
\text { (UDDS, HWFET, USO6, ECE+EUDC drive cydes) }\end{array}$ & - & $160 \mathrm{~km} / \mathrm{h}$ & $40 \mathrm{~kW}$ & Liet al. [97] \\
\hline T5 & $\begin{array}{l}\text { PEMFC/Battery/ } \\
\text { DC }\end{array}$ & $\begin{array}{l}\text { Fuzzy Logic Controller, P1 } \\
\text { ccentrolles }\end{array}$ & 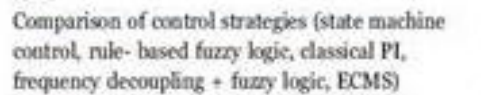 & $\begin{array}{l}\text { Simulation: MATLAB / Simulink Sim Power } \\
\text { System Hardware: N1-PXEsic8 }\end{array}$ & $280 \mathrm{~V}$ & - & $<12 \mathrm{~kW}$ & Matopan et al | [134] \\
\hline Ts & $\begin{array}{l}\text { PEMFC/Battery/ } \\
\text { UC }\end{array}$ & fuxsy kgik controlles, & $\begin{array}{l}\text { Member function based Furry logic control } \\
\text { strategy. }\end{array}$ & Practical implementation. & $400 \mathrm{~V}$ & $23.4 \mathrm{~km} / \mathrm{h}$ & $120 \mathrm{~kW}$ & D. Gao, et al: [107] \\
\hline T6 & $\begin{array}{l}\text { PEMEFC/Battery/ } \\
\text { UC }\end{array}$ & FI Contmaller & Operational mode control (7 operational states) & $\begin{array}{l}\text { Simulation: MATLAB / Simmlink (ECE-47 test } \\
\text { drive cyde) }\end{array}$ & $120 \mathrm{~V}$ & $47 \mathrm{~km} / \mathrm{h}$ & $<3 \mathrm{~kW}$ & Hannan et al \\
\hline To & $\begin{array}{l}\text { PEMFC/Battery/ } \\
\text { UC }\end{array}$ & if Contmoller & 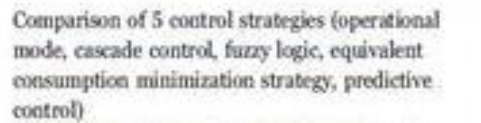 & $\begin{array}{l}\text { Simulation: MATLAB / Sinsulink Sim Power } \\
\text { System. Hardnare: Urbas3 (urban street railnay) }\end{array}$ & $750 \mathrm{~V}$ & $30 \mathrm{~km} / \mathrm{h}$ & $400 \mathrm{~kW}$ & Garcia et al. | [136] \\
\hline T6 & $\begin{array}{l}\text { PEMFC/Battery/ } \\
\text { UC }\end{array}$ & Thernostat control & $\begin{array}{l}\text { Comparisson of optimal costrol strategies with } \\
\text { thermostatic eoetrol strategy }\end{array}$ & $\begin{array}{l}\text { Simulation: MATLAB / Simulink (UDDS, USa6 } \\
\text { dritre cycks) }\end{array}$ & $300 \mathrm{~V}$ & $128 \mathrm{~km} / \mathrm{h}$ & $100 \mathrm{~kW}$ & Yuetal [111] \\
\hline T6 & $\begin{array}{l}\text { PEMFC/Battery/ } \\
\text { UC }\end{array}$ & - & $\begin{array}{l}\text { Traction coetrol strategy esing simulation code } \\
\text { ECOS, mult objective genetic algorither is used. }\end{array}$ & $\begin{array}{l}\text { Simulation: MATLAB / Sirsulink (NEDC, UDDS, } \\
\text { HWFET } 1015 \text { drive cydes) }\end{array}$ & $48 \mathrm{~V}$ & - & $60 \mathrm{~kW}$ & Paladiniet al [137] \\
\hline T6 & $\begin{array}{l}\text { PEMFC/Battery/ } \\
\text { UC }\end{array}$ & Furxy Logic Controlkes & Flatness control technique and furzy logic coetrol & $\begin{array}{l}\text { Simulation: MATLAB /Sirsulink Handware: } \\
\text { ASPACE and PC test bench }\end{array}$ & $42-48 \mathrm{~V}$ & - & $780 \mathrm{~W}$ & Zandi et al [138] \\
\hline T6 & $\begin{array}{l}\text { PEMFC/Battery] } \\
\text { UC }\end{array}$ & Progranming based control & Simple-rule based stratey & Simulation: MATLAB / Simulink Proedesign & $300 \mathrm{~V}$ & $120 \mathrm{~km} / \mathrm{h}$ & $58 \mathrm{~kW}$ & Lia et al [139] \\
\hline To & $\begin{array}{l}\text { PEMFC/Battery/ } \\
\text { UC }\end{array}$ & fuxxy lagic controller, & Maltiple input coeverter, Furzy logic coetrol, & $\begin{array}{l}\text { Simulation- MATLAB \& SIMUUNK and Sim } \\
\text { Power System (driving oyde: UDDS drime ovde). } \\
\text { Practical implementatiog. }\end{array}$ & $400 \mathrm{~V}$ & - & $38.5 \mathrm{~kW}$ & A Merlin-Perez, et al. \\
\hline
\end{tabular}

62 | P a g e 


\section{Single stage power conversion}

The two stage power conversions makes the converters too big, very expensive and reduce the efficiency of the converters hence the sudden drift by researchers to focus on the possibility of relying on single stager power converters. A single stage power converter was suggested in some literature validating the possibility of supplying the needed output power by maintaining input sources in good health. Fig. 35 shows the generalized schematic diagram of single stage power conversion such as voltage source inverters (VSI), current source inverters (CSI), switched boost inverters (SBI), Z-source inverters (ZSI) and differential boost (DBI) inverters.

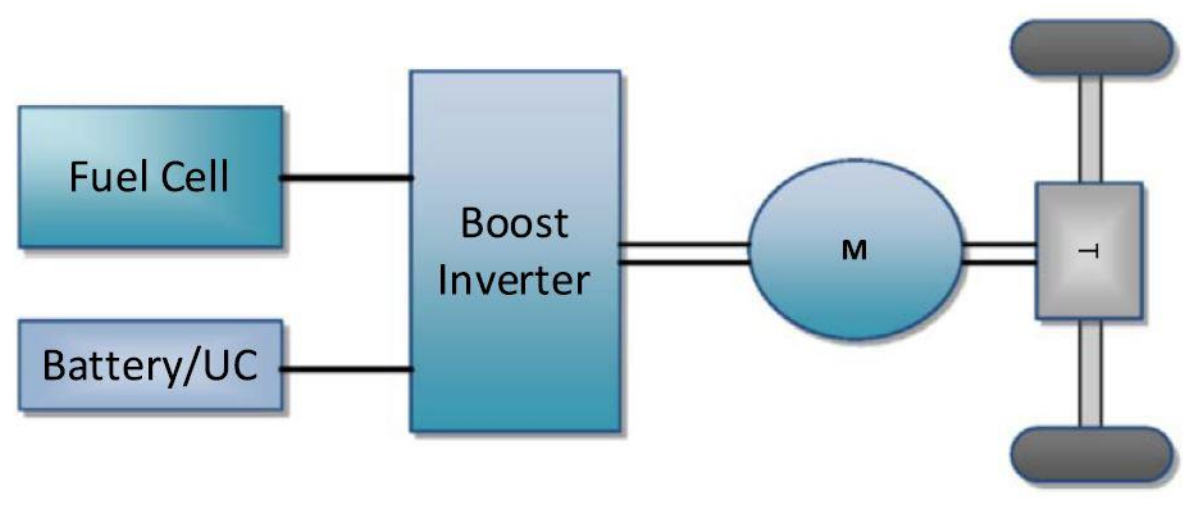

Fig. 35: Single stage power conversion of an FCHE [2]

There are some limitations for the VSI and CSI. They cannot be used in some applications. For instance, VSI cannot boost AC output voltage and CSI cannot lower the voltage level [140]. This means it is impossible for them to function independently. Again they cannot be interchanged and EMI noise affects both converters operation. The switching device and motor connected to VSI or CSI face higher stresses, thus the motor's constant power speed ratio is reduced. The switched boost inverter (SBI) is another type of inverter which uses DC-DC boost inversion system. It can serve the purpose of a single stage boost inverter although it is not a pure single stage. The circuit diagram of SBI is shown in Fig. 36 [141]. It normally has two parts i.e. the boost part and the inverter part. The boost part consists of an inductor and a switch as well as a diode which increases the DC voltage level and then the full bridge inverter which transforms the $\mathrm{DC}$ voltage into AC. The inverter is based on high speed switching and this makes the output require a filter to achieve pure sinusoidal AC voltage. Thus an LC filter is added to the topology. 
There has been different modification done on this design in recent times. The $\mathrm{Z}$ source inverter can overcome the limitations of VSI and CSI through maintaining the size smaller than the DCDC boosted PWM inverter.

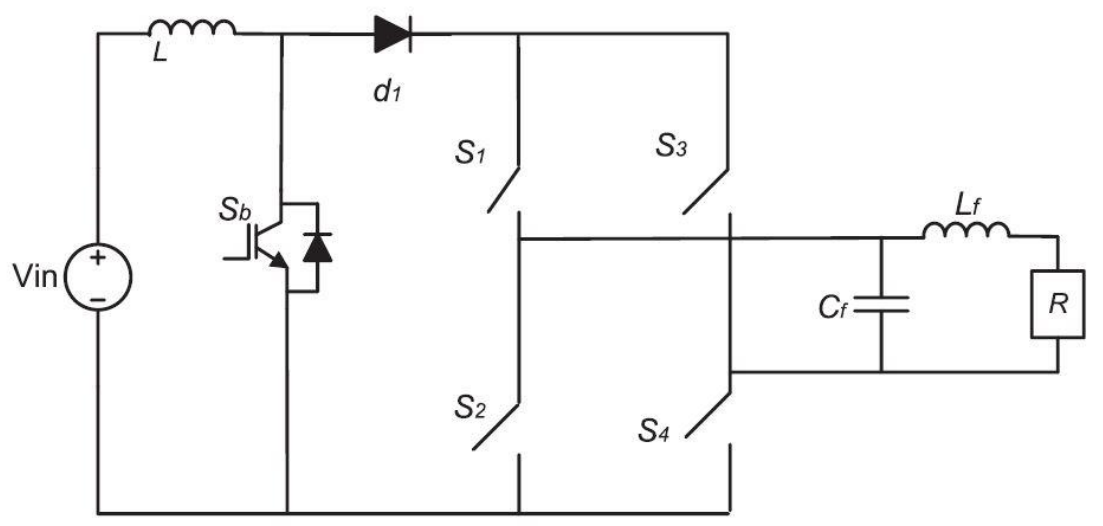

Fig. 36: Switch boost inverter design [142]

The $\mathrm{z}$ source inverter often generates the necessary voltage level for traction motor by observing the state of charge of the battery and the output power controlling it at the same time but for a low boost ratio range and the switching device has a lower power. The size and cost of the converter increase due to the increment of the LC impedance $[143,144]$.

The $\mathrm{Z}$ source inverter for fuel cell is depicted in Fig. 37

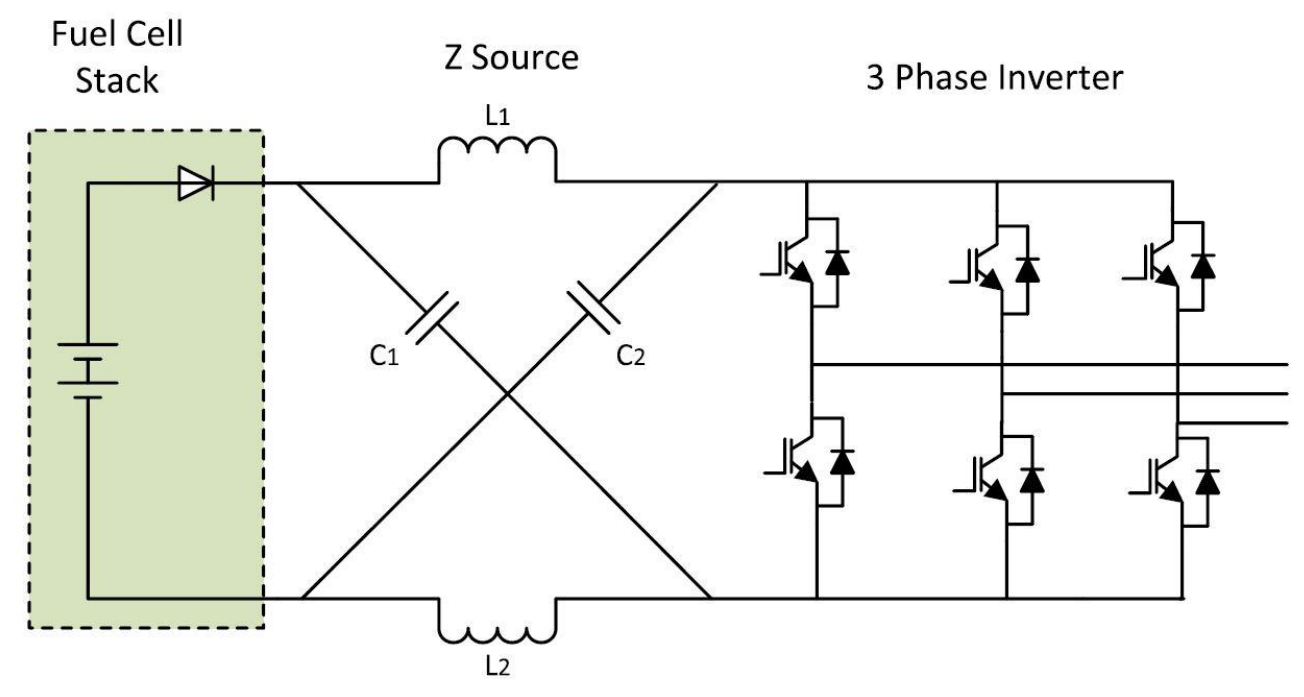

Fig. 37: The $\mathrm{Z}$ source inverter for fuel cell [145] 
A differential boost inverter is used in instances where a low input voltage and high boost ratio is required. This is basically because the differential boost inverter has a high boost ratio more than 2. The boost type inverter is preferred for a single stage converter because it can perform both boosting and inversion. The only challenge with this type of converter is the fact that only a source is connected at any particular point in time. Special arrangement is required in order to connect multiple sources. Fig. 38 shows the different types of differential boost inverter.

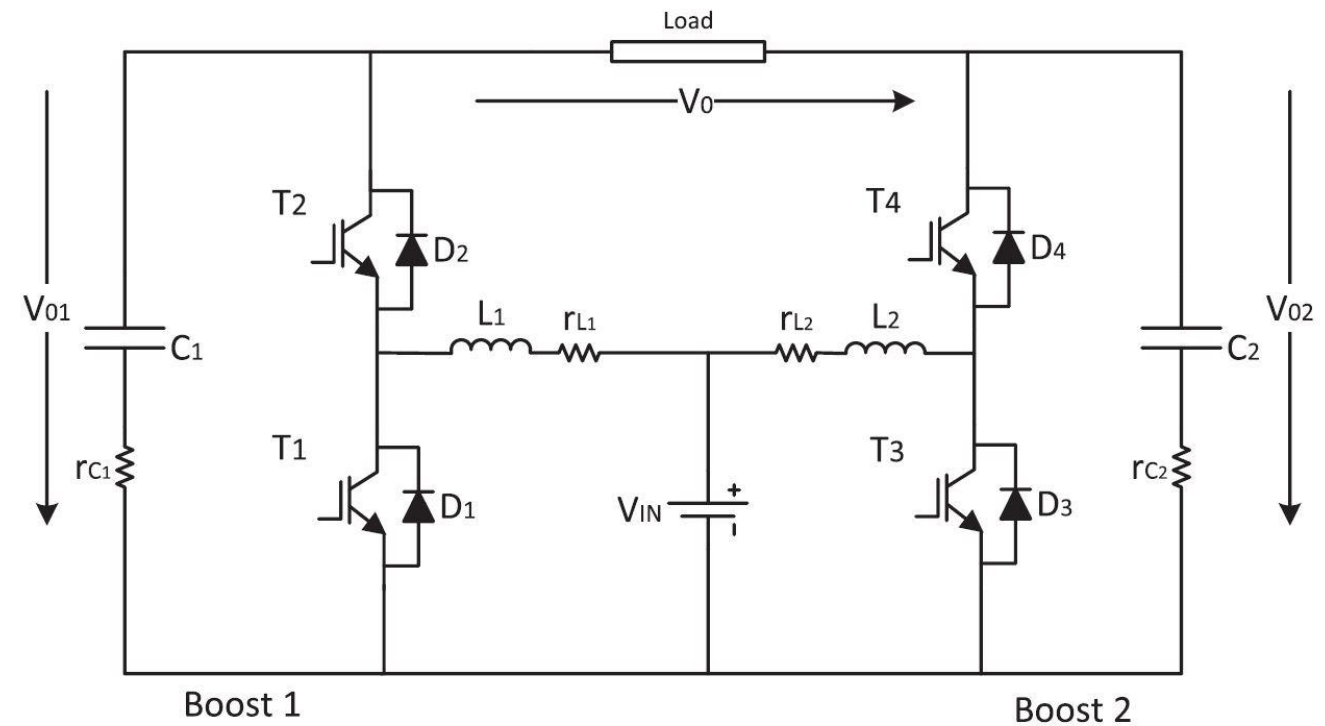

Fig. 38: Different boost inverter system with single source

The control system is the main challenge using this type of topology. Researchers around the world has suggested different control methods for this specific differential boost inverter among which PWM [146], sliding mode control [147-151] and dual loop control [152-163] are well known. Other control methods have also been suggested, like the fuzzy rule based neutral network control and adaptive control [164,165]. Also nonlinear feedback linearization technique [165], current feedback technique [155] and linear multiple input or the multiple output control strategy [166-170] were suggested. Several modifications of the DBI topology recently are being investigated as well. The multiple input, single stage DC-DC and DCAC converter were proposed by Danyali et al [167]. 


\section{Comparison between Fuel cell vehicles and Electric car}

Comparing with conventional engines, fuel cell vehicles seems to have higher fuel efficiency due to direct conversion from chemical energy to electrical energy. The overall efficiency of fuel cell from wheel to tank and tank to wheel can be as high as $40 \%$, over $15 \%$ higher than current hybrid car. Table 8 from Fangzhu and Philip [85] shows a clear difference between FHEV and Hybrid cars. The table differentiates between E6 model made by BYD Company as an example of an electric car and the FCX Clarity made by Honda as example of fuel cell car. From Table 8, the curb weight of the FCX clarity fuel cell car is lighter and refill time is also faster compared to the BYD E6. The energy storage could reach up to $136 \mathrm{kWh}$ for fuel cell car. Thus it has a huge potential for future transportation application. Due to the uncertainty of the technology and infrastructure, it is very difficult to predict when and how many might be on the road in the next few years.

Table 8: Comparison between an Electric Car and a Fuel cell hydrogen car

\begin{tabular}{|l|l|l|}
\hline Vehicle type & Electric car & Example \\
\hline Exal cell hydrogen car \\
\end{tabular}

The application of hydrogen can be experienced in several devices like bicycle, boat, passenger car, bus and even the space rocket. It provides a very sustainable transportation choice for the future. Automotive firms today are still upgrading this useful technology to come out with very competitive price to increase the number of FHEV on the automobile industry market. 
According to Ahn and Lim [86], most car makers were known to be active in the development of fuel cell vehicles including Honda, Toyota and Ford -as listed in Table 9- had plans a decade ago to build highly efficient fuel cell cars. There were specific steps they had to embark on to make that giant step a reality. The Honda FCX Clarity was able to deliver the same performance as conventional vehicles. Honda went further in delivering the FCX mode to specific customers in the US and Japan. The company selected a dealer network near to hydrogen fuelling stations purposely for servicing the vehicles. The company agreed that these vehicles could be bought on lease with 36 month period at $\$ 600$ per month [49]. During that same period, BMW extensively promoted its Hydrogen 7. It was based on a regular 7- series model with a hydrogen internal combustion engine that can run both on petrol and hydrogen. Korean OED Kia Hyundai Automotive Group has developed the fourth generation Kia Borrengo fuel cell SUV for road tests in California and Korea. Hyundai started the production of the i-blue in 2012. 
Table 9: Several reported fuel cell vehicle developments [40].

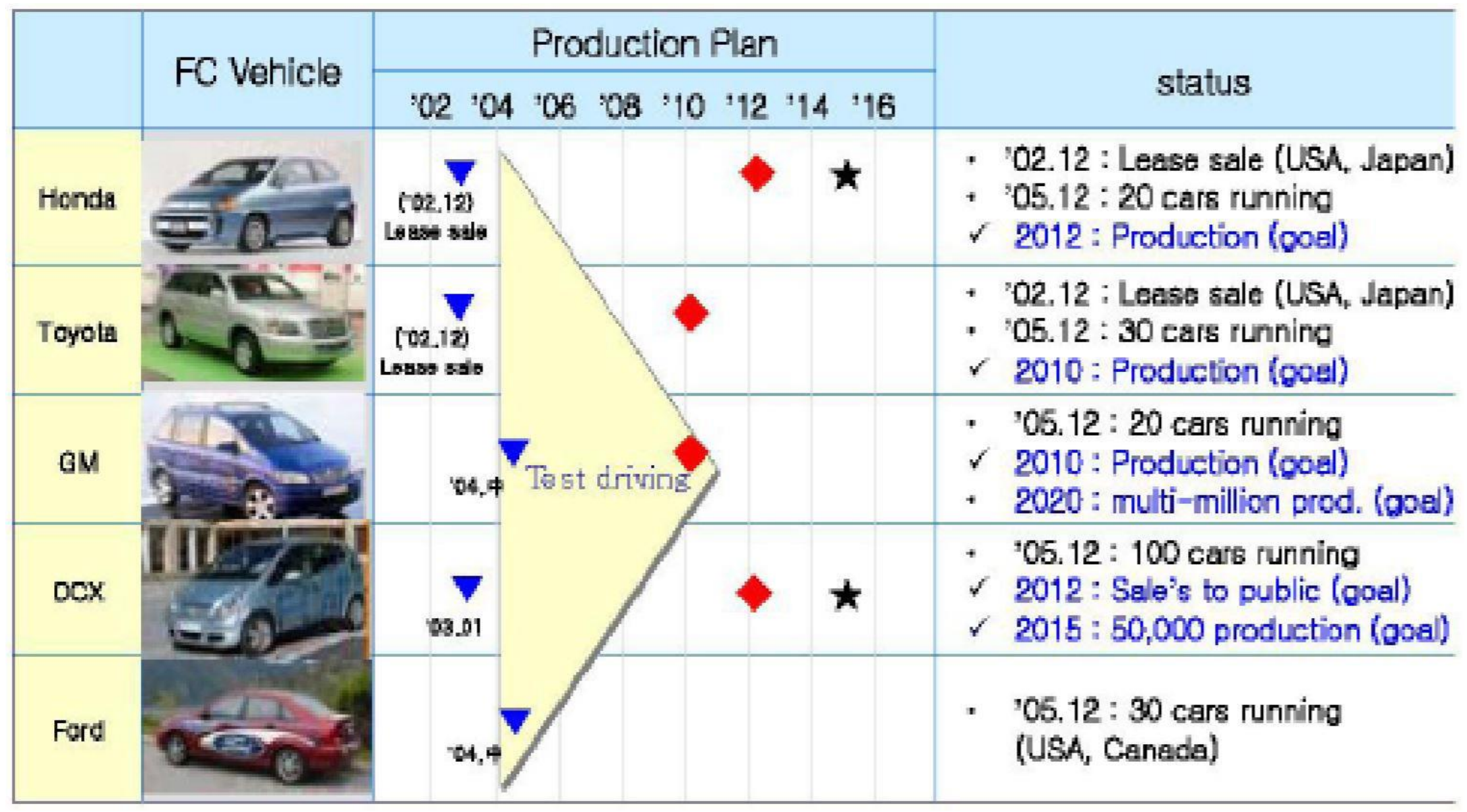


The oak Ridge National Laboratory did a scenario analysis of three fuel cell vehicle penetration rates to assess the costs and infrastructure needs to meet growth to two, five and ten million of fuel cell vehicles in the US by 2025 [171]. This analysis concluded that with specific deployment policies in place during 2012 - 2025, the fuel cell vehicle market share could grow to $50 \%$ by 2030 and $90 \%$ by 2050 . Fuel cell stations in regions where the vehicle would be sold will greatly affect the purchase of the fuel. A conceptual roadmap plan was illustrated by California Fuel Cell Partnership (CaFCP) in 2008. The commercialization includes technology introduction (2007 2010), pre-commercial stage (2011-2013) and early commercial stage (2014 - 2016). The technology refinement and early market preparation could be tested in a couple of regions such as California and New York and then commercial deployment into the mass market will be conducted in other metropolitan regions. Tables $10-13$ show the various pros and cons of FHEV, HEVs and PHEVs.

Table 10: Fuel Cell Electric Vehicle (FCEVs)

\begin{tabular}{|l|l|}
\hline Pros & Cons \\
\hline Zero tailpipe emissions & Cost reduction \\
\hline $\begin{array}{l}\text { Higher energy efficiency than the internal } \\
\text { combustion engine }\end{array}$ & Increased reliability and durability \\
\hline $\begin{array}{l}\text { Regenerative braking captures and reuses } \\
\text { braking energy }\end{array}$ & $\begin{array}{l}\text { Hydrogen generation, distribution, dispensing } \\
\text { and on-board storage }\end{array}$ \\
\hline $\begin{array}{l}\text { Potential of near - zero well - to - wheel } \\
\text { emissions when using renewable fuels to } \\
\text { produce hydrogen }\end{array}$ & $\begin{array}{l}\text { Availability and affordability of hydrogen } \\
\text { refuelling }\end{array}$ \\
\hline No dependence on petroleum & Codes and standards development \\
\hline & Consumer education \\
\hline
\end{tabular}


Table 11: Hybrid Electric Vehicles (HEVs)

\begin{tabular}{|l|l|}
\hline Pros & Cons \\
\hline Optimized fuel efficiency and performance & Higher initial cost \\
\hline Lower fuelling costs & Complexity of two power trains \\
\hline $\begin{array}{l}\text { Reduced fuel consumption and tailpipe } \\
\text { emissions }\end{array}$ & $\begin{array}{l}\text { Component availability - batteries, power } \\
\text { trains, power electronics. }\end{array}$ \\
\hline Recovered energy from regenerative braking & \\
\hline Use of existing gas station infrastructure. & \\
\hline
\end{tabular}

Table 12: Plug - in Hybrid Electric Vehicles (PHEVs)

\begin{tabular}{|l|l|}
\hline Pros & Cons \\
\hline Cleaner electric energy & Cost and complexity of two power trains \\
\hline $\begin{array}{l}\text { Reduced fuel consumption and tailpipe } \\
\text { emissions }\end{array}$ & $\begin{array}{l}\text { Component availability - batteries, power } \\
\text { trains, power electronics. }\end{array}$ \\
\hline $\begin{array}{l}\text { Energy security by displacing imported } \\
\text { petroleum with domestic generated electricity }\end{array}$ & Higher initial cost \\
\hline Optimized fuel efficiency and performance & Cost of batteries and battery replacement \\
\hline Recovered energy from regenerative braking & Added weight \\
\hline Unchanged gas station infrastructure & \\
\hline Grid connection potential & \\
\hline $\begin{array}{l}\text { Potential of even lower fuelling costs } \\
\text { compared to battery sustaining hybrids. }\end{array}$ & \\
\hline Pure zero - emission capability & \\
\hline
\end{tabular}


Table 13: Battery Electric Vehicles (BEVs)

\begin{tabular}{|l|l|}
\hline Pros & Cons \\
\hline $\begin{array}{l}\text { Use of cleaner electric energy produced } \\
\text { through advanced technologies or renewable }\end{array}$ & Mileage range \\
\hline Zero tailpipe emissions & Battery technology still to be improved \\
\hline Overnight battery recharging & Need for public recharging infrastructure \\
\hline Recycle energy from regenerative braking & \\
\hline Lower fuel and operational cost & \\
\hline Quiet operation & \\
\hline
\end{tabular}




\section{Challenges of the fuel cell technology}

Fuel cell technology keeps advancing at a fast pace with more prototypes being continuously developed. Europe and the USA have enjoyed this valuable technological development over the last few decades and continue to propagate its further advancement in the automobile industry. However, the commercialization of this technology still remains a challenge. The cost of fuel cells is one of the big challenges the industry faces as well as other issues such as the durability of the unit, hydrogen infrastructure and hydrogen storage. All these issues continue to impede the advancement of this promising clean technology.

\section{Fuel Cell Cost}

The fuel cell is one of the most promising products of the $21^{\text {st }}$ Century as it continues to compete with batteries, the internal combustion engine and power grid in terms of high efficiency. The cost of a fuel cell is influence by three factors: material and components costs, labour for design and fabrication, and capital cost of the manufacturing equipment and facilities [172, 173]. Labour and capital cost can be reduced through mass production. Material and components costs such as catalysts, membrane and bipolar plates are dependent on technology innovations and the market $[174,175]$. According to the Carbon Trust, in order to be competitive with internal combustion engine vehicle, automotive fuel cells must reach approximately $\$ 36 / \mathrm{kW}$. Platinum (Pt) which is used as the catalyst is a rare metal with an annual production rate of around 250 tonnes. It is currently mined in South Africa, Russia and North America. Estimated world reserves of $\mathrm{Pt}$ are greater than 30,000 tonnes. Due to the high value of platinum, it can be recycled at the end of the life of the vehicle [176]. Technology developments that could reduce the cost of recycling of platinum or reduces the quantities used will eventually affect the cost of the fuel cells. Other advances such as increasing power density, reducing system complexity and improving durability will also lead to reduced costs. A reduction of the platinum found on the catalyst layer will affect the general cost of the fuel cell and help in the mass production especially in the transport industry [177]. The amount of platinum can be reduced by using Pt alloy catalyst or by the application of core shell catalysts. Platinum alloy catalyst is simply an alloy of platinum with a lower cost metal(s) such as rhenium $(\mathrm{Ru})$ or Chromium $(\mathrm{Cr})[178,179]$. The core shell catalysts are nanoscopic low cost metal cores such as copper and rhenium covered by a platinum shell. Platinum contents of fuel cells were reduced by more than doubling catalyst 
specific power from the 2008 baseline of $2.8 \mathrm{Kw} / \mathrm{g}$ of platinum group metal (PGM) to $5.8 \mathrm{~kW} / \mathrm{g}$ in 2012. Current catalyst specific power is approaching the 2017 target of $8.0 \mathrm{~kW} / \mathrm{g}$ and it reflects more than 80 percent reduction in PGM content since 2005. Several UK organizations are focused on achieving a step-change in PEM fuel cell system costs by developing technologies that reduce platinum use, increase power densities and radically simplify system designs. Today there are several calls to develop platinum free catalyst as a means of reducing the cost of the fuel cell. Metals such as cobalt $(\mathrm{Co})$ and Iron $(\mathrm{Fe})$ were used as alternative to Platinum as the catalyst in PEMFC technology. ACAL Energy patented FlowCath [180] fuel cell design that uses a liquid polymer cathode solution which replaces the platinum-based solid cathode used in standard PEM fuel cells. ITM power also made another patent to demonstrate high power densities by replacing the perfluorosulfonic acid membranes that are the current industry standard with a membrane fabricated using ionic polymers. High power densities are translated more into more power per cell; hence much smaller, lighter and cheaper stack can meet the same power output requirements. The initial proposed fuel cell by ITM Power fuel cell was $35 \$ / \mathrm{kW}$. Imperial college has patented a new fuel cells stack design [181]. The flexi planar design they patented uses a layered arrangement of laminated, printed circuit board materials, bonded on top of each other to create a fuel cell stack with internal fuel, water and air channels.

\section{Durability and Performances}

Accumulation of degraded materials and catalyst due to water and heat issues often leads to low durability and reliability $[182,183]$. Issue relating to poor water management always affects the performance of the fuel cell adversely. Fuel and oxidant starvation as well as corrosion and chemical reactions of cell components that cause dehydration or flooding lead to the degradation of materials in the fuel cell. The dehydration can damage the membrane and flooding can facilitate corrosion of electrodes, the catalyst layers, the gas diffusion media and the membrane. Controlling flow conditions like humidity, flow rates and temperature can affect the lifetime of fuel cells. Developing cheap and high corrosion resistant bipolar plates is one of the means of enhancing the mechanical durability of the PEM fuel cells. Most fuel cells bipolar plates are made up of graphite due to their ability to resist corrosion and their high surface conductivity in the PEM fuel cell environment. Though this useful characteristic of graphite makes it a suitable 
option for the fuel cell industry, its brittle nature doesn't make it suitable for transport applications where lots of vibrations and loadings occur. Metals, metal alloys and carbon based composites have been suggested recently to develop cost effective and durable bipolar plates which can replace the graphite ones $[184,185]$. The advantages of metals over carbon based composites for fuel cells used in transport application are numerous as they possess higher mechanical strength and can be made thinner to achieve higher power density and better durability [186]. It was found that bare metals such as stainless steel, aluminium, titanium and nickel are susceptible to corrosion [187]. The corrosion behaviour of metallic flow plates causes many undesirable phenomena such as increasing the electrical resistance and decreasing the efficiency and power output of the fuel cell [188, 189]. Two main classifications of coatings, carbon-based and metal-based, have been investigated in the past decade [190]. Carbon based coatings include conductive polymers (e.g., Polyanille (PANI) and polypyrrole (PPY) [191]), graphite [192], and composite coating (e.g., TiC-ETFE, Ag-PTFE [193, 194]). The metal base coatings for bipolar plate applications include Noble metals [74], metal nitrides [195 - 197] and metal carbides [198, 199] and conductive metal oxide such as fluorine doped Tin (II) oxide $\left(\mathrm{SnO}_{2}: \mathrm{F}\right)$ and Ruthenium oxide $\left(\mathrm{RuO}_{2}\right)$ [200, 201]. The carbon erosion in the catalyst layer was considered as a major degradation source in operating a PEM fuel cell. The most promising electro-catalyst applied on PEMFC is the platinum nanoparticles supported on carbon black $(\mathrm{Pt} / \mathrm{C})$. However, platinum nanoparticles in catalyst layers must have simultaneous access to the gases, electrons and protons to be effectively utilized as catalysts. The platinum nanoparticles in the thin catalyst layers may detach from the carbon support and accelerate the degradation of the electrochemical performance when they are operated under high temperature. It was established that a mixture of graphene with conventional Pt/C was able to transport electrons effectively and provide better pathways under high current density condition [202]. Graphene can potentially provide much higher durability than carbon black with its unique graphitized basal plane [203]. To facilitate efficient ionic conductivity, some minimum level of hydration is needed in the proton exchange membrane. However excess hydration will be related to reliability problems such as voltage loss at high current density, voltage instability at low current density, unreliable start-up under freezing conditions and will promote the degradation of the carbon in the catalyst support due to hydrogen starvation [204]. Therefore, the design of the membrane and its material selection must meet the critical balance between too little and too much hydration, especially for 
automotive applications where the fuel cell can be subjected to wide variations in load demand and ambient conditions during its lifetime. Another means of improving a fuel is through the modification of the Nafion membrane [205]. However in spite of their high proton conductivities and fuel cell performances, sulfonated statistical copolymers are generally characterized by a high degree of dimensional change and poor durability derived from a poorly connected nonhydrated phase. Alternatively, the SPP-b-PAES (6.5K)-3.0 membrane had been developed by Lee et al[206]. This membrane exhibited high proton conductivity, stable dimensional variation, along with high performance and durability. In June 2013, ACAL Energy Ltd announced that it enabled a PEM hydrogen fuel cell to reach 10,000 h runtime on a third party automotive industry durability test without any significant signs of degradation [206, 207]. 10,000h, the equivalent of 300,000 driven miles, is the point at which hydrogen fuel cell endurance is comparable to the best light - weight diesel engines under such test conditions. This endurance far exceeds the current 2017 US Department of Energy (DOE) industry target for fuel cell powered vehicles to last $5000 \mathrm{~h}$, equivalent to 150,000 road miles, with an expected degradation threshold of approximately $10 \%$. The ACAL Energy company claimed its technology was designed to be different from the conventional fuel cell by not relying on platinum as catalyst for the reaction between oxygen and hydrogen. The liquid acts as both a coolant and catalyst for the cells, ensuring that they last longer by removing most of the known decay mechanisms. As of March 2017, ACAL went into voluntary liquidation [208].

In 2016 annual plan of FCH 2 JU (The Fuel Cell and Hydrogen 2 Joint Undertaking), there is a specific focus on manufacturing technologies of PEMFC for transport applications. It is mentioned that in spite of the maturity level of the PEMFC technology, it is still facing some challenges in many aspects such as manufacturability, production efficiency and production cost. FCH 2JU has dedicated a full project that will investigate the process development of the critical steps of PEMFC stack manufacturing and production of component engineering samples. The intended aim of the project is to increase the production of PEMFC stacks from few 100 stacks per year up to 50,000 stacks per year in 2020. Other conditions such as hydrogen refuelling infrastructure and hydrogen storage in vehicles were discussed in previous sections. 


\section{Conclusion}

The call for fuel cells to be introduced into the transport industry is gradually gaining attention by the automobile industry. The advantages of PEM type fuel cell devices over the traditional ICE continue to make them a better choice for the automobile industry due to their high efficiency and low emissions. This paper charts the recent evolution of electric cars and fuel cell hydrogen electric cars as well as some of the progress made by various car manufacturing companies around the globe. The paper explains some of latest designs of cars on the market that uses this technology with their technical specifications being described in this report. Major challenges impeding the expansion of fuel cells technology in the automobile industry was also carefully examined in this investigation. High cost, low durability, hydrogen refuelling infrastructure and hydrogen storage on fuel cell vehicles play key roles in hampering the expansion of this useful technology in the automobile industry. The mechanical durability is an important performance indicator for fuel cell devices used in transport applications. Cost is a primary factor that seriously discourages the further advancement of this technology. A solution was suggested by lowering the platinum content without degrading the fuel cell performance and finding platinum free catalysts which are very useful for reducing cost of the power generated from fuel cell. This paper study the main challenges faced by using PEM fuel cells in the automobile industry and some latest modifications of the existing technology that are used by the industry to cut down the cost of cars designed to use fuel cells technology for providing power. All the three categories of electric cars were also reviewed and their power conversion technologies were explored. The state of the art FCHEV technologies as well as their future prospects were also accessed. The advantages and disadvantage of each type of electric vehicle were also analysed in details. The work concludes the future of the automobile industry is highly dependent on electric cars but more work still needs to be done by the industry and academic researchers to reduce the overall cost of the ownership of electric cars and to improve the infrastructure necessary to service and maintain them.

With growing car usage in many countries around the world and dwindling reserve of the traditional sources of transport fuels, the necessity to change course and develop new means of powering vehicle is a necessity. Current developments in both vehicle and fuel cells technologies provide a promising solution for the problem. This coupled with sourcing of hydrogen from 
clean renewable sources such as wind or solar energy will lead to a better solution for transportation fuels requirements and cleaner environment. 


\section{References}

1. Tabbi Wilberforce, A. Alaswad, A. Palumbo, A. G. Olabi. Advances in stationary and portable fuel cell applications. International Journal of Hydrogen Energy 41(37) March 2016.

2. Das, S. H., Tan, C, W., Yatim, A. H. M. Fuel cell hybrid electric vehicles: A review on power conditioning units and topologies; 68-291.

3. High Impedance Battery Research. Meridian International Research; 2006.

4. Chau K, Chan C. Emerging energy-efficient technologies for hybrid electric vehicles. In: Proceedings of the IEEE; 2007, 95: 821-35.

5. Baroutaji, A, Carton J. G., Stokes J., Olabi A. G. Application of Open Pore Cellular Foam for air breathing PEM fuel cell. International Journal of Hydrogen Energy (2017). DOI: 10.1016/j.jijhydene.2017.05.114.

6. A. Alaswad, A. Baroutaji, H. Achour, J. Carton, Ahmed Al Makky, A G. Olabi. Developments in fuel cell technologies in the transport sector. International Journal of Hydrogen Energy 41(2016) 16499 - 16508.

7. Tabbi Wilberforce, Ahmed Al Makky, A. Baroutaji, Rubal Sambi, A.G. Olabi. Computational Fluid Dynamic Simulation and modelling (CFX) of Flow Plate in PEM fuel cell using Aluminum Open Pore Cellular Foam Material. Power and Energy Conference (TPEC), IEEE, Texas. 2017. DOI: 10.1109/TPEC.2017.7868285.

8. Saboohi Y, Farzaneh H. Model for developing an eco-driving strategy of a passenger vehicle based on the least fuel consumption. Appl Energy. October 2009; 86(10): 192532.

9. Tabbi Wilberforce, Zaki El-Hassan, Ahmed Al Makyy, F.N. Khatib, A. Baroutaji, J. G. Carton, A. G. Olabi. Modelling and Simulation of Proton Exchange Membrane Fuel cell with Serpentine bipolar plate using MATLAB. International Journal of Hydrogen Energy (2017). DOI: 10.1016/j.ijhydene.2017.06.091

10. Achour H, Olabi AG. Driving cycle developments and their impacts on energy consumption of transportation. J Clean Prod August 2015; 11: 0959-6526.

11. Tabbi Wilberforce, Ahmed Al Makky, A. Baroutaji, Rubal Sambi, A.G. Olabi Optimization of bipolar plate through computational fluid dynamics simulation and modelling using nickle open pore cellular foam material. International conference on 
renewable energies and power quality (ICREPQ'17), ISSN 2171-038X, No 15 April 2017

12. Achour H, Carton JG, Olabi AG. Estimating vehicle emissions from road transport, case study: Dublin City. Appl Energy May 2011; 88(5): 1957-64.

13. US DOD, Fuel cell test and evaluation center. http://www.fctec.com/ (Accessed: 06/07/2017)

14. Colleen, S. S., 2007. Designing and Building Fuel Cells. $1^{\text {st }}$ ed. ISBN 0-7-148977-0

15. Collecting the History of Fuel Cells. http://americanhistory.si.edu/fuelcells/pem/pemmain.htm. (Accessed: 06/07/2017).

16. Tabbi Wilberforce, A. Alaswad, J. Mooney, A. G. Olabi. Hydrogen Production for Solar Energy Storage. A Proposed Design Investigation. Proceedings of the $8^{\text {th }}$ International Conference on sustainable Energy and Environmental Protection. ISBN: 978-1-903978$52-8$.

17. Olabi AG. State of the art on renewable and sustainable energy. Energy 2013; 61: 2-5.

18. Carton, J. G., Olabi, A. G. Representative model and flow characteristics of open pore cellular foam and potential use in proton exchange membrane fuel cells. International Journal Of Hydrogen Energy 40 (2015) 5726 - 5738.

19. Olabi AG. The 3rd international conference on sustainable energy and environmental protection SEEP 2009 the guest editor's introduction. Energy 2010; 35: 4508-9

20. Franco, B., 2012. PEM Fuel Cell. Theory and Practice. $2^{\text {nd }}$ ed. ISBN 9780123877109

21. Mikkola, Mikko. "Experimental Studies on Polymer Electrolyte Membrane Fuel Cell Stacks." Helinski University of Technology, Department of Engineering Physics and Mathematics, Masters Thesis 2001.

22. Lin, Bruce. "Conceptual Design and Modelling of a Fuel Cell Scooter for Urban Asia." Princeton University, Masters Thesis 1999

23. Khaligh Alireza, Li Zhihao. Battery, ultra-capacitor, fuel cell, and hybrid energy storage systems for electric, hybrid electric, fuel cell, and plug-in hybrid electric vehicles: state of the art. 6th July 2010.

24. Cele Nonhlanhla P, Sinha-Ray Suprakas, Munda Josiah, Jimoh Adisa A. The state of the art proton exchange membrane fuel cells for clean energy. 2010. 
25. Carton JG, Olabi AG. Three-dimensional proton exchange membrane fuel cell model: comparison of double channel and open pore cellular foam flow plates. Energy 2016: 1e11. http://dx.doi.org/10.1016/j.energy.2016.02.010 [in press].

26. Olabi AG. Developments in sustainable energy and environmental protection. Energy 2012; 39: 2-5

27. Tawfik H, Hung Y, Mahajan D. Metal bipolar plates for PEM fuel cell: A review. Journal of power sources, volume 163, Issue 2, January 2007, pages 755 - 767. https://doi.org/10.1016/j.jpowsour.2006.09.088

28. Cacciola G, Antonucci V, Freni S. Technology up date and new strategies on fuel cells. 2001.

29. Hermann Allen, Chaudhuria Tapas, Spagnol Priscila. Bipolar plates for PEMfuel cells: a review. 2nd June 2005.

30. Brian James D, Jeffrey Kalinoski A, Baum Kevin. Mass production cost estimation for direct H2 PEM fuel cell system for automotive applications: 2009 update. 1st January 2010.

31. Litster S, McLean G. PEM fuel cell electrodes. 14th December 2003.

32. Lukic SM, Emadi A. Effects of drivetrain hybridization on fuel economy and dynamic performance of parallel hybrid electric vehicles. Veh Technol, IEEE Trans 2004; 53: $385-9$.

33. Voelcker J. EPA says toyota prius hybrid no longer. 'Most Fuel-Efficient' 2011.

34. Alson J, Hula A, Bunker A. Light-duty automotive technology, carbon dioxide emissions, and fuel economy trends: 1975 through 2014. Ann Arbor, Michigan: US Environmental Protection Agency; 2015, Appendix F.

35. Citroën C3 Automobiles Citroën; 2015.

36. Micro-Hybrids To Grow Fast: More Than Start-Stop, Less Than Mild Hybrid. Green Car Reports; 2014.

37. Byykoglu Atilla. Review of proton exchange membrane fuel cell models. 6th July 2005.

38. Costamagna Paola, Srinivasan Supramaniam. Quantum jumps in the PEMFC science and technology from the 1960s to the year 2000 part I. Fundamental scientific aspect. 27th April 2001. 
39. Omar Sharaf Z, Mehmet Orhan F. An overview of fuel cell technology: fundamentals and applications. 13th February 2014.

40. Becker, B (2009). Electric Vehicles in the United States, A new model with forecast to 2030. Centre for Entrepreneurship \& Technology, University of Carlifornia, Berkeley technical brief.

41. Hickman, J. (2009). Clean vehicles, Renewable Energy Focus March/April: 33-34.

42. Bing Li, Hui Li, Jianxin Ma, Haijiang Wang. PEM fuel cells: current status and challenges for electrical vehicle applications. J Automot Saf Energy 2010; 1(4).

43. Harrop, P. and Das, R. (2009) Hybrid and pure electric cars 2009-2019. Research report on

http://www.idtechex.com/research/reports/hybrid_and_pure_electric_cars_2009_2019_00 0227.asp (Accessed: 06/07/2017)

44. Zhang, F., Cooke, P. (2008). Future Prospects and Perspectives on biofuels, working paper for Dynamics of Institutions and Markets in Europe (DIME). , http://www.dimeeu.org/files/active/0/Cooke-08-Fang-Biofuels-up.pdf. (Accesses: 06/07/2017).

45. J.G. Carton and A.G. Olab, "Design of experiment study of the parameters that affect performance of three flow plate configurations of a proton exchange membrane fuel cell”, Energy, 35 (7), pp 2796-2806, 2010.

46. Eberle, U., Rittmar von Helmolt, 2010. Fuel Cell Electric Vehicles, Battery Electric Vehicles, and their Impact on Energy Storage Technologies: An Overview. ISBN 978-0$444-53565-8$

47. Tie SF, Tan CW. A review of energy sources and energy management system in electric vehicles. Renew Sustain Energy Rev 2013; 20: 82-102.

48. Chan C. The state of the art of electric, hybrid, and fuel cell vehicles. In: Proceedings of the IEEE, vol. 95; 2007. p. 704-18.

49. Li X, Williamson, SS. Assessment of efficiency improvement techniques for future power electronics intensive hybrid electric vehicle drive trains. In: Proceedings of Electrical Power Conference, 2007 EPC 2007 IEEE Canada: IEEE; 2007. p. 268- 73.

50. Emadi A, Rajashekara K. Power electronics and motor drives in electric, hybrid electric, and plug-in hybrid electric vehicles. IEEE Trans Ind Electron 2008; 55: 2237-45. 
51. Momoh OD, Omoigui MO. An overview of hybrid electric vehicle technology. In: Proceedings of vehicle power and propulsion conference, 2009 VPPC'09 IEEE: IEEE; 2009. p. 1286-92.

52. R. Bady, J.W. Biermann, B. Kaufmann, H. Hacker, European Electric Vehicle Fleet Demonstration with ZEBRA Batteries, SAE 1999-01-1156.

53. Palmeri, C. \& Carey, J. (2009) Electric Connection: Tesla, Daimler, Business Week, dated on 19/05/2016

54. Madslien, J. (2009) The future of electric motoring, BBC News. http://news.bbc.co.uk/1/mobile/business/8001667.stm. (Accessed: 06/07/2017)

55. Tesla, 2016. https: //www.tesla.com/en_GB/models (accessed: 26/12/2016)

56. Greene, D., Leiby, P., James, B., Perez, J., Melendez, M., Milbrandt, A., Unnasch, S. and Hooks, M. (2008) Transition to hydrogen fuel cell vehicles \& the potential hydrogen energy infrastructure requirements. In Selim Koca (Editor). Transition to Hydrogen Fuel Cell Vehicles. 2011. Nova Science Publishers Inc.

57. T. Johnen, R. von Helmolt, U. Eberle, Conference Proceedings Volume of the Technischer Kongress 2009, German Automotive Industry Association VDA.

58. Pesaran AA, Gonder JD, Keyser M. Ultra-capacitor applications and evaluation for hybrid electric vehicles. National Renewable Energy Laboratory; 2009.

59. Chan C-C, Bouscayrol A, Chen K. Electric, hybrid, and fuel-cell vehicles: architectures and modeling. Veh Technol, IEEE Trans 2010; 59: 589-98.

60. Forbes (2009) Metso's Valmet to start making Think electric car, forbes.com, dated on: http: //www.forbes.com/feeds/afx/2009/08/27/afx6821773.html (accessed: 26/12/2016)

61. Moulson, G. \& Moore, M. (2009) Germany jumps in the race of viable electric car, Google news, dated on 19/08/2009.

62. Toyota, 2016. How hybrid cars work. https: //www.toyota.co.uk/hybrid/how-hybridworks (Accessed: 26/12/2016)

63. Uzunoglu M, Alam MS. Dynamic modeling, design and simulation of a PEM fuel cell/ultra-capacitor hybrid system for vehicular applications. Energy Convers Manag 2007; 48: 1544-53.

64. Mekhilef S, Saidur R, Safari A. Comparative study of different fuel cell technologies. Renew Sustain Energy Rev 2012; 16: 981-9. 
65. T. Johnen, R. von Helmolt, U. Eberle, Conference Proceedings Volume of the Technischer Kongress 2009, German Automotive Industry Association VDA.

66. C. Marks, E.A. Rishavy, F.A. Wyczalek, SAE Congress, January 1967, Detroit, USA, paper 670176.

67. Emadi A, Williamson SS, Khaligh A. Power electronics intensive solutions for advanced electric, hybrid electric, and fuel cell vehicular power systems. Power Electron, IEEE Trans 2006; 21: 567-77.

68. Al Sakka M, Van Mierlo J, Gualous H. DC/DC converters for electric vehicles. Electr Veh-Model Simul 2011: 309.

69. Beaudin M, Zareipour H, Schellenberglabe A, Rosehart W. Energy storage for mitigating the variability of renewable electricity sources: an updated review. Energy Sustain Dev 2010; 14: 302-14.

70. Baker J. New technology and possible advances in energy storage. Energy Policy 2008; 36: $4368-73$.

71. Westbrook MH. The electric and hybrid electric car. London, United Kingdom: SAE The Institution of Electrical Engineers; 2001.

72. Mikkelsen K. Design and evaluation of hybrid energy storage systems for electric powertrains. Waterloo, Ontario: University of Waterloo; 2010.

73. Jaguemont J, Boulon L, Dubé Y. A comprehensive review of lithium-ion batteries used in hybrid and electric vehicles at cold temperatures. Appl Energy 2016; 164: 99-114.

74. Hopkins, S. (2009) Green Chip Stocks. https://www.greenchipstocks.com/videos/samhopkins-on-wind-energy-from-brazil/57 (Accessed: 08/07/2017)

75. Burke A. Ultra-capacitors: why, how, and where is the technology. J Power Sources 2000; 91: 37-50.

76. Conway BE. Electrochemical supercapacitors scientific fundamentals and technological applications. New York: Kluwer Academic/Plenum Publishers; 1999.

77. Samborsky SJ. Design and Simulation of an Ultra-capacitor-Based Hybrid Electric Vehicle: University of Waterloo; 2006.

78. Husain I. Electric and hybrid vehicles: design fundamentals. CRC press; 2011.

79. Burke A. Ultra-capacitor technologies and application in hybrid and electric vehicles. Int J Energy Res 2010; 34: 133-51. 
80. Halper MS, Ellenbogen JC. Supercapacitors: a brief overview. McLean, Virginia: The MITRE Corporation; 2006, Report No. MP 05W0000272.

81. Hadjipaschalis I, Poullikkas A, Efthimiou V. Overview of current and future energy storage technologies for electric power applications. Renew Sustain Energy Rev 2009; 13: 1513-22.

82. Schneuwly A, Gallay R. Properties and applications of supercapacitors: From the stateof-the-art to future trends. Rossens, Switzerland; 2000. https://www.garmanage.com/atelier/root/public/Contacting/biblio.cache/PCIM2000.pdf (Accessed: 07/07/2017)

83. González A, Goikolea E, Barrena JA, Mysyk R. Review on supercapacitors: technologies and materials. Renew Sustain Energy Rev 2016; 58: 1189-206.

84. R. von Helmolt, U. Eberle, Hydrogen Technology, A. Leon (Ed.), Springer, 2008, pp. 273-290

85. Fangzhu, Z., \& Philip, C. (2009). The Green Vehicle Trend: Electric, Plug - in hybrid or Hydrogen fuel cell? Centre for Advanced Studies, Cardiff University. http: //www.dimeeu.org/files/active/0/Cooke-09-Fang-Green-vehicle-Review.pdf (Accessed: 27/12/2016)

86. Ahn, B. \& Lim, T. (2006) Fuel cell vehicle development at Hyundai-Kai Motors, IEEE, 18-20th Oct., 199-201.

87. Fact Sheet Frequency Regulation and Flywheels; 2010.

88. Climate Tech Wiki; 2011.

89. Ehsani M, Gao Y, Emadi A. Modern electric, hybrid electric, and fuel cell vehicles: fundamentals, theory, and design. CRC press; 2009.

90. Li X, Williamson, SS. Assessment of efficiency improvement techniques for future power electronics intensive hybrid electric vehicle drive trains. In: Proceedings of Electrical Power Conference, 2007 EPC 2007 IEEE Canada: IEEE; 2007. p. 268- 73.

91. X-k CHEN, S-q TANG. Research on the application of the stand-alone wind power system with a newtype of flywheel energy storage battery. Energy Conserv 2005; 1: 225.

92. Liu H, Jiang J. Flywheel energy storage-an upswing technology for energy sustainability. Energy Build 2007; 39: 599-604. 
93. Arani AAK, Karami H, Gharehpetian GB, Hejazi MSA. Review of Flywheel Energy Storage Systems structures and applications in power systems and microgrids. Renew Sustain Energy Rev 2017; 69: 9-18.

94. Emadi A, Williamson SS. Fuel cell vehicles: opportunities and challenges. In: Proceedings of power engineering society general meeting, 2004 IEEE. Denver, CO: IEEE; 2004. p. 1640-5.

95. Tazelaar E, Veenhuizen B, Jagerman J, Faassen T. Energy management strategies for fuel cell hybrid vehicles; an overview. In: Proceedings of electric vehicle symposium and exhibition (EVS27), 2013 World Barcelona, Spain: IEEE; 2013. p. 1-12.

96. Azib T, Bethoux O, Remy G, Marchand C, Berthelot E. An innovative control strategy of a single converter for hybrid fuel cell/supercapacitor power source. Ind Electron, IEEE Trans 2010; 57: 4024-31.

97. Li Q, Chen W, Li Y, Liu S, Huang J. Energy management strategy for fuel cell/ battery/ultra-capacitor hybrid vehicle based on fuzzy logic. Int J Electr Power Energy Syst 2012; 43: 514-25.

98. Mallouh MA, Surgenor B, Dash P, McInnes L. Performance evaluation and tuning of a fuzzy control strategy for a fuel cell hybrid electric auto rickshaw. In: Proceedings of American Control Conference; 2012 IEEE Fairmont, Canada. p. 1321-6.

99. Tazelaar E, Veenhuizen B, Den Bosch PV, Grimminck M. Analytical solution of the energy management for fuel cell hybrid propulsion systems. IEEE Trans Veh Technol 2012; 61: 1986-98.

100. Wang L, Wang Z, Li H. Optimized energy storage system design for a fuel cell vehicle using a novel phase shift and duty cycle control. In: Proceedings of IEEE Energy Conversion Congress and Exposition, 2009 ECCE; 2009. p. 1432-8.

101. Payman A, Pierfederici S, Meibody-Tabar F. Energy management in a fuel cell/ supercapacitor multisource/multiload electrical hybrid system. Power Electron, IEEE Trans 2009; 24: 2681-91.

102. Kisacikoglu M, Uzunoglu M, Alam M. Load sharing using fuzzy logic control in a fuel cell/ultra-capacitor hybrid vehicle. Int J Hydrog Energy 2009; 34: 1497-507. 
103. Hegazy O, Van Mierlo J, Lataire P. Design optimization and optimal power control of fuel cell hybrid electric vehicles based on swarm intelligence. Int Rev Electr Eng 2011; 6: $1727-38$.

104. Hegazy O, Van Mierlo J. Particle swarm optimization for optimal powertrain component sizing and design of fuel cell hybrid electric vehicle. In: Proceedings of 12th IEEE international conference on optimization of electrical and electronic equipment (OPTIM); 2010. p. 601-9.

105. Zheng C, Oh C, Park Y, Cha S. Fuel economy evaluation of fuel cell hybrid vehicles based on equivalent fuel consumption. Int J Hydrog Energy 2012; 37: 1790-6.

106. Zheng C, Park Y, Lim W, Cha S. Fuel economy evaluation of fuel cell hybrid vehicles based on optimal control. Int J Autom Technol 2012; 13: 517-22.

107. Gao D, Jin Z, Lu Q. Energy management strategy based on fuzzy logic for a fuel cell hybrid bus. J Power Sources 2008; 185: 311-7.

108. Odeim F, Roes J, Heinzel A. Power management optimization of an experimental fuel cell/battery/supercapacitor hybrid system. Energies 2015; 8: 6302-27.

109. Erdinc O, Vural B, Uzunoglu M. A wavelet-fuzzy logic based energy management strategy for a fuel cell/battery/ultra-capacitor hybrid vehicular power system. J Power Sources 2009; 194: 369-80.

110. Melero-Pérez A, Gao W, Fernández-Lozano JJ. Fuzzy Logic energy management strategy for Fuel Cell/Ultra-capacitor/Battery hybrid vehicle with multiple-input DC/DC converter. In: Proceedings of vehicle power and propulsion conference, 2009 VPPC'09 IEEE; 2009. p. 199-206.

111. Yu Z, Zinger D, Bose A. An innovative optimal power allocation strategy for fuel cell, battery and supercapacitor hybrid electric vehicle. J Power Sources 2011; 196: 2351-9.

112. Li C-Y, Liu G-P. Optimal fuzzy power control and management of fuel cell/battery hybrid vehicles. J Power Sources 2009; 192: 525-33.

113. Xiao D, Wang Q. The research of energy management strategy for fuel cell hybrid vehicle. IEEE. p. 931-4. 
114. Xie C-j, Quan S-h, Chen Q-h. Control strategy of hybrid power system for Fuel Cell Electric Vehicle based on neural network optimization. In: Proceedings of IEEE international conference on automation and logistics, 2008 ICAL; 2008. p. 753-7.

115. Hong-wen H, Ying-qi Z, Fan W. Control strategies design for a fuel cell hybrid electric vehicle. In: Proceedings of IEEE vehicle power and propulsion conference, 2008 VPPC'08 IEEE; 2008. p. 1-6.

116. Shuang Y, Junzhi Z, Lifang W. Power management strategy with regenerative braking for fuel cell hybrid electric vehicle. In: Proceedings of Asia-Pacific power and energy engineering conference, APPEEC 2009: IEEE; 2009. p. 1-4.

117. Xiao D, Qi W, Jin H, Fang J. Modeling and simulation for golf fuel cell electric vehicle control system. In: Proceedings of IEEE spring congress on engineering and technology (SCET); 2012. p. 1-4.

118. Li X, Xu L, Hua J, Li J, Ouyang M. Regenerative braking control strategy for fuel cell hybrid vehicles using fuzzy logic. In: Proceedings of IEEE international conference on electrical machines and systems, 2008 ICEMS; 2008. p. 2712-6.

119. Payman A, Pierfederici S, Meibody-Tabar F. Energy management in a fuel cell/ supercapacitor multisource/multiload electrical hybrid system. IEEE Trans Power Electron 2009; 24: 2681-91.

120. Ouddah N, Boukhnifer M, Raisemche A. Two control energy management schemes for electrical hybrid vehicle. In: Proceedings of 10th IEEE international multi-conference on systems, signals \& devices (SSD); 2013. p. 1-6.

121. Sundström O, Stefanopoulou A. Optimal power split in fuel cell hybrid electric vehicle with different battery sizes, drive cycles, and objectives. In: Proceedings of computer aided control system design, 2006 IEEE international conference on control applications, 2006 IEEE international symposium on intelligent control, 2006 IEEE; 2006. p. 1681-8.

122. Karunarathne L, Economou JT, Knowles K. Model based power and energy management system for PEM fuel cell/Li-Ion battery driven propulsion system. In: Proceedings of 5th IET international conference on power electronics, machines and drives (PEMD 2010); 2010. p. 1-6. 
123. Alloui $\mathrm{H}$, Becherif $\mathrm{M}$, Marouani $\mathrm{K}$. Modelling and frequency separation energy management of fuel cell-battery hybrid sources system for Hybrid Electric Vehicle. In: Proceedings of 21st mediterranean conference on control \& automation (MED), IEEE; 2013. p. 646-51.

124. Kelouwani S, Agbossou K, Dubé Y, Boulon L. Fuel cell Plug-in Hybrid Electric Vehicle anticipatory and real-time blended-mode energy management for battery life preservation. J Power Sources 2013; 221: 406-18.

125. Benrabeh A, Khoucha F, Herizi O, Benbouzid M, Kheloui A. FC/battery power management for electric vehicle based interleaved DC-DC boost converter topology. In: Proceedings of 15th European conference on power electronics and applications (EPE), IEEE; 2013. p. 1-9.

126. Thounthong P, Pierfederici S, Martin J-P, Hinaje M, Davat B. Modeling and control of fuel cell/supercapacitor hybrid source based on differential flatness control. Veh Technol, IEEE Trans 2010; 59: 2700-10.

127. Tani A, Camara MB, Dakyo B, Azzouz Y. DC/DC and DC/AC converters control for hybrid electric vehicles energy management-ultra-capacitors and fuel cell. Ind Inform, IEEE Trans 2013; 9: 686-96.

128. Uzunoglu M, Alam M. Modeling and analysis of an FC/UC hybrid vehicular power system using a novel-wavelet-based load sharing algorithm. Energy Convers, IEEE Trans 2008; 23: 263-72.

129. Efstathiou D, Petrou A, Spanoudakis P, Tsourveloudis N, Valavanis K. Recent advances on the energy management of a Hybrid Electric vehicle. In: Proceedings of 20th mediterranean conference on control \& automation (MED): IEEE; 2012. p. 896-901.

130. Rodatz P, Paganelli G, Sciarretta A, Guzzella L. Optimal power management of an experimental fuel cell/supercapacitor-powered hybrid vehicle. Control Eng Pract 2005; 13: $41-53$. 
131. Ates Y, Uzunoglu M, Erdinc O, Vural B. A wavelet-ADALINE network based load sharing and control algorithm for a FC/UC hybrid vehicular power system. In: Proceedings of IEEE international conference on clean electrical power; 2009. p. 591-4.

132. Zheng C-H, Lee C-M, Huang Y-C, Lin W-S. Adaptive optimal control algorithm for maturing energy management strategy in fuel-cell/Li-ion-capacitor hybrid electric vehicles. In: Proceedings of 9th IEEE Asian control conference (ASCC); 2013. p. 1-7.

133. Martínez JS, Hissel D, Péra M-C, Amiet M. Practical control structure and energy management of a testbed hybrid electric vehicle. Veh Technol, IEEE Trans 2011; 60: 413952.

134. Motapon SN, Dessaint L, Al-Haddad K. A comparative study of energy management schemes for a fuel-cell hybrid emergency power system of more-electric aircraft. Ind Electron, IEEE Trans 2014; 61: 1320-34.

135. Hannan M, Azidin F, Mohamed A. Multi-sources model and control algorithm of an energy management system for light electric vehicles. Energy Convers Manag 2012; 62: $123-30$.

136. García P, Torreglosa JP, Fernández LM, Jurado F. Control strategies for high power electric vehicles powered by hydrogen fuel cell, battery and supercapacitor. Exp Syst Appl 2013; 40: 4791-804.

137. Paladini V, Donateo T, De Risi A, Laforgia D. Super-capacitors fuel-cell hybrid electric vehicle optimization and control strategy development. Energy Convers Manag 2007; 48: $3001-8$.

138. Zandi M, Payman A, Martin J-P, Pierfederici S, Davat B, Meibody-Tabar F. Energy management of a fuel cell/supercapacitor/battery power source for electric vehicular applications. Veh Technol, IEEE Trans 2011; 60: 433-43.

139. Liu X, Diallo D, Marchand C. Design methodology of fuel cell electric vehicle power system. In: Proceedings of 18th IEEE international conference on electrical machines, 2008 ICEM; 2008. p. 1-6. 
140. Florescu A, Stocklosa O, Teodorescu M, Radoi C, Stoichescu D, Rosu S. The advantages, limitations and disadvantages of Z-source inverter. In: Proceedings of semiconductor conference (CAS 2010); 2010. p. 483-6.

141. Biel D, Guinjoan F, Fossas E, Chavarria J. Sliding-mode control design of a boost buck switching converter for AC signal generation. Circuits Syst I: Regul Pap, IEEE Trans 2004; 51: 1539-51.

142. Shen M, Joseph A, Wang J, Peng FZ, Adams DJ. Comparison of traditional inverters and Z-source inverter for fuel cell vehicles. Power Electron, IEEE Trans 2007; 22: 1453-63.

143. Peng FZ, Shen M, Holland K. Application of Z-source inverter for traction drive of fuel cell-battery hybrid electric vehicles. Power Electron, IEEE Trans 2007; 22: 1054-61.

144. Peng FZ. Z-source inverter. Ind Appl, IEEE Trans 2003; 39: 504-10.

145. Sanchis P, Ursæa A, Gubía E, Marroyo L. Boost DC-AC inverter: a new control strategy. Power Electron, IEEE Trans 2005; 20: 343-53.

146. Tan G-H, Zeng F, Ji Y, Chen X, Wang H. Novel single-stage isolated buck-boost inverter based on improved SPWM control method. In: Proceedings of 5th IEEE international power electronics and motion control conference, IPEMC 2006 CES/ IEEE; 2006. p. 1-5.

147. Cortes D, Vázquez N, Alvarez-Gallegos J. Dynamical sliding-mode control of the boost inverter. Ind Electron, IEEE Trans 2009; 56: 3467-76.

148. Caceres R, Barbi I. Sliding mode controller for the boost inverter. Power Electronics Congress, 1996 Technical Proceedings CIEP'96, V IEEE International: IEEE; 1996. p. 24752.

149. Cáceres R, Barbi I. A boost DC-AC converter: operation, analysis, control and experimentation. In: Proceedings of the IEEE IECON 21st international conference on industrial electronics, control, and instrumentation; 1995. p. 546-51.

150. Caceres RO, Barbi I. A boost DC-AC converter: analysis, design, and experiment Power Electron, IEEE Trans 1999; 14: 134-41.

151. Caceres RO, Garcia WM, Camacho OE. A buck-boost DC-AC converter: operation, analysis, and control. In: Proceedings of VI IEEE international power electronics congress; 1998. p. 126-131. 
152. Sanchis P, Gubía E, Marroyo L. Design and experimental operation of a control strategy for the buck-boost DC-AC inverter. Electr Power Appl, IEE Proc: IET 2005: 660-8.

153. Sanchis P, Alonso O, Marroyo L, Meynard T, Lefeuvre E. A new control strategy for the boost DC-AC inverter. In: Proceedings of 32nd IEEE annual power electronics specialists conference, PESC 2001; 2001. p. 974-9.

154. Sanchis P, Alonso O, Marroyo L. Variable operating point robust control strategy for boost converters. In: Proceedings of 9th European conference on power electronics applications (EPE'01); 2001 p. 27-9.

155. Jang M, Ciobotaru M, Agelidis VG. A single-phase grid-connected fuel cell system based on a boost-inverter. Power Electron, IEEE Trans 2013; 28: 279-88.

157. Jang M, Agelidis VG. A minimum power-processing-stage fuel-cell energy system Electron, IEEE Trans 2011; 26: 1568-77.

158. Jang M, Agelidis VG. Grid-interfaced fuel cell energy system based on a boost inverter with a bi-directional back-up battery storage. In: Proceedings of IEEE energy conversion congress and exposition (ECCE); 2010. p. 4499-506.

159. Jang M, Ciobotaru M, Agelidis V. A single-stage fuel cell energy system based on a buck-boost inverter with a back-up unit. Power Electronics and ECCE Asia (ICPE \& ECCE), 2011 IEEE 8th International Conference on: IEEE; 2011. p. 1894- 1900.

160. Jang M, Ciobotaru M, Agelidis V. Grid-connected fuel cell system based on a boostinverter with a battery back-up unit. In: Proceedinngs of 8th international conference on power electronics and ECCE Asia (ICPE \& ECCE), 2011 IEEE; 2011. p. 1637-44.

161. Jang M, Ciobotaru M, Agelidis VG. A single-stage fuel cell energy system based on a buck-boost inverter with a backup energy storage unit. Power Electron, IEEE Trans 2012; 27: 2825-34.

162. Jang M, Ciobotaru M, Agelidis VG. A single-stage three-phase fuel cell system based on a boost inverter with a battery back-up unit. In: Proceedings of twenty seventh annual IEEE applied power electronics conference and exposition.

163. Danyali S, Hosseini SH, Gharehpetian GB. New extendable single-stage multi input DC-DC/AC boost converter. Power Electron, IEEE Trans 2014; 29: 775-88.

164. Tang Y, Yao W, Blaabjerg F. A dual mode operated boost inverter and its control strategy for ripple current reduction in single-phase uninterruptible power supplies. In: 
Proceedings of 9th IEEE international conference on power electronics and ECCE Asia (ICPE-ECCE Asia); 2015. p. 2227-34.

165. Moraka O, Barendse P, Khan MA. Dead time effect on the double loop control strategy for a boost inverter. IEEE Trans Ind Appl 2016.

166. Wai R-J, Chen M-W, Liu Y-K. Design of adaptive control and fuzzy neural network control for single-stage boost inverter. IEEE Trans Ind Electron 2015; 62: 5434-45.

167. Danyali S, Mozaffari Niapour SAK, Hosseini SH, Gharehpetian GB, Sabahi M. New single-stage single-phase three-input DC-AC boost converter for stand-alone hybrid PV/FC/UC systems. Electr Power Syst Res 2015; 127: 1-12.

168. Jha K, Mishra S, Joshi A. High-quality sine wave generation using a differential boost inverter at higher operating frequency. Ind Appl, IEEE Trans 2015; 51: 373-84.

169. Wai R-J, Lin Y-F, Liu Y-K. Design of adaptive fuzzy-neural-network control for a single-stage boost inverter. IEEE Trans Power Electron 2015; 30: 7282-98.

170. Abeywardana DBW, Hredzak B, Agelidis VG. An input current feedback method to mitigate the DC-side low-frequency ripple current in a single-phase boost inverter. IEEE Trans Power Electron 2016; 31: 4594-603.

171. Greene, D., Leiby, P., James, B., Perez, J., Melendez, M., Milbrandt, A., Unnasch, S. and Hooks, M. (2008) Transition to hydrogen fuel cell vehicles \& the potential hydrogen energy infrastructure requirements, ORNL/TM-2008/30, online available on 01/12/2016: http://cta.ornl.gov/cta/Publications/Reports/ORNL_TM_2008_30.pdf.(Accessed: 06/07/2017)

172. Wang Junye. Barriers of scaling-up fuel cells: cost, durability and reliability. Energy 2015; 80: 509-21

173.Marcinkoski J, James BD, Kalinoski JA, Podolski W, Benjamin T, Kopasz J. Manufacturing process assumptions used in fuel cell system cost analyses. J Power Sources 2011; 196(12): 5282-92

174. Odeh AO, Osifo P, Noemagus H.Chitosan: a low costmaterial for the production ofmembrane for use in PEMFCea review. Energy Sources, Part A Recovery, Util Environ Eff 2013; 35(2): 152-63. 
175. Sun Y, Delucchi M, Ogden J. The impact of widespread deployment of fuel cell vehicles on platinum demand and price. Int J Hydrogen Energy 2011; 36(17): 11116-27.

176. Alaswad A, Palumbo A, Dassisti M, Olabi AG. PEM fuel cell cost analysis during the period. In: Accepted in reference module in materials science and materials engineering (MATS). All rights reserved: 2016 Elsevier Inc; 1998-2014.

177. Baroutaji A, Carton JG, Sajjia M, Olabi AG. Materials in PEM fuel cell. In: Saleem Hashmi (editor - in chief), Reference Module in Materials Science and Materials Engineering. Oxford: Elsevier 2016. pp. 1 - 11. ISBN: 978-0-12-8035818.

178. Gasteiger HA, Markovic N, Ross PN, Cairns EJ. Methanol electrooxidation on wellcharacterized platinum-ruthenium bulk alloys. J Phys Chem Nov. 1993; 97(46): 12020-9.

179. Long JW, Stroud RM, Swider-Lyons KE, Rolison DR. How to make electrocatalysts more active for direct methanol oxidation avoid PtRu bimetallic alloys. J Phys Chem B Oct. 2000; 104(42): 9772-6

180. Costamagna Paola, Srinivasan Supramaniam. Quantum jumps in the PEMFC science and technology from the 1960s to the year 2000 part I. Fundamental scientific aspects. J Power Sources 2001; 102:242 -52.

181.Kalyvas C., T Mason, C. Gibbs, D. Brett and A. Kucernak (2014). The Flexi Planar Fuel Cell. USES Conf. Proc. 01 (2014); doi: 10.15445/01012014.138

182.Bae SJ, Kim S-J, Lee J-H, Song I, Kim N-I, Seo Y, et al. Degradation pattern prediction of a polymer electrolyte membrane fuel cell stack with series reliability structure via durability data of single cells. Appl Energy 2014; 131: 48-55.

183.B1yıkoglu Atilla. Review of proton exchange membrane fuel cell models. 6th July 2005.

184.Baroutaji A, Carton JG, Olabi AG, stokes J. Design and development of proton exchange membrane fuel cell using open pore cellular foam as flow plate material. J Energy Chall Mech 2014; 1(2). Article 7

185.Carton JG, Baroutaji A. Developments of foam materials for fuel cell technology. In: Accepted for publication in reference module in materials science and materials engineering; 2016.

186.Wang H. Stainless steel as bipolar plate material for polymer electrolyte membrane fuel cells. J Power Sources Apr. 2003; 115(2): 243-51 
187.Hermann A, Chaudhuri T, Spagnol P. Bipolar plates for PEM fuel cells: a review. Int J Hydrogen Energy Sep. 2005; 30(12): 1297-302

188.Pozio A, Silva RF, De Francesco M, Giorgi L. Nafion degradation in PEFCs from end plate iron contamination. Electrochim Acta May 2003; 48(11): 1543-9

189.Antunes RA, Oliveira MCL, Ett G, Ett V. "Corrosion of metal bipolar plates for PEM fuel cells: a review. Int J Hydrogen Energy Apr. 2010; 35(8): 3632-47.

190.Mehta V, Cooper JS. Review and analysis of PEM fuel cell design and manufacturing. J Power Sources Feb. 2003; 114(1): 32-53.

191.Joseph S, Mcclure J, Chianelli R, Pich P, Sebastian P. Conducting polymer-coated stainless steel bipolar plates for proton exchange membrane fuel cells (PEMFC). Int J Hydrogen Energy Sep. 2005; 30(12): 1339-44.

192.Show Y. Electrically conductive amorphous carbon coating on metal bipolar plates for PEFC. Surf Coat Technol Dec. 2007; 202(4e7): 1252-5

193.Mawdsley JR, Carter JD, Wang X, Niyogi S, Fan CQ, Koc R, et al. "Composite-coated aluminum bipolar plates for PEM fuel cells. J Power Sources Jun. 2013; 231: 106-12.

194.Fu Y, Hou M, Xu H, Hou Z, Ming P, Shao Z, et al. Agepolytetrafluoroethylene composite coating on stainless steel as bipolar plate of proton exchange membrane fuel cell. J Power Sources Aug. 2008; 182(2): 580-4.

195.Hentall PL, Lakeman JB, Mepsted GO, Adcock PL, Moore JM. New materials for polymer electrolyte membrane fuel cell current collectors. J Power Sources Jul. 1999; 80(1e2): 235-41

196.Zhang L, Duan L, Guo Z, Wang J, Zhao K, Tuan W, et al. TiNcoated titanium as the bipolar plate for PEMFC by multi-arc ion plating. Int J Hydrog Energy 2011; 36: 9155e61. SRC - G

197.Ren Z, Zhang D, Wang Z. Stacks with TiN/titanium as the bipolar plate for PEMFCs. Energy Dec. 2012; 48(1): 577-81

198.Cho EA, Jeon U-S, Hong S-A, Oh I-H, Kang S-G. Performance of a 1kW-class PEMFC stack using TiN-coated 316 stainless steel bipolar plates. J Power Sources Mar. 2005; 142(1e2): 177-83. 
199.Hung Y, Tawfik H, Mahajan D. Durability and characterization studies of polymer electrolyte membrane fuel cell's coated aluminum bipolar plates and membrane electrode assembly. J Power Sources Jan. 2009; 186(1): 123-7.

200. Yang L, Yu H, Jiang L, Zhu L, Jian X, Wang Z. Improved anticorrosion properties and electrical conductivity of $316 \mathrm{~L}$ stainless steel as bipolar plate for proton exchange membrane fuel cell by lower temperature chromizing treatment. J Power Sources May 2010; 195(9): 2810-4

201.Wang H, Turner JA. SnO2: F coated ferritic stainless steels for PEM fuel cell bipolar plates. J Power Sources Jul. 2007; 170(2): 387-94

202.Wang H, Turner JA, Li X, Bhattacharya R. "SnO2: F coated austenite stainless steels for PEM fuel cell bipolar plates. J Power Sources Sep. 2007; 171(2): 567-74.

203.U.S. Department of Energy. Pathways to commercial success: technologies and products supported by the fuel cell technologies program. September 2011

204.Choi Hyun-Jung, Jung Sun-Min, Seo Jeong-Min, Chang Dong Wook, Dai Liming, Baek Jong-Beom. Graphene for energy conversion and storage in fuel cells and supercapacitors. Nano Energy 2012; 1: 534-51

205.Jon P. Owejan, Jeffrey J. Gagliardo, Jacqueline M. Sergi and Thomas A. Trabold. Two phase flow consideration in PEMFC design and operation. Proceedings of the sixth international ASME conference on nanochannels, microchannels and minichannels ICNMM2008 June 23-25, 2008, Darmstadt, Germany.

206.Lee Jang Yong, Yu Duk Man, Kim Tae-Ho, Yoon Sang Jun, Hong Young Taik. Multiblock copolymers based on poly(phenylene)s with excellent durability and fuel cell performance. J Membr Sci 2015; 492: 209-19.

207. Greenfleet.net. ACAL Energy hydrogen fuel cell reaches conventional engine durability.http://www.greenfleet.net/news/28062013/acal-energy-hydrogen-fuel-cellreaches-conventional-engine-durability (Accessed: 06/07/2017).

208. The Gazette. https://www.thegazette.co.uk/notice/2739651/ (Accessed: 06/07/2017). 